RAFAEL URBANEJA SANCHEZ

SBI-IFUSP

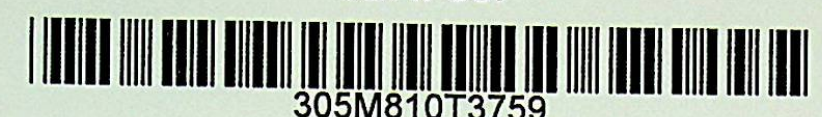

\title{
GRUPOS OPERATIVOS DE APRENDIZAGEM: UMA PERSPECTIVA DE MUDANÇA PARA A RELAÇÃO ENSINO APRENDIZAGEM
}

Dissertação apresentada ao Instituto de Física da Universidade de São Paulo, para a obtenção do grau de Mestre em Ensino de Ciências - modalidade Física. Orientador: Prof. Dr. Alberto Villani

Banca examinadora:

Prof. Dr. Alberto Villani
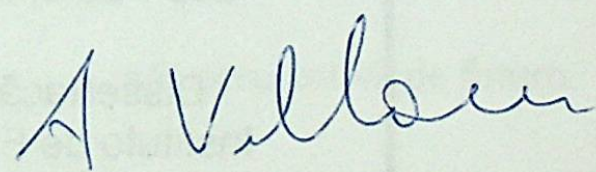
Prof ${ }^{a}$ Dr ${ }^{2}$. Jesuína Lopes de Almeida Pacca Prof ${ }^{a}$. Dr ${ }^{2}$. Maria Helena Trench Ciampone
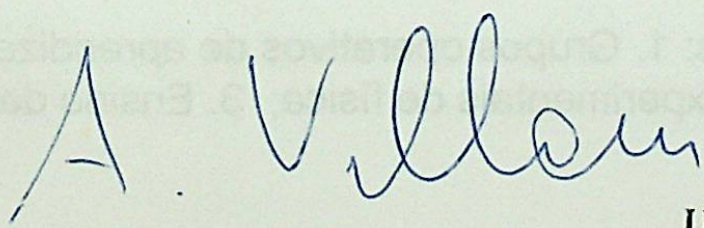

Prof. ${ }^{\circ}$ Alberto Villani Presidente da Comissão de Pós-Graduação Interunidades. INSTITUTO DE FÍSICA Serviço de Biblioteca e Informação Universidade de São Paulo São Paulo - 2002 
FICHA CATALOGRÁFICA

Preparada pelo Serviço de Biblioteca e Informação do Instituto de Física da Universidade de São Paulo

Sanchez, Rafael Urbaneja

"Grupos operativos de aprendizagem: uma perspectiva de mudança para a relação ensino aprendizagem".

São Paulo, 2003

Dissertação (Mestrado) Universidade de São Paulo Instituto de Física. Departamento de Física Aplicada.

Orientador: Prof. Dr. Alberto Villani

Área de Concentração: Ensino-Aprendizagem

Unitermos: 1. Grupos operativos de aprendizagem; 2. Cursos experimentais de física; 3 . Ensino de física. 


\section{DEDICATÓRIA}

Aos meus pais,

pelo apoio constante.

Ao meu filho,

pela perspectiva de futuro.

À minha companheira, pela compreensão no presente. 


\section{AGRADECIMENTOS}

Agradeço a todos que, direta ou indiretamente, contribuíram para a realização deste trabalho, com uma menção especial a todos os alunos que participaram como sujeitos dessa pesquisa.

Meu especial agradecimento a meu orientador que, mesmo diante das dificuldades, esteve sempre presente. 


\section{SUMÁRIO}

LISTA DE ILUSTRAÇÕES.

RESUMO

X

ABSTRACT

$\mathrm{xi}$

RESUMEN xii

1. INTRODUÇÃO: UMA APROXIMAÇÃO AOS PROBLEMAS NA RELAÇÃO ENSINO/APRENDIZAGEM.

1.1.INTRODUÇÃO.

2. O UNIVERSO DA PESQUISA

2.1. O PERFIL DAS ESCOLAS

2.2. O PERFIL DOS ALUNOS .5

2.2.1. Os alunos da Escola 1 5

2.2.1.1. A fase de "diagnóstico" aplicada aos alunos da Escola 1 .6

2.2.2. Os alunos da Escola 2 .7

2.2.2.1. A fase de "diagnóstico" aplicada aos alunos da Escola 2 .8

2.3. UMA TENTATIVA DE IDENTIFICAR A ORIGEM DOS PROBLEMAS NA RELAÇÃO PEDAGÓGICA ENSINO/APRENDIZAGEM

2.3.1. Os grupo de alunos. 9

2.3.1.1. Composição do grupo de alunos. 9

2.3.1.2. O resultado da aplicação do questionário aos alunos 9

2.3.1.3. A análise preliminar das respostas ao questionário aplicado aos alunos

2.3.2. Os grupo de professores. 11

2.3.2.1. Composição do grupo de professores. 
2.3.2.2. 0 resultado da aplicação do questionário aos professores.........12

2.3.2.3. A análise preliminar das respostas ao questionário aplicado aos professores.

2.3.3. Uma interpretação alternativa da origem dos problemas na relação Ensino/Aprendizagem .14

3. A PROPOSTA DE COMUNICAÇÃO COM O ALUNO 16

3.1.INTRODUÇ̃̃O.

3.2. OBJETIVOS PRELIMINARES DO CURSO PROPOSTO AOS

ALUNOS.

\subsection{A METODOLOGIA APLICADA}

3.3.1. A estratégia adotada.

3.3.2. Concepção e organização da pesquisa

3.3.2.1. A fase de "diagnóstico"

3.3.2.2. O plano de ação

3.3.2.2.1. A organização dos grupos

3.3.2.2. Os princípios gerais de funcionamento dos trabalhos

3.3.2.2.3. $O$ contrato pedagógico 21

3.3.2.2.4. Os perfis dos componentes de grupos. .21

3.3.2.2.5. $O$ estímulo 22

3.3.2.2.6. O registro de dados e documentação 22

3.3.2.7. Recursos didáticos. 23

4. REFERENCIAL TEÓRICO 24

4.1. INTRODUÇÃO 25

4.1.1. A escolha do modelo de análise psicanalítica .25

4.1.2. A escolha do modelo de análise pedagógica 26 
4.2. OS FUNDAMENTOS DO MODELO DE ENRIQUE PICHON-RIVIÈRE ....26

4.2.1. A nocão de vínculo.

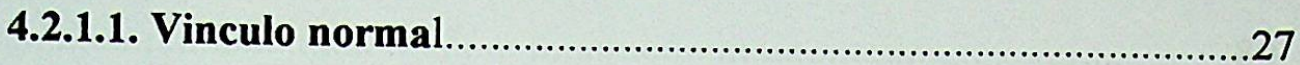

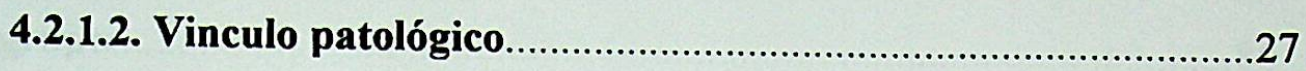

4.2.1.3. O vínculo, a comunicação e a aprendizagem........................28

4.2.1.4. Vínculo e a teoria dos três $\mathrm{D}$ (depositante, depositário e

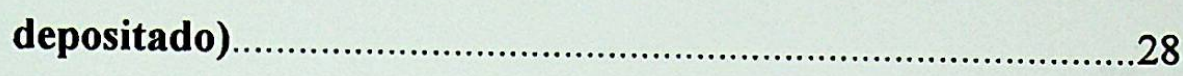

4.2.1.5. O conceito de papel...................................................................29

4.2.1.6. O conceito de "status".................................................................. 31

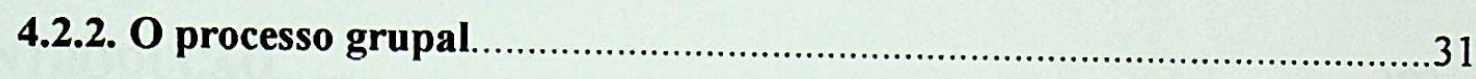

4.2.2.1. A pré-tarefa

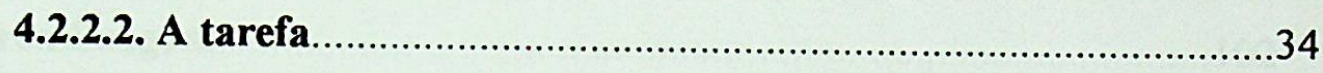

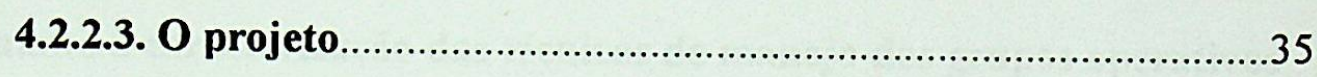

4.2.3. O esquema conceitual referencial operativo (E.C.R.O.)........................35

4.2.4. A relação entre grupos operativos terapêuticos e grupos operativos de

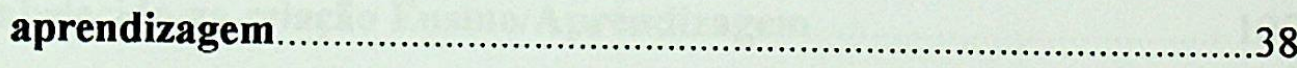

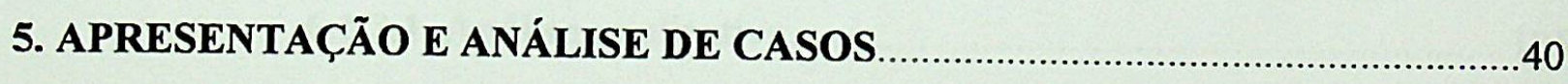

5.1. INTRODUÇÃO

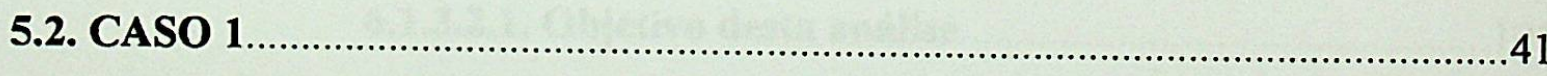

5.2.1. O grupo

5.2.2. O desenvolvimento do processo grupal .................................................42

5.3. CASO 2

5.3.1. O grupo

5.3.2. O desenvolvimento do processo grupal.................................................54

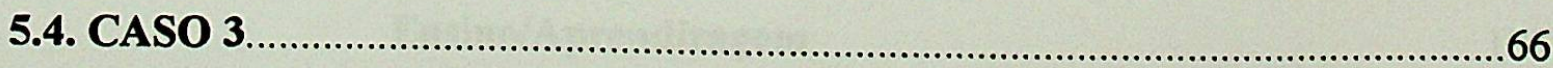


5.4.1. O grupo.

5.4.2. O desenvolvimento do processo grupal.

5.5. CASO 4

5.5.1. $O$ grupo

5.5.2. O desenvolvimento do processo grupal. .80

5.6. CASO 5 .88

5.6.1. O grupo 88

5.6.2. O desenvolvimento do processo grupal .88

6. CONCLUSÕES 101

\subsection{INTRODUÇÃO}

6.1.1. Quanto ao desenvolvimento próprio dos grupos operativos de aprendizagem

6.1.2. Quanto à caracterização das técnicas de manejo dos grupos operativos de aprendizagem.

6.1.3. Quanto à possibilidade concreta da reversão do processo de conflito estabelecido na relação Ensino/Aprendizagem.

6.1.3.1. Análise qualitativa.

6.1.3.2. Análise quantitativa 105

6.1.3.2.1. Objetivo desta análise.

6.1.3.2.2. $O$ resultado da aplicação do questionário aos alunos

6.1.3.2.3. A análise preliminar das respostas ao questionário aplicado aos alunos.

6.1.3.3. Conclusão quanto à possibilidade concreta da reversão do processo de conflito estabelecido na relação

Ensino/Aprendizagem 
6.1.4. Quanto aos fatores que podem influenciar positivamente a "mudança de olhar" entre Aluno, e Escola/Professor.

BIBLIOGRAFIA

ANEXOS.

ANEXO 1: O TESTE SOCIOMÉTRICO APLICADO AOS ALUNOS

ANEXO 2: O TESTE DE AVALIAÇÃO DOS CONCEITOS PRIMITIVOS. 116

ANEXO 3: O QUESTIONÁRIO APLICADO AOS ALUNOS 118

ANEXO 4: O QUESTIONÁRIO APLICADO AOS PROFESSORES. 120

ANEXO 5: OS FUNDAMENTOS CONSIDERADOS PARA NOSSA ESCOLHA DA PESQUISA-AÇÃO.

ANEXO 6: O CONTRATO PEDAGÓGICO; CONDIÇÕES PARA O TRABALHO EM GRUPO. O QUE NÃO DEVE ACONTECER! 124

ANEXO 7: OS PERFIS DE ATITUDES DOS COMPONENTES DOS GRUPOS. 


\section{LISTA DE IUUSTRAÇÕES}

Figura 1 - Cone invertido - uma visão da dinâmica do ECRO. 


\section{RESUMO}

O presente trabalho, que relata o desenvolvimento grupal de 5 casos representativos, de uma amostragem total de 28 casos estudados, pretende mostrar o processo de mobilização destes grupos operativos de aprendizagem, e, analisar e compreender, a partir do referencial teórico desenvolvido por Enrique Pichon-Rivière, as eventuais correlações entre as mudanças provocadas na relação ensino aprendizagem estimuladas pela aplicação das técnicas de trabalho em grupos operativos, em cursos experimentais de Física destinados a alunos do Ensino Médio.

Palavras-chave: Grupos operativos de aprendizagem; Cursos experimentais de Física; Ensino de Física. 
ABSTRACT

This essay that reports 5 representative events from an universe of 28 researched events, intends to analyze and to comprehend, starting from the theoretical references developed by Enrique Pichon-Rivière, the possible correlation among the changes in the teaching learning relations estimulated by working technicians application in learning operatives groups, in experimental courses of Physics for Ensino Médio (equivalent to High School) Brazilian students.

Key words: Learning operatives groups; Experimental courses of Physics; Physics Teaching. 


\section{RESUMEN}

Este trabajo, que relata el desarollo grupal de 5 casos representativos, de un universo total de 28 casos estudiados, intenta presentar el proceso de mobilizacion de estos grupos operativos de aprendizaje y, analizar y comprender, a partir de la propuesta teórica presentada por Enrique Pichon-Rivière, las eventuales correlaciones entre los cambios provocados por la aplicacion da las técnicas de trabajo em grupos operativos, en la relacion ensenãnza aprendizaje, en cursos experimentales de ensenãnza de Física para alumnos del curso de Bachillerato (que és el curso que se equivale al "Ensino Médio" en Brazil).

Palabras-llave: Grupos operativos de aprendizaje; Cursos experimentales de Física; Ensenãnza de Física. 
1. INTRODUÇÃO: UMA APROXIMAÇÃO AOS PROBLEMAS NA RELAÇÃO ENSINO APRENDIZAGEM 


\section{INTRODUÇÃO}

Durante os mais de 25 (vinte e cinco) anos em que atuo como professor e, mais acentuadamente, nestes últimos $10(\mathrm{dez})$ anos, tenho observado uma crescente deterioração da relação Ensino/Aprendizagem, ou seja, um aumento do número, da freqüência, da diversidade de causas de conflito, e da intensidade dos conflitos entre os componentes primários da relação pedagógica Alunos $\leftrightarrow$ Aprendizagem $\leftrightarrow$ Escola/Professor.

Devo ressaltar que, em minha opinião, essa referida deterioração não se limita, simplesmente, a uma questão de redução de conteúdo aprendido, ou a uma redução do nível de profundidade desse suposto aprendizado, ou ainda ao baixo índice de resultados alcançados - visto que a eficiência nessas questões pode ser facilmente manipulada, em função desse ou daquele interesse. Me parece que estamos frente a frente com um fenômeno mais basilar.

De início, minhas tentativas de reverter esse processo consistiram da aplicação de diversas metodologias ou tecnologias educacionais, consideradas, cada uma em seu momento, como uma espécie de "solução definitiva". Utilizei recursos visuais, dinâmicas convencionais de grupo, aulas com experimentos, enfim, tudo que pudesse trazer algo de novo, de positivo, para aquela relação, já desgastada. No entanto, as mudanças observadas nunca se mostraram significativamente satisfatórias.

Felizmente, em 1.998, tive a oportunidade de introduzir numa escola em que lecionava, e que no presente trabalho identifico como Escola 2, um laboratório de Física, aberto para a "criatividade". Esse laboratório, fundamentalmente, consistiu de um espaço, para aulas opcionais, fora do horário regular, em que os alunos trabalhavam em grupos, com liberdade de participação, de escolha de tema de pesquisa, e independente de notas ou quaisquer outros benefícios diretos.

Logo os primeiros resultados se mostraram agradavelmente surpreendentes. Foi fascinante descobrir que o mesmo aluno que durante as aulas convencionais assumia um determinado papel - distante, desinteressado, passivo - no período do laboratório assumia outro papel, nitidamente mais positivo; e que, logo em seguida, essa mudança também se refletia nas aulas convencionais.

Para mim, hoje, está claro que naquele momento eu não entendia efetivamente o processo que estava observando. Naquele momento eu associava essa mudança de atitude 
dos alunos à "liberdade" de opção, recém adquirida, ou ao alívio devido à redução da pressão exercida pelo fator nota, ou ainda simplesmente à possibilidade de "criar".

Minha visão inicial, bastante simplista, era, portanto, a de que se agrupamentos de alunos "decidissem" por eles próprios quando trabalhar, como trabalhar, e sobre o que trabalhar, teríamos a possibilidade concreta de que mudassem de atitude diante da relação Ensino/Aprendizagem.

No entanto, a observação continuada desse processo acabou por me mostrar que o nivel de produtividade alcançado pelos agrupamentos de alunos estava longe de ser o mesmo para todos os agrupamentos, como seria mesmo de se esperar, porém o surpreendente foi perceber que essa produtividade não dependia, essencialmente, do "potencial", no sentido mais conservador, dos componentes do grupo. Depois de observar a evolução de vários agrupamentos comecei a me convencer que, na verdade, essa produtividade dependia fundamentalmente do padrão de relações entre os elementos do próprio agrupamento, e entre esses elementos e o professor. O desenvolver do processo me fez sentir que quanto menos "rançosas" eram essas relações, mais ampla, e positiva, era a mudança de atitude dos alunos.

Eu precisava entender o que estava acontecendo. A partir de então, procurei adquirir formação sobre o tema. Tive, por exemplo, a oportunidade de participar dos encontros do Grupo de Pesquisa, orientado pelo Prof. Dr. Alberto Villani; participei, também, do curso "Noções Básicas de Grupalidade" oferecido pelo Núcleo de Estudos em Saúde Mental e Psicanálise das Configurações Vinculares - NESME; e, é claro, estudei uma vasta bibliografia sobre 0 assunto, de onde podemos destacar autores que consideramos de importância fundamental para este trabalho, como Enrique PichonRivière, e José Bleger.

$\mathrm{O}$ acesso a esse conhecimento me levou a desenvolver o presente trabalho de pesquisa, que tem como objetivo contribuir na compreensão da dinâmica dos problemas da relação Ensino/Aprendizagem, e que constitui, provavelmente, muito mais uma tentativa em que, como pesquisador, tento entender, e resolver meus próprios problemas e ansiedades, com os quais venho me deparando nestes últimos anos de trabalho como professor, do que propriamente numa proposta "definitiva" de alcançar esses objetivos de forma generalizada. 
2. O UNIVERSO DA PESQUISA 


\subsection{O PERFIL DAS ESCOLAS}

Acredito que o foco de nossas atenções deva sempre estar voltado para as tentativas de solução dos problemas mais gerais ou mais freqüentes. Por isso decidi realizar meu experimento em duas escolas de perfil significativamente representativo, dentro de nossa sociedade: uma escola pública estadual, localizada num bairro de periferia da cidade de São Paulo (chamarei de Escola 1), e a outra, uma escola particular, de classe média, instalada em bairro eminentemente de classe média, também da cidade de São Paulo ( que chamarei de Escola 2).

Na Escola 2, meu trabalho foi aplicado por 3 anos, na forma de um curso de laboratório de Física, dirigido à "criatividade", com o que quero dizer que a proposta do curso era a de que os alunos desenvolvessem um trabalho de pesquisa, sem compromisso com conteúdo curricular formal, e no qual tinham a liberdade de escolha de seu grupo de trabalho, forma de participação, de tema de pesquisa. Durante o primeiro ano de aplicação, tratou-se de uma atividade optativa que a escola colocou à disposição dos alunos, fora do horário normal de aulas, independente de notas ou quaisquer outros benefícios diretos. Nos anos seguintes, devido ao retorno apresentado pelos alunos, essa atividade passou a fazer parte da programação curricular da escola.

$\mathrm{Na}$ Escola 1, o trabalho começou um ano e meio após o início da pesquisa na Escola 2. Desse modo, foi possível resolver ou evitar, ao menos parcialmente, alguns dos problemas encontrados inicialmente quando da aplicação do curso na Escola 2. O formato do trabalho aplicado na Escola 1 foi o de um curso para alunos voluntários, com duração prevista de 2 meses (nesta atividade estivemos em parceria com Marcelo Alves Barros, atualmente Doutor em Educação pela Faculdade de Educação da USP).

\subsection{O PERFIL DOS ALUNOS}

O universo de pesquisa foi formado por alunos de $1^{\mathrm{a}}$ e $2^{\mathrm{a}}$ série do Ensino Médio.

Em ambos os casos (Escola 1 e Escola 2), cada uma das amostragem, se apresentou com um perfil social bastante homogêneo, mas significativamente diferentes entre si.

\subsubsection{Os alunos da Escola 1}

A pedido dos pesquisadores, esses alunos foram convidados pela direção da Escola 1 para a participação em um curso experimental, de aprendizado de ciências, com duração 
prevista de dois meses. Esse convite foi extensivo a todos os alunos das $1^{\mathrm{a}}$ e $2^{\mathrm{a}}$ séries do ensino médio, do período noturno, da escola em questão. Todos os alunos foram informados explicitamente de que os participantes não teriam nenhum tipo de premiação em termos de notas, e de que os assuntos abordados no curso não estariam diretamente ligados ao conteúdo curricular formal. Eles foram esclarecidos de que a participação no curso seria voluntária e de que os beneficios, se houvessem, seriam de aprendizado geral.

De um total de 200 alunos matriculados na escola, nas condições descritas acima, 40 alunos inscreveram-se no curso e, destes, 20 alunos se apresentaram à $1^{a}$ sessão (considero interessante citar, que durante a realização da pesquisa houve a inclusão voluntária de mais alguns alunos).

Devido à relativamente baixa relação número de alunos / número de pesquisadores do curso - 20 (vinte) alunos para 2 (dois) pesquisadores - foi possível realizar um trabalho de reconhecimento do quadro social formado por esses alunos bastante detalhado.

\subsubsection{A fase de "diagnóstico" aplicada aos alunos da Escola 1}

Nesta fase tentamos tomar conhecimento do "ecossistema" social com o qual estávamos nos propondo a interagir. Para tanto realizamos uma sessão, em clima informal, em que:

- $\quad$ Fizemos a apresentação do(s) pesquisador(es);

- Solicitamos a apresentação dos alunos;

- Com o objetivo de descobrir possíveis apoios ou resistências, tentamos:

- Identificar, através de testes sociométricos (ver ANEXO 1), os indivíduos e/ou grupos previamente envolvidos, em termos sociais/culturais;

- Determinar se já haviam participado de experiências semelhantes. Se obtiveram êxito ou fracasso;

- Identificar as dificuldades que julgavam apresentar, e porque acreditavam apresentar essas dificuldades;

- Identificar se acreditavam que sua dificuldade estava em compreender 0 conhecimento ou em comunicar sua proposta;

- Apresentar os objetivos do curso, no enfoque dos pesquisadores;

Por fim solicitamos... 
- Quais deveriam ser os objetivos do curso, no enfoque dos alunos;

e

- Aplicamos um pré-teste, com o objetivo de determinar os conceitos espontâneos dos alunos, relativos aos temas-conteúdo que seriam abordados na pesquisa (conforme ANEXO 2).

A análise das informações obtidas nessa primeira sessão revelou que aqueles alunos constituiam um conjunto muito homogêneo, de um padrão sócio-econômico baixo, com idade média de 18 (dezoito) anos - de modo geral trabalhavam durante algum período do dia - distantes dos meios de aquisição de formação e informação, tanto cultural-formal, quanto científica.

Esse conjunto de alunos, na quase totalidade, já participara de atividades de aprendizado em grupo, no entanto não consideravam que tivessem sido proveitosas. A aplicação dos testes sociométricos (ANEXO 1) não mostrou lideranças ou grupos espontâneos bem definidos, possivelmente porque os alunos que se apresentaram como voluntários pertenciam às diferentes classes da escola; ainda assim, os de uma mesma classe não demonstraram ligações consideráveis. Quando questionados sobre o porque participavam do curso, todos os alunos concordaram com que o aprendizado poderia representar um caminho de melhora social.

Durante esse primeiro contato, os alunos se mostraram, no geral, pouco comunicativos (alguns deles, mesmo quando estimulados, chegaram a se negar a fazer qualquer comentário). Quando fizeram algum comentário, apresentaram dificuldade de comunicação verbal: idéias pouco organizadas, fala truncada, caracterizada pelo emprego de vocabulário pobre, emissão de frases curtas, e uso freqüente de gírias.

A análise do teste de avaliação escrito (ANEXO 2), aplicado nessa sessão, indicou que apresentavam desarticulação entre conceitos espontâneos, dificuldade de estruturação e de associação entre eventos e idéias, além de confirmar as deficiências de comunicação.

\subsubsection{Os alunos da Escola 2}

No caso da Escola 2, o processo de abordagem dos alunos foi significativamente diferente. Como já disse anteriormente, logo no início do periodo de observação desta pesquisa, ( $2^{\circ}$ semestre de 1998), a direção da Escola 2, disponibilizou como atividade 
optativa, para os alunos de $1^{\mathrm{a}}$ e $2^{\mathrm{a}}$ série do Ensino Médio, do período matutino, um curso de laboratório de Física, dirigido à "criatividade", com a proposta de estender-se ao longo do ano letivo. Esse curso foi realizado em horário fora do período escolar. Também, aqui, a direção da escola deixou bem claro a todos os alunos que os participantes não teriam nenhum tipo de premiação em termos de notas, bem como os assuntos abordados no curso não estariam diretamente ligados ao conteúdo curricular formal, e de que, portanto, os benefícios seriam de aprendizado geral.

A adesão dos alunos foi massiva. Tivemos mais de 80 (oitenta) alunos participantes (40 alunos de cada série). Esse elevado índice de alunos, neste caso, para um único pesquisador certamente deve ter impedido, no início, e dificultado bastante, ainda no final do experimento, o levantamento formal e registro de muitas e valiosas informações durante a evolução do experimento.

\subsubsection{A fase de "diagnóstico" aplicada aos alunos da Escola 2}

Apesar dessas dificuldades, após o primeiro encontro, ficou perfeitamente claro que esses alunos constituíam, também, um conjunto muito homogêneo, de padrão sócioeconômico caracteristicamente de classe média, com idade média 16 (dezesseis) anos, com acesso relativamente fácil à formação e informação, tanto no aspecto cultural-formal quanto científica. Da mesma forma que os alunos da Escola 1, esse conjunto de alunos, na quase totalidade, já participara de atividades de aprendizado em grupo, no entanto não consideravam que tivessem sido proveitosas. A aplicação de testes sociométricos (ANEXO 1) não identificou lideranças significativas, no entanto mostrou uma forte tendência à formação de grupos espontâneos bem definidos. Aqui, somente quando estimulados, os alunos concordaram em que o aprendizado poderia representar para eles um caminho de evolução social.

Estes alunos, embora mais comunicativos, também apresentaram dificuldade de comunicação verbal: idéias pouco organizadas, fala truncada, caracterizada pelo emprego de vocabulário pobre, emissão de frases curtas, e uso freqüente de gírias.

$\mathrm{Na}$ Escola 2 o pré-teste para avaliação dos conceitos espontâneos, foi sempre informal, consistindo de uma rápida conversa com o objetivo de levantar os conceitos preestabelecidos relativos ao conteúdo a ser abordado pelos grupos individualmente. Durante essa avaliação os grupos demonstraram desarticulação entre conceitos 
espontâneos, alguma dificuldade de estruturação e de associação entre eventos e idéias, além de confirmar as deficiências de comunicação.

\subsection{UMA TENTATIVA DE IDENTIFICAR A ORIGEM DOS} PROBLEMAS NA RELAÇÃO PEDAGÓGICA ENSINO/APRENDIZAGEM

Muito embora, no atual momento histórico social, a existência de uma enorme incidência e diversidade de dificuldades na relação Ensino/Aprendizagem esteja mais que evidente, e que até em alguns casos nossos sentidos nos indiquem quais são essas dificuldades e eventualmente o porque delas, por considerarmos que o conhecimento do explícito dessa relação, no âmbito social ou institucional, seja absolutamente necessário e até determinante para a compreensão dessa problemática, nos propusemos a realizar o levantamento específico dessas informações tanto do ponto de vista do aluno quanto no enfoque do professor, visto que constituem elementos ativos da situação triangular básica (Aluno, Aprendizagem, Escola/Professor).

Como estratégia para identificar as dificuldades da relação Ensino/Aprendizagem consideramos dois grupos amostrais - um, de alunos, e o outro de professores (vértices distintos daquela relação triangular básica) - aos quais solicitamos que respondessem, cada qual, a um questionário específico (ver ANEXOS 3 E 4).

\subsection{1. $\mathrm{O}$ grupo de alunos}

\subsubsection{Composição do grupo de alunos}

Foi constituído por 100 (cem) alunos do Ensino Médio, voluntários, de diversas escolas, públicas ou particulares, da mesma região, e consequentemente com o mesmo perfil estatístico dos alunos da Escola 1 e Escola 2 (desta pesquisa não participaram alunos da Escola 1 ou Escola 2).

Esses alunos, portanto, não participaram de nosso experimento principal, nem tiveram nenhum tipo de contato com o pesquisador. Foram informados de que não havia a necessidade de identificar-se, e de que sua participação, ou não, da pesquisa não se lhes traria nenhum benefício ou prejuizo imediato. Nada lhes foi dito com relação ao objetivo da pesquisa, além de que respondessem às questões propostas apenas com a verdade. A pesquisa foi aplicada por terceiros, professores, na ausência do professor-pesquisador.

\subsubsection{O resultado da aplicação do questionário aos alunos}


As respostas dadas pelos alunos às questões apresentadas foram tabuladas e 0 resultado está apresentado abaixo.

1) Você gosta de sua escola?

$55 \mathrm{Sim}$.

36 Médio.

09 Não.

2) Você tem muitos(as) amigos(as) na sua escola?

$42 \mathrm{Sim}$.

54 Médio.

04 Não.

3) Você gosta de estudar?

$08 \mathrm{Sim}$.

20 Médio.

72 Não.

4) Você acha que a escola é importante para que a pessoa vença na vida?

$12 \mathrm{Sim}$.

34 Médio.

54 Não.

5) Você acha que a escola pode ajudar a que as coisas melhorem em seu país?

$14 \mathrm{Sim}$.

29 Médio.

57 Não.

6) E você... Você acha que pode ajudar a que as coisas melhorem em seu país?

09 Sim.

23 Médio.

68 Não.

7) Você acha que a maioria de seus professores é competente?

$14 \mathrm{Sim}$.

38 Médio.

48 Não.

8) Você acha que a maioria de seus professores se preocupa com você?

$13 \mathrm{Sim}$.

36 Médio.

51 Não.

9) Você acha que a maioria de seus professores trabalha para que as coisas melhorem em seu pais?

$16 \mathrm{Sim}$.

37 Médio.

47 Não.

10) Aponte as 3 (três) piores coisas de uma aula.

Aqui, tomamos a liberdade de relacionar as 5 (cinco) principais queixas (em ordem decrescente de freqüência), além de editar os textos próprios dos alunos.

a) Aulas em que os assuntos abordados não têm ligação com a realidade do aluno;

b) Aulas muito paradas; 
c) Aulas muito teóricas;

d) Não compreender os enunciados;

e) Ter que "decorar muitas fórmulas".

\subsubsection{A análise preliminar das respostas ao questionário aplicado aos alunos}

Acreditamos que a análise dessas respostas apresentadas pelos alunos nos permite uma visão, inserida num contexto grupal e institucional, suficientemente clara sobre a imagem que $o$ aluno internaliza de sua relação com os objetos Escola/Professor e Aprendizagem.

Se observarmos as respostas dadas às questões 1), 2), 3), 4), 5) e 8), parece-nos bastante claro, que no presente momento, a escola representa para o aluno tão somente uma oportunidade para o encontro social com a qual ele, sujeito, não estabelece e não pretende estabelecer qualquer outro tipo de relação ou compromisso.

Alem disso, as respostas dadas às questões 7), 8), 9) e 10) caracterizam bastante claramente qual a imagem que o aluno internaliza do professor - imagem essa que identifica no professor um indivíduo sem competência, desinteressado tanto por ele, como objeto Aluno, quanto pela situação social em geral, anacrônico, e com o qual a comunicação é difícil.

Em continuação, as respostas dadas às questões 4), 5) e 6) parecem mostrar uma descrença tanto em seu potencial como sujeito, aspecto indicativo de baixa autoestima, quanto na sociedade ao seu redor, o que implica no estabelecimento de vínculos negativos com a sociedade em geral, e conseqüente desrespeito às regras sociais.

Então, se considerarmos essas imagens internas estabelecidas no Aluno, como sujeito, em que a escola, o professor, a sociedade, apresentam funções alteradas, com as quais esse sujeito não tem qualquer identificação, não estabelece vínculos positivos, nem canais de comunicação e sem perspectivas de mudanças, é perfeitamente possível compreender, nos alunos, o porque dos conflitos na relação Ensino/Aprendizagem.

\subsection{2. $\mathrm{O}$ grupo de professores}

\subsubsection{Composição do grupo de professores}

Foi constituído por 20 (vinte) professores do Ensino Médio, de diversas escolas, públicas ou particulares, da mesma região da Escola 1 e Escola 2, de diversas disciplinas 
(humanas, biológicas e exatas), voluntários, e que necessariamente, além de não pertencer ao círculo de relacionamentos do pesquisador, não conheciam o objetivo da pesquisa. Foram informados de que não era necessária sua identificação, e de que sua participação ou não da pesquisa não se lhes traria nenhum benefício ou prejuizo imediato.

\subsubsection{O resultado da aplicação do questionário aplicado aos professores}

As respostas dadas pelos professores às questões apresentadas foram tabuladas e o resultado está apresentado abaixo.

1) Você gosta da(s) escola(s) em que trabalha?

$02 \mathrm{Sim}$.

12 Médio.

06 Não.

2) Você gosta de lecionar?

04 Sim.

14 Médio.

02 Não.

3) Você acha que a escola é importante para que o aluno vença na vida?

$02 \mathrm{Sim}$.

17 Médio.

01 Não.

4) Você acha que a escola atual pode ajudar a que as coisas melhorem em seu país?

02 Sim.

09 Médio.

09 Não.

5) Você acha que a maioria de seus alunos esta interessada em aprender?

$01 \mathrm{Sim}$.

07 Médio.

12 Não.

6) Você acha que a maioria de seus alunos espera trabalhar para que as coisas melhorem em seu país?

$01 \mathrm{Sim}$.

06 Médio.

13 Não.

7) E você... Você acha que pode ajudar a que as coisas melhorem em seu país?

$02 \mathrm{Sim}$.

07 Médio.

11 Não.

8) Aponte as 3 (três) piores coisas do Ensino/Aprendizagem atual.

Aqui, novamente, tomamos a liberdade de relacionar as 5 (cinco) principais queixas (em ordem decrescente de freqüência), além de editar os textos próprios dos professores.

a) As diretrizes oficiais atuais não incentivam a aprendizagem;

b) Alunos sem motivação e sem base;

c) Falta de tempo para preparação de aulas e/ou atividades; 
d) Falta de tempo para re-capacitação;

e) Falta de incentivo para re-capacitação.

\subsubsection{A análise preliminar das respostas ao questionário aplicado aos} professores

Também, neste caso, acreditamos que, sempre dentro do contexto grupal e institucional, os resultados obtidos permitem uma visão bastante clara, da imagem que $o$ professor internaliza de sua relação com os objetos Aluno, Escola e Aprendizagem.

As respostas dadas pelos professores às questões 3 ), 4), e 8), sugerem de forma bastante clara que, no presente momento, a imagem que 0 professor internaliza da instituição Escola, ou seja, da postura social e orientação gerencial da Escola, ou ainda do Estado como elemento social mantenedor da Escola, está associada a uma estrutura viciada, desgastada, que não lhe permite condições para exercer sua função. Consequentemente o sujeito, Professor, estabelece com o objeto, a instituição Escola, um vínculo negativo, e isso fica explícito na respostas apresentadas às questões 1) e 2).

Temos também a questão da imagem que o Professor internaliza do Aluno. Se analisarmos as respostas dadas pelos professores às questões 5), 6), e 8) concluiremos que o Professor vê no Aluno um individuo profundamente desinteressado, e sem competência social, e com o qual, portanto, somente resta estabelecer um vinculo negativo ou de distanciamento.

Por outro lado, as respostas dadas às questões 2), 7) e 8) são indicadores de desinteresse ou apatia, ou até mesmo de insegurança quanto à sua capacitação para a realização de seu trabalho, gerando um forte sentimento de baixa autoestima.

Esse estado de coisas, gerador de conflitos internos, certamente desperta no Professor as ansiedades de perda e ataque que vão estabelecer uma dinâmica relacional estereotipada em que as imagens que o sujeito Professor internaliza da sociedade, da Escola, do Aluno, representam, mais uma vez, funções alteradas, com as quais esse sujeito não estabelece vínculos positivos, e nem visualiza perspectivas de mudanças.

Portanto, não nos parece tarefa difícil compreender, também, as razões dos professores nos conflitos na relação Ensino/Aprendizagem. 


\subsubsection{Uma interpretação alternativa da origem dos problemas na relação}

\section{Ensino/Aprendizagem}

A análise preliminar das informações obtidas nas respostas aos questionários, apresentadas por alunos e professores, corroborada por nossa experiência de mais de 25 anos como professor, e ainda outros 17 (dezessete) anos como aluno, nos leva a identificar como origem elementar dos problemas na relação Ensino/Aprendizagem, o franco recrudecimento da imagem estereotipada estabelecida pelos 3 (três) vértices da relação triangular Aluno, Professor/Escola, Aprendizagem.

Se considerarmos, paralelamente, o desenvolvimento do processo histórico-social recente, a evolução do processo de conflitos na relação Ensino/Aprendizagem, e o padrão de imagens estereotipadas estabelecidas, mutuamente, entre os sujeitos da relação triangular Aluno, Professor/Escola, Aprendizagem, que estabelecemos a partir da análise dos questionários, somos levados a concluir que esse fenômeno se deve ao fato de que tanto a instituição Professor/Escola, quanto a instituição Aluno, quanto a instituição Aprendizagem, tiveram, estimuladas pela polarização do desenvolvimento social (e aqui não iremos discutir as razões, as responsabilidades ou os interesses envolvidos nesse processo), durante estes últimos 30 (trinta) anos, uma evolução em que se adjudicou a essas instituições papéis nos quais suas funções foram sendo alteradas, dando origem a um mecanismo dinâmico de instabilidade generalizada, ou seja, de perda de referenciais estáveis. Essa instabilidade estimula os medos básicos de perda e de ataque, o que certamente constitui uma dificuldade à compreensão da realidade, com o conseqüente estabelecimento das ansiedades básicas, que por sua vez tendem em cada componente e para cada componente da relação ensino aprendizagem, estimular a formação de uma imagem cada vez mais estereotipada.

Dentro desse raciocínio, portanto, o processo de deterioração se deve ao estabelecimento de um jogo de representações e transferências, alteradas e negativas, entre as instituições Aluno, Escola/Professor e Aprendizagem, provocados pela obstrução dos canais de comunicação devido a ruídos cuja origem reside na orientação do desenvolvimento social vigente, e que se configura como a fonte geradora das ansiedades básicas nos componentes dessa relação. Ou seja, os canais de acesso da comunicação entre esses componentes foram sendo obstruídos por ruídos provocados pelo desenvolvimento social dominante. Esse estado de coisas deu origem a um mecanismo dinâmico de desestabilização que atua como espiral dialética invertida, isto é, à medida que aquele 
mecanismo dinâmico de instabilidade evolui, o movimento dialético constituído pelo questionamento e esclarecimento autointerativo entre os componentes do processo Ensino/Aprendizagem involui, levando toda comunicação ao implícito, e provocando, portanto, o eventual colapso da relação Ensino/Aprendizagem. 
3. A PROPOSTA DE COMUNICAÇÃO COM O ALUNO 


\subsection{INTRODUÇÃO}

A crescente aceleração do desenvolvimento, em todas as áreas do conhecimento humano, dificulta, e muito, a antecipação das dificuldades que nossos descendentes terão que enfrentar para dominar esse conhecimento, e conseqüentemente torna muito difícil, para nós professores, estabelecer quais os conteúdos programáticos que poderão atender, de forma eficiente, às exigências dessa escalada de conhecimentos.

Considero, por isso, que para qualquer que seja o modelo de Ensino/Aprendizagem que venha a emergir no futuro é fundamental que se priorize, não exatamente o conteúdo, mas, principalmente, o processo de aprendizado.

A partir dessa premissa, minha proposta principal nesta pesquisa, em termos de estratégia de comunicação com o aluno, foi sempre a de apresentar um curso voltado essencialmente para o estímulo e desenvolvimento da iniciativa, no aluno, como método para alcançar o aprender a aprender.

\subsection{OBJETIVOS PRELIMINARES DO CURSO PROPOSTO AOS}

\section{ALUNOS}

Para atender a essa demanda, à qual me refiro na introdução, cada vez mais acentuada, é absolutamente necessário que esse processo de aprendizado desenvolva no aluno:

- $\quad$ a capacidade de observação;

- $\quad$ o senso crítico;

- $\quad$ o trabalho de pesquisa;

- $\quad$ a capacidade de comunicação;

e que, além disso, promova ou estimule no aluno:

- a mudança conceitual em relação aos conceitos preestabelecidos;

- $\quad$ envolvimento no processo de aprendizado;

- a análise dos vínculos que se estabelecem entre os componentes de grupo e como isso interfere e influencia na mudança conceitual;

- observação e compreensão das mudanças de atitudes provocadas pelo 
trabalho em grupo, nele próprio, e também nos demais componentes, tanto no domínio do próprio grupo quanto em sua interação com os demais grupos.

\subsection{A METODOLOGIA APLICADA}

\subsubsection{A estratégia adotada}

Para mim, tanto no papel de pesquisador, como no de professor-coordenador de grupos, ficou mais do que claro desde os primeiros experimentos, que o resultado da pesquisa, e a evolução do trabalho nos grupos, dependeria da qualidade da observação dos processos que se estabeleceriam nas relações entre os componentes dos grupos, entre os grupos, e entre o(s) pesquisador(es) e os grupos. Além disso, desde o início, também havia grande interesse em compreender como o processo grupal interferiria na tomada de consciência e na mudança de atitude desses alunos em termos de mecanismos de aquisição de conhecimento.

Por outro lado, a pesquisa não poderia deixar de considerar que, em todas essas relações, todos os participantes teriam algo a fazer e dizer. Essas ações, índices das relações sociais estruturadas nos grupos, poderiam fornecer um perfil da situação dos grupos em tempo real. Isso, certamente deveria ser considerado, não apenas na observação dos processos, mas também, principalmente, na re-transformação dos objetivos dos grupos.

Acreditamos que o método de pesquisa-ação (compreendido conforme apresentado no ANEXO 5), é o que permite aos participantes a maior eficiência em termos de "feedback" nas situações que se apresentam, principalmente em termos re-polarização de ações de transformação.

Consideramos que os principais diferenciais dessa estratégia (a pesquisa-ação) em nosso contexto foram:

- viabilizar a obtenção de informações sobre a evolução interna, individual (no sujeito), e coletiva (no grupo), perante fatos e/ou problemas concretos, que não seriam detectadas pelos processos convencionais, tendo em vista que sem a participação ativa dos sujeitos da pesquisa, os pesquisadores apenas teriam acesso a "imagens" estáticas ou deformadas dessas informações;

Outro diferencial significativamente vinculado ao modelo de mudança conceitual consistia em... 
- não considerar os sujeitos da pesquisa como indivíduos desinteressados ou ignorantes. Dessa forma os preconceitos espontâneos foram levados em conta, pelos pesquisadores, e foi a partir dessa condição que 0 conhecimento científico foi desenvolvido, ocorrendo um processo de aprendizagem significativo entre sujeitos e pesquisadores, pelo aproveitamento da competência mútua.

\subsubsection{Concepção e organização da pesquisa}

Mesmo antes de iniciar a pesquisa, devido a minha experiência como professor, já fazia uma idéia prévia daquilo com que iria me deparar. Estava consciente de que, a cada instante, devido à dinâmica própria dos grupos estudados e da interação entre pesquisador(es) e situações especificas encontradas, nos depararíamos (pesquisador e alunos) com múltiplas alternativas, o que é, inclusive, inerente a uma pesquisa-ação.

Como professor-coordenador de grupos, estava convencido de que essa dinâmica solicitaria continuamente a proposta de questões significativas, em seguida, a observação (tomada de dados), depois, a reformulação ou modificação daquelas questões significativas, em seguida, novo processo de observação, realinhamento do plano de ação, eventuais mudanças de tema das questões significativas, novo processo de observação, enfim, uma dinâmica de pesquisa com alto potencial de variações continuadas. Por isso, nos pareceu, ao menos útil, estabelecer, preliminarmente, a linha mestra de nossa pesquisa.

\subsubsection{A fase de "diagnóstico"}

Nesta fase, já descrita no CAPíTULO 2, tentei tomar conhecimento do "ecossistema" social com o qual me propunha a interagir.

\subsubsection{O plano de ação}

Uma vez determinado o perfil dos elementos, sujeitos de nossa pesquisa, de sua estruturação elementar, ou seja, de como esses sujeitos se relacionam entre si, e qual sua relação com o conhecimento e aprendizado, informações essa obtidas na fase de diagnóstico, tratamos de implementar um plano de ação, considerando, fundamentalmente os seguintes pontos:

- atingir as metas propostas, ou seja, alcançar o aprendizado significativo do tema conteúdo;

garantir a continuidade da ação - tendo em vista as dificuldades sociais às quais são submetidos determinados alunos participantes de nossa pesquisa; 
- assegurar a participação dos alunos, e estabelecer esforços no sentido de garantir a inserção dos alunos participantes nos grupos de trabalho;

- incorporar suas contribuições - consideramos extremamente útil a análise das contribuições dos alunos participantes, tanto no aspecto do conhecimento de seus conceitos espontâneos, quanto no aspecto subjetivo, quando o aluno passa a se conscientizar de que suas contribuições são significativas.

Nesse contexto o plano de ação consistiu em formar grupos de trabalho dentro do esquema descrito a seguir:

\subsection{A organização dos grupos}

Cada grupo foi constituído por, no mínimo, 03 (três) e, no máximo, 04 (quatro) alunos.

Tendo em vista que a proposta da pesquisa estava fundamentada na análise do trabalho em grupo, e das relações e papéis que os componentes viriam a assumir durante o desenvolvimento do trabalho grupal, não foi admitida nenhuma outra alternativa de trabalho.

\subsubsection{Os princípios gerais de funcionamento dos trabalhos}

Com o propósito de organizar, ao menos preliminarmente, o trabalho nos grupos, adotei um conjunto de regras gerais de trabalho (conforme Baldino, 1989).

- "Os grupos serão formados a partir de uma avaliação prévia sobre concepções alternativas dos estudantes. Caso os alunos optem pela formação de grupos espontâneos, os pesquisadores se guardarão o direito de reformular os grupos, se forem detectados problemas no funcionamento individual ou geral dos grupos;

- $\quad$ Supremacia dos grupos sobre os individuos e do grupão sobre os grupos;

- Aumento da competência média da turma, não da competência máxima de alguns;

- Acompanhamento do raciocinio, não correção do resultado;

- Prêmios e sanções à turma e aos grupos, não aos individuos;

- Instalação de foro de debate sobre o papel da escola." (Baldino, 1989) 
Todos os alunos foram informados - de forma clara, adequada à sua compreensão, mas com o cuidado de não parecer uma imposição - quanto a esses princípios gerais, bem como lhes foi explicado a importância de obedecer a esses princípios, durante o funcionamento dos trabalhos.

Apenas como observação acredito que é relevante ressaltar que essa parametrização revelou-se muito positiva tanto para a estruturação e organização dos trabalhos, quanto como elemento de equalização de desenvolvimento dos componentes dos grupo. No entanto, por parte dos alunos, nunca foi atingida, efetivamente, a assimilação significativa desses princípios - a cada momento era necessário relembrar os princípios, que logo em seguida eram quebrados, fazendo-se necessário relembrá-los novamente, num processo que se estendeu por toda a pesquisa.

\subsubsection{3. $\mathrm{O}$ contrato pedagógico}

Após a formação dos grupos iniciais, com a finalidade de organizar os esforços e na tentativa de otimizar os trabalhos, foi sugerido e apresentado formalmente, de início, um "esquema de trabalho", que denominamos contrato pedagógico (conforme ANEXO 6).

É importante ressaltar que, já que pretendíamos estabelecer um regime de trabalhos totalmente aberto - nossa proposta era que a iniciativa de criação de critérios para o trabalho partisse deles, sujeitos, enquanto grupos - assim, para não estimular o estabelecimento de nenhum tipo de comportamento grupal previamente concebido, foi apresentado aos alunos, na verdade, o anti-regime de trabalho.

Compreendido desse modo, a "apresentação" do contrato pedagógico teve o propósito exclusivo de dificultar possíveis acomodações do(s) grupo(s).

\subsection{Os perfis dos componentes de grupos}

Além do esclarecimento relativo ao "contrato de trabalho" os alunos foram orientados - aqui também, de forma clara, adequada à sua compreensão, e com cuidado de não parecer uma simples rotulagem pejorativa - sobre as diversas tendências de atitudes que podem se manifestar nos indivíduos durante o desenvolvimento grupal. Esses perfis (ANEXO 7) foram apresentados para eles, alunos, com o objetivo de fornecer-lhes ferramentas que facilitassem continuamente tanto a auto análise quanto análise da atitude dos colegas, e, conseqüentemente a compreensão dos problemas ou situações grupais. 


\subsubsection{5. $\mathrm{O}$ estímulo}

Cada aula teve início com a sugestão ou realização de uma atividade, ou experimento, concreto ou hipotético, significativo - por exemplo, para a $1^{\text {a }}$ aula de trabalhos com as turmas de $2^{\mathrm{a}}$ séries estava previsto o clássico experimento da água "quente", "fria" e "morna" - com o propósito de expor conflitos, levantar questões e despertar o interesse e curiosidade pelo científico nos alunos. Em seguida, cada grupo de alunos da Escola 1, em função de seu tema específico, recebeu uma lista com questões conceituais que deviam ser resolvidas por eles. Estas questões foram propostas no sentido de: colocar o aluno diante de situações conflitantes de modo que viesse a questionar seus conceitos espontâneos, estabelecer um fio condutor para o aprendizado, criar condições para discussão em grupo, promover a tomada de funções do sujeito no grupo, estimular a pesquisa individual e em grupo, propor modificações em seus conceitos espontâneos até que finalmente, e idealmente, o grupo chegasse ao modelo científico aceito. Enquanto que na Escola 2, cada grupo de alunos, também em função de seu tema específico, recebeu uma lista de sugestões de possíveis passos a seguir a fim de estabelecer um fio condutor dos trabalhos do grupo, criar condições para discussão, promover a tomada de funções do sujeito no grupo, estimular a pesquisa individual e em grupo, propor modificações em seus conceitos espontâneos até que finalmente, e idealmente, o grupo chegasse à realização de sua tarefa.

\subsection{O registro de dados e documentação}

As observações efetuadas pelo(s) pesquisador(es), em tempo real, foram registradas ou documentadas regularmente, logo após cada sessão, juntamente com suas análises e comentários; na Escola 2, esse processo, apresentou sérias dificuldades devido ao alto número de grupos por pesquisador, além do curto intervalo de tempo entre uma aula e outra (a cada 100 minutos de aula ou observação dispúnhamos de apenas 5 minutos de intervalo para efetuar as correspondentes anotações. Depois das aulas essas anotações eram completadas e organizadas ).

$\mathrm{Na}$ Escola 1, um dos grupos de trabalho foi escolhido, arbitrariamente, e sua atividade foi gravada em vídeo, para posterior análise; além disso, ainda na Escola 1, após as aulas, houve assembléias em que compareceram os pesquisadores e um representante de cada grupo. Além das anotações usuais dos pesquisadores, essas assembléias foram gravadas em vídeo, para posterior análise. 
Houve entrevistas periódicas (a cada 4 aulas) com os professores do programa oficial, com o objetivo de avaliar as possiveis mudanças de atitude dos alunos nas atividades curriculares.

Houve, também, o preenchimento de uma ficha diária, pelos grupos. O objetivo dessa ficha era o de proporcionar aos grupos uma possibilidade de autoavaliação que lhes permitisse a conscientização em termos de organização, produtividade e evolução.

\subsection{Recursos didáticos}

Durante as sessões de trabalho, os alunos tiveram livre acesso a:

- Equipamentos de laboratório didático: desse modo os alunos puderam realizar eventuais experimentos que acreditavam ser importantes - isso além de dismistificar 0 ato experimental em ciência, possibilitava a concretização de idéias, auxiliava a que desenvolvessem a capacidade de observação e o espírito crítico.

- Biblioteca: tendo em vista a necessidade de pesquisa e a dificuldade que isso podia representar para a maioria dos componentes dos grupos, colocamos à disposição dos alunos um acervo bibliográfico, composto de livros didáticos e técnicos, jornais e revistas que pudessem fornecer e estabelecer relações com os temas-conteúdo. É importante chamar a atenção ao fato de que em diversos grupos e ocasiões os próprios componentes dos grupos trouxeram sua própria bibliografia. 
4. O REFERENCIAL TEÓRICO 


\subsection{INTRODUÇÃO}

Tendo em vista que nossa proposta de trabalho está claramente fundamentada na observação das relações que se estabelecem entre sujeitos e objetos de nossa pesquisa, é claro, dentro de um contexto fundamentalmente de aprendizado, torna-se necessário formalizar o referencial teórico, suportado de um lado em bases psicanalíticas, e de outro pedagógicas, bem estabelecidas, a partir do qual pretendemos desenvolver nossa análise.

\subsubsection{A escolha do modelo de análise psicanalítica}

Após a leitura de diversos trabalhos sobre esse tema, desenvolvidos por relevantes autores, nos decidimos pelo modelo sustentado por Enrique Pichon-Rivière.

A escolha desse autor, reconhecidamente um dos psicanalistas mais importantes surgidos a partir da década de 40 , e um dos principais responsáveis pelo desenvolvimento da teoria dos grupos operativos, se deve em muito, é claro, à importância e atualidade de seu trabalho, mas não apenas a isso....Nossa decisão quanto ao referencial teórico adotado, somente ocorreu efetivamente após a obtenção do conjunto de dados da pesquisa. Dessa forma, pudemos observar cuidadosamente, e de modo geral com repetições, muitos dos padrões que se estabeleceram nas relações entre os sujeitos de nossa pesquisa, e concluímos que esses padrões nos parecem absolutamente compativeis com o modelo de relações vinculares proposto por Pichon-Rivière. Consideramos também a aplicabilidade destas técnicas operativas na compreensão de outras situações práticas (diferentes da situação ordinária de tratamento da doença mental) tais como em indústrias, empresas, na formação de líderes, na criação publicitária, no trabalho institucional, no estudo de direção e interpretação teatral, em hospitais, e, inclusive, na realização de um curso experimental de formação de psicanalistas.

Muito embora Enrique Pichon-Rivière tenha desenvolvido as bases de seu modelo sobre relações vinculares por toda sua obra, a profundidade requerida por nossa necessidade atual nos parece estar suficientemente bem sustentada em dois trabalhos Teoria do Vínculo, editora Martins Fontes, São Paulo, 1998, e O Processo Grupal, editora Martins Fontes, São Paulo, 1998. Estes trabalhos não são exatamente de sua autoria: o primeiro, consiste de transcrições de aulas suas, apresentadas na sede da Associação Psicanalítica Argentina, em 1956, coletadas e elaboradas por Fernando Terregano; o segundo, é uma coletânea de trabalhos relacionados ao tema "processo grupal", de autoria de colegas e colaboradores, selecionados por Pichon-Rivière. 


\subsubsection{A escolha do modelo de análise pedagógica}

Quanto ao modelo pedagógico a ser aplicado neste trabalho, a escolha recaiu na obra, ou ao menos em parte da obra, de Jean Piaget. Esta minha escolha se deve, tanto à indubitável importância de seu trabalho para a psicologia do conhecimento, e para a psicologia do desenvolvimento, quanto a suas contribuições para a epistemologia. No entanto, no contexto do presente trabalho, acredito que sua importância maior esteja ligada, mais especificamente, ao estudo das funções cognitivas tais como memória, linguagem e percepção, além do estudo dos sistemas auto-organizados.

\subsection{OS FUNDAMENTOS DO MODELO DE ENRIQUE PICHON-} RIVIÈRE

Para Pichon-Rivière existem três dimensões de investigação psicológica/psicanalítica - a investigação do indivíduo, a investigação do grupo e a investigação da instituição ou sociedade. A partir dessa plataforma são possíveis três tipos de análise - a psicossocial (que parte do indivíduo que se expressa para fora, que se dirige para os diferentes objetos que o rodeiam); a socio-dinâmica (que analisa o grupo como estrutura, considerando as diferentes tensões entre todos os objetos que configuram a estrutura do grupo); e a institucional (que assume o grupo como objeto de pesquisa total, sua estrutura, origem, história, etc... e que situam o sujeito como componente de uma instituição).

A partir desses elementos é perfeitamente possível estudar com operacionalidade científica as relações interpessoais que se estabelecem no grupo - o fundamento do que Pichon-Rivière chamou de Psiquiatria do Vínculo - e que utiliza como matéria prima de pesquisa como os indivíduos se relacionam uns com os outros, estabelecendo a cada momento, em cada situação, uma estrutura particular que chamaremos de vínculo. Sua utilidade, em termos de psicologia social, está no fato de que esse conceito, que apresenta características sempre sociais, é um conceito instrumental e assume uma determinada estrutura que é manejável operacionalmente. Por isso, o conceito de vínculo está relacionado com a noção de papel, de "status" e de comunicação. 


\subsubsection{A noção de vínculo}

"O vínculo configura uma estrutura dinâmica em contínuo movimento, que funciona acionada ou movida por fatores instintivos, por motivações psicológicas." (Pichon-Rivière)

Parece-me que essa forma de apresentar a noção de vínculo vai além da noção de relações de objeto, comumente aplicada em psicanálise.

Com essa forma de conceituar vínculo, Pichon-Rivière quer afirmar que:

- Vínculo é a relação de objeto constituída por uma estrutura que funciona de uma determinada maneira;

- Vínculo inclui um padrão de conduta relativamente fixo com o objeto, e que tende a se repetir automaticamente tanto na relação interna quanto na relação externa com o objeto;

- A maneira habitual de comportamento do sujeito pode ser compreendida como uma relação de objeto interno, ou seja, com a forma com que o eu desse sujeito se relaciona com a imagem interna que o sujeito tem do objeto.

Então, se conhecermos o vínculo interno e a forma com que o eu se relaciona com o objeto interno, é possivel compreender o sujeito.

\subsubsection{Vinculo normal}

É aquele que se estabelece entre o sujeito e um objeto quando ambos têm a possibilidade de fazer uma escolha livre do objeto, como resultado de uma boa diferenciação entre ambos. Nesse caso o objeto "bom" permanece continuadamente sem provocar patologias.

\subsubsection{Vinculo patológico}

"Por trás de toda conduta "desviada" subjaz uma situação de conflito, sendo a enfermidade a expressão de uma tentativa falida de adaptação ao meio. Em sintese, a enfermidade é um processo compreensivel." (Pichon-Rivière)

A sintomatologia do paciente, ou seja, a patologia, é um mecanismo de expressão das defesas do paciente. Portanto, o estudo psicossocial, socio-dinâmico e institucional do grupo de um determinado sujeito pode fornecer uma visão completa da estrutura mental e dos motivos ou causas que exerceram pressão sobre o sujeito e provocaram a ruptura de 
um equilibrio que se mantivera, até aquele momento, estável.

\subsubsection{O vínculo, a comunicação e a aprendixagem}

De acordo com o modelo de relações vinculares de Pichon-Rivière: "Não existem relações impessoais, uma vez que o vínculo de dois se estabelece sempre em função de outros vínculos condicionados historicamente no sujeito e que, acumulados nele, constituem o que denominamos o inconsciente. $O$ inconsciente, portanto, é constituido por uma série de pautas de conduta acumuladas em relações com vínculos e papéis que o sujeito desempenha diante de determinados sujeitos. Então, quando deposita sobre outro sujeito, mediante o mecanismo de deslocamento ou projeção, um determinado objeto interno, estabelece com ele um vínculo fictício, como o é, por exemplo, o vínculo transferencial, no qual o analista chega a ter as características de uma figura anterior e é operante, justamente por isso, no tratamento: porque através da transferência é possivel reviver o vínculo primitivo que o paciente tem com os sujeitos primários, de sua primeira época de vida. Desse modo, é possivel retificar a natureza dessas imagens e fazer a aprendizagem da realidade, a aprendizagem em sentido geral."

Desse modo, na medida em que a confrontação entre o âmbito do inter-subjetivo e o âmbito do infra-subjetivo, seja dialética ou problemática, esta aprendizagem será facilitada ou obstaculizada, e portanto as relações intra-subjetivas, ou estruturas vinculares internalizadas, articuladas em um mundo interno, condicionarão as características da aprendizagem da realidade. Ou seja, a evolução na aprendizagem da realidade dependerá de que o processo de interação funcione como um circuito aberto - com uma trajetória em espiral - ou como um circuito fechado viciado pela estereotipia.

\subsubsection{Vínculo e a teoria dos três $\mathrm{D}$ (depositante, depositário e depositado)}

Para Pichon-Rivière, o fenômeno fundamental da análise é o estabelecimento da comunicação entre analisando e analista. Este momento somente pode acontecer se e quando o analista assume o papel que lhe é adjudicado pelo analisando. Ou seja, quando o analista não aceita o papel que lhe é dado pelo analisando (depositante), inevitavelmente, a comunicação entre ambos não vai ocorrer.

Toda a atividade mental do analisando está orientada no sentido de estabelecer um canal de comunicação, qualquer que seja esse canal. E para atingir esse objetivo o analisando precisa depositar parte dele (depositado) no outro (o analista).

O primeiro contato entre analisando e analista será interpretado pelo analisando 
como amostragem dos contatos posteriores. Em geral, a quebra do canal de comunicação é provocada pela ansiedade do analista, tendo em vista que, mesmo nos casos mais graves, o analisando sempre e permanentemente busca alternativas de comunicação.

Ao analista cabe perceber a existência dessa comunicação, interpretá-la e utilizá-la como guia de trabalho (essa guia de trabalho se define, basicamente, já na primeira comunicação).

Então, para que se possa estabelecer a comunicação, o analista deve assumir a postura de depositário desapreensivo, o que implica em aceitar em depósito, sem demonstrar ansiedade, qualquer coisa que o analisado queira projetar nele, seja boa ou ruim, materna ou paterna, feminina ou masculina.

É essencial compreender as mensagens enviadas pelo analisando através de suas estereotipias. Isso porque o analisando organiza um "padrão" de conduta que representa toda sua vida mental, e a partir daí, se o analista receber essa mensagem poderá compreendê-la e interpretá-la na situação transferencial. As estereotipias apresentadas pelo analisando têm, portanto, para o analista um significado total.

\subsubsection{5. $O$ conceito de papel}

$\mathrm{Na}$ vida social todas as relações interpessoais são determinadas por uma dinâmica entre papéis assumidos e adjudicados. E é exatamente essa dinâmica que caracteriza os vínculos que se estabelecem no grupo e que lhe conferem seu padrão característico de organização.

Em condições normais, cada um de nós, pode assumir diversos papéis diferentes, ao mesmo tempo, sem nenhum desvio de comportamento geral.

Para Pichon-Rivière: "A teoria dos papéis baseia-se na teoria das relações de objeto. As relações de objeto são estruturas nas quais estão incluidos um sujeito e um objeto estabelecendo uma relação particular entre eles. Denominamos vínculo a esse conjunto, a essa estrutura especial. $O$ conceito de vínculo é operacional, configura uma estrutura de relação interpessoal que inclui, como já dissemos, um sujeito, um objeto, a relação do sujeito ante o objeto e a relação do objeto ante o sujeito, cumprindo os dois uma determinada função. Por isso, à idéia de um papel individual temos que agregar o conceito de papel do vínculo configurando uma estrutura social mais integrada. Por exemplo, um grupo de expressão, como se diz em sociologia, é um grupo encarregado de mover uma determinada ideologia; agrupa individuos que estabelecem identificações 
mútuas entrecruzadas, constituindo um vínculo estreito em função de uma determinada ideologia. Esse vínculo é ideológico e condiciona neles a existência de uma estrutura como totalidade, que começa a funcionar como um grupo, com uma dada ideologia e uma operatividade determinada, estabelecendo vínculos com outros grupos sociais. Portanto podemos falar de vínculos individuais e de vínculos grupais. ...Esses grupos vinculados podem tender, também, a ter um determinado papel, isto é, determinados grupos têm vínculos e papéis particulares. O conceito de papel, que começamos a conhecer individualmente, pode ser estendido aos grupos. Entre a assunção de um determinado papel e a adjudicação de um papel a outra pessoa existe seinpre um interjogo dialético em forma permanente. E aqui nos encontramos com o conceito de espiral. Na medida em que um adjudica e o outro recebe, estabelece-se entre ambos uma relação que denominamos vínculo. Este tende a se desenvolver dialeticamente chegando a uma sintese dos dois papéis, que é o que dará as características do comportamento tanto do individuo quanto do grupo considerado."

Em seu modelo sobre o conceito de papel, Pichon-Rivière, faz referência ao trabalho de George Mead, sobre esse tema: "segundo esse autor na mente de cada um de nós não só assumimos o nosso papel, mas assumimos também os papéis dos outros. Temos, então, uma dupla representação do que está acontecendo: uma fora e outra dentro. Cada um de nós tem um mundo interno povoado de representações de objetos onde cada um está cumprindo seu papel, uma função determinada, e é precisamente isso que torna possivel a previsão da conduta dos outros. A característica fundamental da inteligência humana é a de poder prever uma determinada situação baseada em processos de identificação com os objetos e a de poder assumir internamente esses papéis, sem a necessidade de expressá-los externamente."

Se cada integrante do grupo exerce uma função e uma categoria determinadas, parece-nos fundamental que dentro de um processo grupal deva-se analisar quais os papéis que estão sendo representados por cada participante do grupo.

Para Pichon-Rivière os papéis de significado mais representativo em termos de funcionalidade e mobilização do grupo são: "Porta-voz de um grupo é o membro que em um momento denuncia o acontecer grupal, as fantasias que o movem, as ansiedades $e$ necessidades da totalidade do grupo. Mas o porta-voz não fala só por si, mas por todos; nele se conjugam o que chamamos de verticalidade e horizontalidade grupal, entendendose por verticalidade aquilo que se refere à história pessoal do sujeito, e por 
horizontalidade, o processo atual que acontecendo aqui e agora, na totalidade do grupo.... Seguindo o processo natural de assunção e adjudicação de papéis, um membro do grupo se faz depositário dos aspectos negativos ou atemorizantes do grupo ou da tarefa, num acordo tácito no qual tanto ele como os demais componentes do grupo estão comprometidos. Aparecem então os mecanismos de segregação, configurando-se outra das situações significativas: a do bode expiatório. Outro membro, o líder, por outro lado, sempre pelo mesmo processo, pode fazer-se depositário de aspectos positivos do grupo, obtendo uma liderança que estará centrada em uma ou várias categorias... No entanto, ambos os papéis, o de lider e o de bode expiatório, estão intimamente ligados, já que o papel de bode expiatório surge como representação da liderança, através de um processo de dissociação ou "splitting", necessário ao grupo em sua tarefa de discriminação. Acrescentamos a esses três papéis o de sabotador, que é habitualmente, a liderança da resistência à mudança."

A partir do reconhecimento destes papéis, e de sua dinâmica, o analista poderá por meio de interpretações esclarecer ao analisando os conteúdos latentes de seus vínculos, para que finalmente, o analisando possa descobrir quem são na realidade o analista e ele.

À medida que o analisando vai se aproximando da normalidade começa a desempenhar, em cada momento e situação particular, um único papel.

\subsubsection{O conceito de "status"}

Os conceitos de papel e de "status" estão intimamente relacionados. Se considerarmos que cada elemento do grupo atua numa determinada função, de determinadas características e num determinado nível, o papel estará ligado à função e características do indivíduo no grupo; enquanto o "status" está relacionado com o nível de ação, com o prestígio.

\subsubsection{O processo grupal}

Para Pichon-Rivière, os grupos operativos se caracterizam pelo fato de que sua atividade central (a tarefa) consiste na mobilização de suas estruturas estereotipadas, ou na superação de dificuldades de aprendizagem e comunicação, situações estas geradas pelas ansiedades provocadas pelos medos de mudanças.

A partir da observação de repetições sistemáticas de determinados comportamentos grupais, Pichon-Rivière propôs uma escala de avaliação básica dessa dinâmica relacional. Num primeiro momento, o sujeito, ainda sem incluir-se totalmente no grupo, através de 
uma aproximação ou contato, pode tentar estabelecer um vínculo com o grupo - trata-se da afiliação ou identificação com os processos grupais. No momento seguinte, o sujeito se integra mais intensamente ao grupo. Isso traz maior segurança ao grupo, o que permite que o grupo passe a planificar - atingiu-se a pertença. Em seguida o sujeito passa a contribuir com o grupo, mesmo que discretamente - é o momento da cooperação. Essa contribuição acaba por estabelecer uma dinâmica de papéis que identifica, por um lado a operatividade do grupo, e por outro o conflito entre a verticalidade do sujeito e a horizontalidade do grupo. A seguir o grupo pode começar a elaborar e tentar concluir a tarefa proposta - 0 grupo atingiu a pertinência. Há ainda que se considerar a comunicação entre os componentes do grupo. Na comunicação, que pode ser verbal, pré-verbal ou gestual, devem ser considerados não apenas o conteúdo, mas o meio de comunicação, o emissor, os receptores e ruídos. Depois, temos a aprendizagem, caracterizada por uma mudança qualitativa do grupo, notável pela resolução das ansiedades, tomada de posição ativa em relação à realidade, e principalmente pela proposta de projetos. Tem-se também a telê, que se caracteriza por uma disposição ou ambiente grupal, resultado de uma transferência positiva ou negativa, de trabalhar com um específico membro do grupo, ou com o coordenador.

\subsubsection{A pré-tarefa}

Nesse momento, o grupo resiste às mudanças através da aplicação de técnicas diversivas, mobilizadas pelas ansiedades de perda e de ataque. Essas técnicas são empregadas na tentativa de evitar ou retardar a elaboração dos medos básicos. Esses medos básicos operam como uma barreira epistemologica na compreensão do objeto. Dessa forma, esses medos básicos, estabelecem um distanciamento entre objeto externo e objeto interno.

É bastante comum, por parte do grupo, a proposta de situações alternativas ao projeto, ou seja, a criação de figuras transacionais, cujo objetivo está na atenuação do conflito entre projeto e resistência à mudança - o grupo elabora suas alternativas ao projeto como se estivesse realizando a tarefa. Neste momento, pode-se observar um esquema de dissociações de sentimentos, ações e pensamentos. O grupo passa a realizar uma série de "tarefas" que lhe permitam "passar o tempo" - no entanto essa dinâmica, característica das dificuldades de entrada e finalização da tarefa, acabam por provocar uma constante frustração, que por sua vez pode vir a intensificar o estereótipo, provocando um incremento no distanciamento entre realidade e fantasia. Cabe ao coordenador evitar esse 
processo e assumir o papel prescrito pelo grupo, ou seja, o de ajudar o grupo a elaborar suas ansiedades básicas, através da comunicação e do esclarecimento, de modo a que possam superar o obstáculo epistemológico com que se deparam, afim de que possa vir a ocorrer a mudança.

Noutra alternativa, para proteger-se do sentimento de insegurança provocado pela mudança proposta pelo analista, o grupo pode se organizar, como grupo conspirador, com o objetivo de deslocar o agente da mudança - o analista, cujo papel passa a ser o de bode expiatório.

Esse processo é especialmente notável em grupos operativos de aprendizagem, principalmente na situação em que o professor propõe uma mudança de metodologia de aprendizado. O grupo sente-se ameaçado então em duas frentes: pela perda de sua estrutura anterior - de um lado, pela falta de segurança quanto aos novos procedimentos e quanto às novas atitudes, temendo pela perda de sua identidade - o que consiste no medo da perda; e, além disso, há também a questão de se contrariar o interesse individual dos alunos - o que pode ser interpretado como um medo de ataque.

Movido pela ansiedade provocada pelos dois medos básicos, o grupo tenderá a apresentar uma resistência à mudança (característica da pré-tarefa) articulando estratégias para não entrar na tarefa. Inicialmente, o grupo poderá manifestar-se contrário à mudança de metodologia, questionando a eficiência da nova metodologia, ou ressaltando a eficiência da metodologia anterior. Nesse momento, o professor deve assumir a postura de depositário desapreensivo e aceitar qualquer objeto que o grupo queira depositar nele, de modo a estabelecer e manter a comunicação, de forma a compreendê-la, interpretá-la para finalmente esclarecer ao grupo os conteúdos latentes de seus vínculos, e para que dessa forma venham descobrir quem são na realidade o professor (analista) e eles. No entanto se isto não vier a acontecer, é perfeitamente esperado que o grupo, em atitude extrema de defesa, na tentativa de deslocar o objeto propositor da mudança, passe da tática de convencimento à de ataque frontal e violento contra a nova metodologia ou mesmo contra o objeto professor, a quem o grupo adjudicou o papel de bode expiatório.

A pré-tarefa, caracterizada por esse processo de aplicação de técnicas diversivas, tentativas de retardar ou evitar a tarefa, é na verdade, um momento ordinário dentro da dinâmica grupal. No entanto, se investe de extrema relevância tendo em vista que se o coordenador, ou analista, não puder levar o grupo à análise sistemática dos fatores que impedem a aprendizagem, por um lado, tolhendo-os em termos de situar-se como sujeitos, 
e por outro lado, impossibilitando a elaboração de estratégias e táticas mediante as quais possam intervir no projeto, o grupo pode vir a reforçar o estereótipo, impedindo a mobilização e tornando a operatividade do grupo nula.

\subsubsection{A tarefa}

O sujeito entra na tarefa quando descobre que sua conduta estereotipada dificulta sua comunicação e, portanto, impede a aprendizagem da realidade. Então o sujeito modifica sua atitude em relação às mudanças propostas, apresenta-se menos resistente. Agora o sujeito está vinculado ao grupo, e o grupo como urna unidade reúne seus esforços, tanto individuais quanto grupais, no sentido da mobilização.

Esse é o momento em que o grupo aplica os fundamentos da função operativa: estratégia, tática, técnica e logística. Isto porque na tarefa, momento em que coincidem o esclarecimento, a comunicação, e a aprendizagem, é possivel resolver as situações de ansiedade.

No entanto, o fato do grupo atingir a tarefa, simplesmente, não o caracteriza como grupo operativo. Observa-se, na prática, que durante o momento da tarefa estabelecem-se fatores de complicação do processo, como por exemplo, o mal-entendido, que corresponde à situação em que ocorre uma contradição durante a comunicação entre elementos do grupo, ou a emergência de diferentes preconceitos ou ideologias, que tendem a estabelecer, no interior do grupo, subgrupos que entrarão em confrontação que poderá dificultar a realização da tarefa. Desse modo, percebe-se que para que o grupo se configure, efetivamente, em grupo operativo é necessário: que ocorra o engajamento do grupo na realização concreta de seu objetivo direto (a mobilização ou a aprendizagem) e isso constitui a tarefa explícita do grupo; e também, que o grupo supere os obstáculos surgidos a partir das contradições entre subgrupos, característicos de mecanismos de defesa ante a mudança potencial, ou seja, que o grupo sobreviva, o que constitui a tarefa implícita. Há, portanto, que se distinguir neste momento duas funções bastante distintas: a do grupo, que como já foi dito, deve atingir a categoria de pertença, cooperação, comunicação e pertinência para alcançar a realização concreta de seu objetivo direto, ou seja, a tarefa explícita; e a do coordenador, que deve garantir que o grupo supere as dificuldades provocadas pelas contradições características da formação dos subgrupos, ou seja, cabe ao coordenador assumir a tarefa implícita. 
É importante salientar que à medida que os componentes do grupo vão entrando na tarefa, ou seja, à medida que a homogeneidade da tarefa aumenta, observa-se entre eles uma diferenciação crescente, o que significa dizer que cada componente do grupo passa a representar, em cada momento, um único papel, com características de individualidade e limites próprios.

\subsubsection{O projeto}

Agora, após elaborar sua estratégia no mundo interno, o grupo pode decidir sobre seu projeto. Ou seja, o grupo passa a elaborar ou planejar o futuro e cada componente do grupo vai assumindo sua própria "nova" identidade, melhor adaptado à realidade com a qual ele interage.

Nesse processo, a tarefa vai evoluindo e se transformando em uma criação, algo novo para o grupo, algo original, no qual de equipe passam a funcionar como grupo operativo, que pelo esclarecimento, estímulos, comunicação e aprendizagem, pode obter uma produtividade que, certamente, vai muito além da de cada um de seus componentes isoladamente.

O sujeito, modificado pelo ambiente, por meio do grupo, se transforma num agente de mudança social. É a partir deste momento que o grupo se propõe novos objetivos que vão além do aqui-agora. Esse mecanismo, muitas vezes, representa uma atitude de defesa (a postergação) provocada pela ansiedade de perda que passa a afligir os componentes do grupo, ao perceber que a conclusão da tarefa pode determinar a separação do grupo.

Essa nova ansiedade pode, inclusive, levar o grupo a uma nova situação de fantasias, em conflito com a realidade equivalente à situação original. Por isso cabe ao coordenador levar o grupo a uma nova análise sistemática desse conflito e evitar esse processo esclarecendo, por um lado, sua situação como sujeitos, e de outro, a função do grupo como agente de mudança social, o que lhes possibilita a elaboração de novos projetos. Desse modo o grupo poderá se afastar de um novo estereótipo, que impediria sua mobilização e tornaria a operatividade do grupo nula.

\subsubsection{O esquema conceitual referencial operativo (E.C.R.O.)}

Usualmente, quando nos propomos a entender uma dada situação, ou então, a resolver um determinado problema, nossa tendência é a de invocar nosso conhecimento, formal ou informal, e a partir daí estabelecer ou programar uma série de procedimentos razoavelmente bem definidos, através dos quais supostamente poderemos atingir o objetivo 
previamente estabelecido. Isto é, estabelecemos de antemão um determinado procedimento operacional, imaginando que a situação/problema constitui-se de uma estrutura estática, rígida, inflexível. A esse padrão de procedimento, geralmente, damos o nome de esquema ou esquema referencial.

No entanto, o conceito de esquema referencial em sociologia, necessariamente deve agregar a noção de movimento ou evolução. Essa necessidade reside no fato de que as relações interpessoais são extremamente dinâmicas.

Devemos entender que quando um analista ou coordenador se dirige a um analisando, ele previamente pensou sua ação, e conseqüentemente aplica um esquema referencial predefinido - o que é perfeitamente admissivel e válido. No entanto, durante o processo de comunicação em que o analista tenta esclarecer a diferença entre realidade e fantasias, o analisando emite mensagens, novos emergentes, que vão modificar o esquema referencial original, dando origem a um novo esquema referencial, com o qual o analista irá interagir com o analisando no contato seguinte... e esse processo se repetirá até que o analisando compreenda os conteúdos latentes de seus vínculos, e que finalmente possa descobrir quem são na realidade o analista e ele.

Se, por um lado, o analisando é invadido pelas ansiedades de perda e de ataque em função de seus medos básicos que operam como uma barreira epistemologica na compreensão do objeto e o impelem a resistir às mudanças, por outro lado, no analista, a constante ruptura do esquema referencial, o que limita sua instrumentação, gera uma ansiedade de perda pela redução de sua operatividade além de ansiedades depressivas e paranóides.

Para Pichon-Rivière, devemos considerar um esquema referencial abrangente, que vá integrando elementos novos emergentes do processo que se estabelece na dinâmica grupal. Essa concepção implica numa libertação do analista/coordenador em relação aos seus pré-conceitos, sem o que esse analista/coordenador não será capaz de adequar de forma significativa seu esquema referencial. Cumpre então, o analista/coordenador, a função de pesquisar empiricamente, através de um processo de testes, acertos e erros, isso tudo dentro de um esquema referencial, que essencialmente deve funcionar a partir de "o de fora". 
Uma forma interessante de pensar o ECRO consiste na associação dessa dinâmica à imagem de um cone invertido (Figura 1).

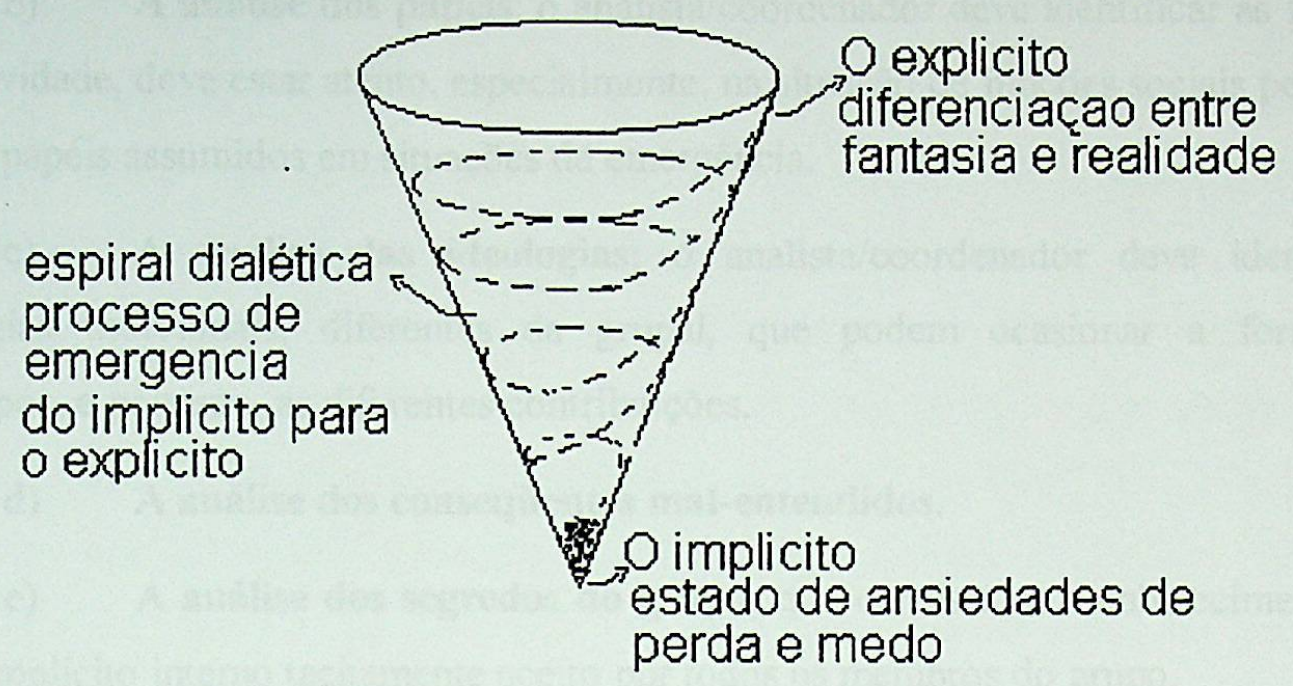

Figura 1 - Cone invertido - uma visão da dinâmica do ECRO

Como representado na Figura 1, no vértice do cone imaginam-se as situações de medo da perda da estrutura conquistada e de ataque na nova estrutura proposta, a resistência à mudança, o sentimento de insegurança, as fantasias básicas ligadas às dificuldades da mudança, ao método de superação dessas dificuldades e ao possível sucesso. Todos os componentes desta configuração (o implícito) atuam na dinâmica grupal permanentemente, e são, por isso, elementos fundamentais no trabalho do coordenador do grupo.

$\mathrm{Na}$ base do cone imaginam-se os emergentes grupais, ou seja, todas as situações manifestas durante o processo grupal, os ditos explícitos, que somente podem ser alcançados completamente quando se esclarece o problema grupal, se apontam as possibilidades de sucesso de superação do problema, se concretiza a seqüência de passos para a superação do problema e finalmente se conclui a tarefa.

E, finalmente, na espiral temos, idealmente, a dialética que se deve estabelecer para a solução do problema grupal, caracterizada por um processo contínuo de questionamentos e esclarecimentos que, a partir do explicitado pelo grupo, deve alcançar o implícito com o objetivo de explicitá-lo.

Pichon-Rivière considera que para a elaboração desse processo dialético de questionamentos e esclarecimentos, característico de um esquema conceitual referencial operativo, deve-se necessariamente incluir: 
a) $O$ conceito de porta-voz; o analista/coordenador deve estar atento ao fato de que um dos componentes do grupo vai denunciar a problemática grupal.

b) A análise dos papéis; 0 analista/coordenador deve identificar as lideranças, a rotatividade, deve estar atento, especialmente, na situação de funções sociais perturbadas, ou dos papéis assumidos em situações de emergência.

c) A análise das ideologias; o analista/coordenador deve identificar as ideologias individuais, diferentes da grupal, que podem ocasionar a formação de subgrupos, e portanto, as diferentes contribuições.

d) A análise dos conseqüentes mal-entendidos.

e) A análise dos segredos do grupo; que consiste no estabelecimento de um pacto implícito interno tacitamente aceito por todos os membros do grupo.

f) A análise dos mecanismos de desdobramento de papéis (splitting); o que corresponde aos diferentes aspectos de um mesmo papel.

g) A análise dos mecanismos de segregação e de suas infra-estruturas; ou seja, dos mecanismos empregados pelo grupo para adjudicar papéis.

h) A análise dos mecanismos de preservação; ou seja, das estratégias e táticas empregadas pelo grupo com o objetivo de resistir às mudanças.

i) As fantasias de onipotência e impotência, ordinariamente projetadas no analista/coordenador como uma tentativa de responsabilizá-lo totalmente pela solução dos problemas grupais, ou de tentar paralisá-lo.

j) A análise da situação triangular básica; ou seja a análise das representações e transferências que cada um dos vértices da relação triangular estabelece ou projeta nos demais.

k) A evolução dos meios ou logística do processo; o que eqüivale dizer a análise dos mecanismos de evolução do processo.

\subsubsection{A relação entre grupos operativos terapêuticos e grupos operativos de} aprendizagem

Em toda a obra de Enrique Pichon-Rivière, fica bastante claro, que o problema do doente psiquiátrico esta intimamente ligado à imagem que ele internaliza do objeto com o qual estabelece a relação de conflito, relação esta responsável por sua patologia. E, que sua 
proposta de terapêutica é mobilizar o doente no sentido de compreender a realidade, através de um processo de aprendizado, em que o doente possa modificar a imagem que internaliza daquele objeto.

Se aceitarmos, inicialmente, o conceito proposto por Pichon-Rivière, em que grupos operativos são conjuntos de indivíduos com um objetivo comum que procuram elaborar trabalhando como equipe, conceito este que, em nenhuma condição, limita seu universo de aplicação, e se em seguida, admitirmos que o conflito da relação pedagógica Alunos $\leftrightarrow$ Aprendizagem $\leftrightarrow$ Escola/Professor é provocado pela imagem estereotipada que o aluno internaliza dessa relação (conforme demonstrado no CAPITULO 2), poderemos assumir, o que inclusive é proposto por José Bleger (Bleger, J, 1998) e pelo próprio Pichon-Rivière, quando da realização de um curso experimental de formação de psicanalistas, que em termos conceituais, não há outra diferenciação entre grupos operativos terapêuticos e grupos operativos de aprendizagem, a não ser o tema central do aprendizado.

Em outros termos, apoiados no modelo de grupos operativos proposto por PichonRivière, podemos admitir o aluno como um indivíduo "doente", que internaliza uma imagem estereotipada do objeto de conflito, que para ele é o "conhecimento formal". E por conseqüência, a terapêutica indicada consiste em mobilizar esse aluno a compreender a realidade, através de um processo de aprendizado, até que finalmente venha a modificar a imagem que internaliza da relação Aluno $\leftrightarrow$ Aprendizagem $\leftrightarrow$ Escola/Professor. 
40

5. APRESENTAÇÃO E ANÁLISE DE CASOS 


\subsection{INTRODUÇÃO}

Neste capitulo pretendo apresentar uma série de casos de comportamento grupal, a análise de suas problemáticas, identificando os momentos em termos da teoria dos grupos operativos, como dito anteriormente, nos moldes desenvolvidos por Pichon-Rivière, minha ação sobre eles, a dinâmica grupal, e finalmente a categoria alcançada pelo grupo.

Os casos apresentados foram selecionados, a partir de um universo total de 28 (vinte e oito) casos estudados, e que a meu ver estão enquadrados no modelo estabelecido por Pichon-Rivière, por serem os casos mais representativos, isto é, os demais casos podem ser interpretados como repetições com muito pouca variação dos casos selecionados.

Está claro que se pensarmos no potencial de alunos, e portanto, de "grupos" que participaram do experimento, deveriamos ter um universo de amostragem bem maior que os 28 (vinte e oito) grupos citados no parágrafo anterior. E essa observação é, de fato, pertinente. O que ocorreu é que devido ao número elevado de grupos por aula - 5 (cinco) grupos, portanto no mínimo 20 (vinte) alunos - e conseqüente solicitação por parte desses grupos, foi muito dificil, principalmente no início do experimento, em que nossas diretrizes não estavam ainda muito bem delineadas, interagir com todos os grupos de maneira significativa, operar o manejo das situações de forma eficiente, de realizar observações sistemáticas, e principalmente efetuar a correspondente, e adequada, documentação, tendo em vista que a direção da escola na qual dispunha o maior número de casos a ser estudados não me autorizou a utilizar de câmara de vídeo ou gravador, e portanto as observações de 100 (cem) minutos de trabalho com, como já foi dito, 5 (cinco) grupos, tinham que ser registradas durante o intervalo entra as aulas, de 5 (cinco) minutos.

\subsection{CASO 1}

\subsubsection{O grupo}

Aconteceu na Escola 2, com um grupo composto de 4 alunos com idade de aproximadamente 16 anos, dois de sexo feminino ( $\mathrm{A}$ e $\mathrm{B}$ ) e dois de sexo masculino ( $\mathrm{C}$ e D). A e D eram de etnia oriental, B e C caucasiana. Além disso D tinha aparência não convencional, de visual que indica pertencer ao grupo social "clubber", bem tratado, com roupas de moda, pele bem clara, cabelos com corte "fashion" e pintados de azul celeste. 


\subsubsection{O desenvolvimento do processo grupal}

Para a abertura dos trabalhos, na primeira aula, como professor/coordenador, decidi adotar um ECRO que fortalecesse o esclarecimento básico dos passos para a realização da tarefa, que consistia na escolha de um tema de pesquisa e seu desenvolvimento, para que ao final do curso, o grupo estivesse capacitado a realizar uma apresentação do assunto para seus colegas, os demais grupos. Além disso, esse ECRO preliminar, deveria estimular os alunos de modo a que acreditassem que seria possivel concluir a tarefa com sucesso. Nesse sentido apresentei e discuti, conforme mencionado no CAPÍTULO 3, os critérios de trabalho que deveriam ser evitados pelo grupo (o contrato pedagógico), sugeri alguns temas de pesquisa, deixando bem claro que havia muitos outros temas possiveis e interessantes, e que a decisão quanto à escolha do tema de pesquisa seria da exclusiva responsabilidade deles. Forneci bibliografia inicial para pesquisa, e tentei mostrar, com exemplos reais de trabalhos apresentados por grupos de períodos anteriores, que o trabalho solicitado era perfeitamente possivel de ser realizado por eles. Além disso, com frases como...

Professor (para os alunos): - Vocês são individuos bem qualificados...-Vocês tem notas muito boas... - Os comentários que vocês estão fazendo mostram que vocês dão conta do trabalho, com facilidade...-Vocês tem mostrado nas aulas grande potencial ...

...procurei estimular todos os grupos ao trabalho.

Desde o primeiro momento, da primeira aula, o grupo deixou bem claro sua identificação com o momento da pré-tarefa, demonstrando todo tipo de dificuldade na escolha do tema de pesquisa. A todo momento, o grupo se manifestava com frases do tipo (transcrição de frases de alunos desse grupo):

Aluno C (para os demais colegas do grupo): - A gente não acha nenhum assunto legal!

Aluno A (para o professor): - O trabalho é muito dificil, e depois não tem nada nesses livros!

Aluno C (para o professor): - A gente não sabe fazer isso!

De início, demonstraram uma grande rotatividade de papéis, sem caracterizar, efetivamente, as figuras de líder ou porta-voz. 
Aluno B (para os demais colegas do grupo): - Deixa que eu vou achar um tema legal prá gente!

Logo depois...- É o seguinte, eu anoto o resumo das idéias.

Aluno A (para os demais colegas do grupo): - Gente, a gente consegue!

Logo depois... - Isso tá muito dificil!

Apenas o aluno D, se mostrava distante do grupo, sem nenhuma indicação de afiliação ou identificação ao grupo.

Professor (para o aluno D): - E então como vai indo o trabalho do grupo?

Aluno D (para o professor): - Sei lá! Num tô afim!

Professor (para o aluno D): - Mas o trabalho pode ser legal prá todos se vocês procurarem um tema de interesse do grupo.

Aluno D (para o professor): - Tá bom! Daqui a pouco eu me ligo!

Em outra ocasião...

Aluno B (para o aluno D): - D, dá uma olhada nesse capitulo!

Aluno D (para o aluno B): - Não vai dar!

A todo momento, e a todo custo, solicitavam a ajuda do professor na escolha do tema de pesquisa. Neste período com duração de três quinzenas, o grupo adjudicou ao professor o papel de onipresente. No entanto, quando pareciam demonstrar ter realizado a escolha do tema, dentro de um processo de espiral dialética ilustrado pela imagem do cone invertido, em seguida desistiam e partiam para uma nova escolha.

Aluno C (para o professor): - O trabalho é muito dificil, o senhor tem que dar mais dicas!

O grupo, quase ao mesmo tempo (para o professor): - A gente não sabe fazer isso!

Aluno B (para o professor): - Precisa de mais livros!

$\mathrm{O}$ aluno $\mathrm{C}$, representando o grupo (para o professor): - $A$ gente escolheu dilatação dos gases! O que o senhor acha?

Professor (para o grupo): - Achei muito legal. O que vocês vão explorar nesse assunto? 
Aluno B (para o professor): - Eu pensei na máquina a vapor!

Aluno C (para o professor): - Eu pensei no balão!

Professor (para o grupo): - Ótimo! Acho que já temos o caminho! Agora é o grupo trabalhar em cima disso!

Nesse momento, o professor pensou que, finalmente, o grupo havia entrado na tarefa. Mas na aula seguinte...

Aluno B (para o professor): - O trabalho tá muito dificil, a gente não achou nada em livro nenhum!

Aluno A (para o professor): - A gente não sabe fazer isso!

Aluno A (para o professor): - Acho melhor a gente procurar outro tema!

O grupo (para o professor): - Eu também acho!

Durante esse processo o professor se dirigiu diversas vezes ao grupo, apresentando várias alternativas para pesquisa, forneceu outras fontes bibliográficas, mostrou ainda que a realização do trabalho era perfeitamente viável, e que a potencialidade do grupo era mais que suficiente para sua realização. Ainda assim, não se decidiam pelo tema de pesquisa. $O$ professor pode observar, ao longo desse período, o estabelecimento de um mecanismo de segregação do aluno D pelos demais componentes do grupo, sem, no entanto, atingir niveis de expressão, ao menos aparentemente, críticos.

Aluno B (para os demais, em relação ao aluno D): - Não $C$, não adianta nada! Nem dá esse trabalho prá ele que não vai fazer!

Aluno C (para os demais, em relação ao aluno D): - É isso mesmo, a gente já viu que não adianta!

Na quinta quinzena a atitude do grupo, em relação ao professor, passou a ser quase que agressiva. $\mathrm{O}$ grupo passou a adjudicar ao professor o papel de impotente.

Aluno A (para o professor): - Esse trabalho que o senhor tá querendo tá muito dificil, a gente não acha nada em livro nenhum, a gente acha melhor mudar o esquema!

Professor (para o grupo): - Vocês já perceberam que escolheram vários assuntos muito legais? Lembram da máquina a vapor? Super legal! Era só ser mais persistentes e pesquisar com dedicação. Olha esse livro, por exemplo! Fala sobre a máquina a vapor! Já 
é um começo! Vocês não acham que só precisam se decidir a fazer? Capacidade prá isso vocês já mostraram que tem.

Aluno A (para o professor): - A gente faz uma pergunta e você não ajuda!

Aluno C (para o professor): - É você não ajuda! Você complica! E pergunta outra coisa que não tem nada a ver!

Professor (para o grupo): - Gente! Vamos fazer mais outra tentativa. Vamos procurar um tema legal. Vamos achar um caminho que todos vocês concordem! Quando resolverem isso me chamem! Vamos ao trabalho!

Por outro lado, muito embora o aluno D se mostrasse socialmente polido, no relacionamento com seus colegas de grupo e professor, estabelecia um distanciamento pouco comum entre colegas de escola. Um fato, bastante interessante, desse período de trabalho, é que durante os diálogos que o professor manteve com o aluno $\mathrm{D}$, embora sempre respondesse educadamente, o aluno mantinha-se lacônico, emitindo frases curtas, e sempre evitando olhar diretamente para o professor. Além disso, mostrava uma grande indiferença e desprezo com relação ao trabalho em grupo - e aqui poderíamos identificá-lo em seu papel individual como mundano.

Aluno D (para o grupo e professor): - Não adianta fazer isso, não tão vendo que não vai dar certo? Isso é muito dificil prá gente!

Em outra ocasião, durante um dos momentos de escolha de um possivel tema...

Aluno D (para o grupo): - Estudar a dilatação de uma ponte? Que besteira? Não serve prá nada...

Inicialmente, durante o estabelecimento do mecanismo de segregação do aluno $\mathrm{D}, \mathrm{o}$ grupo, aparentemente, não se importava com a atitude desse aluno, era como se simplesmente o houvessem isolado; no entanto, à medida que as atitudes diversivas do grupo em sua tentativa de evitar a entrada na tarefa, em sua resistência à mudança, foram se esgotando, o grupo passou a responsabilizar a falta de colaboração do aluno $\mathrm{D}$, por essa dificuldade.

Aluno B (para o professor): - O trabalho já tá dificil, e o D não ajuda a gente!

Aluno A (para o professor): - D além de não ajudar, atrapalha!

Aluno B (para o professor): - Se D não ajudar a gente, não vai dar! 
sua vez, o aluno D, no papel de bode expiatório, passou inclusive, aparentemente, sem o menor constrangimento, a acumular as dificuldades de todo o grupo.

Aluno B (para o professor): - Se D não ajudar a gente, não vai dar!

Aluno D (para o grupo): - Não tô nem ai!

Esse novo emergente certamente deveria representar um importante incremento ao ECRO. Muito embora, por fora, o aluno D se mostrasse distante e indiferente, ao interagir mais freqüentemente com ele, o professor, assumindo o papel de depositário desapreensivo, percebeu, sua necessidade de comunicação, ou seja, a necessidade do aluno em depositar parte dele no professor, depositário. Essa necessidade ou tendência foi estimulada pelo professor dando maior abertura à comunicação, pelo aumento de número de interações e até mesmo pela abordagem de assuntos não diretamente ligados à tarefa, ou mesmo a atividades escolares.

Professor (para o aluno D): - D, que você faz fora da escola?

Aluno D (para o professor): - Muitas coisas.

Professor (para o aluno D): - Você faz algum tipo de esporte?

Aluno D (para o professor): - Isso não!

Professor (para o aluno D): - Então, que você faz?

Aluno D (para o professor): - Há! Eu toco numa banda!

Professor (para o aluno D): - Legal! Você toca o que?

Aluno D (para o professor): - Eu toco teclado!

Professor (para o aluno D): - Teclado?! E a bando toca o que?

Aluno D (para o professor): - Como o que!

Professor (para o aluno D): - Que tipo de música?

Aluno D (para o professor): - A gente toca de tudo!

Professor (para o aluno D): - Tem outros alunos da escola na tua banda?

Aluno D (para o professor): - Não o pessoal é amigo de fora! Não acho legal misturar as estações.

Professor (para o aluno D): - Você pretende seguir na música? 
Aluno D (para o professor): - Sei lá! Eu gosto, mas sou mais afim de desenho, eu faço desenho industrial, sabe?

\section{Professor (para o aluno D): - Muito legal!}

Note-se que durante esse diálogo, bem característico dessa fase, no início o aluno D se manifesta com repostas curtas, impessoais, evasivas, deixando claramente que não tem interesse na conversa. Mas, à medida que a conversa se estende e ele percebe o interesse do professor, passa a participar mais ativamente da conversa. Fica perfeitamente claro nessa transcrição a progressiva mudança de atitude do aluno diante do professor. $\mathrm{O}$ professor também observou que o aluno passou a olhar diretamente para ele, professor, durante essas conversas. Nesse processo, muito provavelmente, foi ocorrendo a quebra da imagem estereotipada do professor, internalizada pelo aluno D. Tanto, que após duas ou três quinzenas, duração da fase mais aguda desse processo (é relevante considerar que havia, pelo menos, mais quatro grupos na sala de aulas e, portanto, a necessidade da divisão das atenções do professor), o aluno $\mathrm{D}$ havia revelado ao professor várias particularidades, desconhecidas até pelos colegas de classe. Citaremos, aqui, apenas, as que consideramos explicitamente relevantes para a análise da situação. $\mathrm{O}$ aluno $\mathrm{D}$ informou ao professor que era independente economicamente e que trabalhava como designer de motivos góticos especificamente para decalques para tatuagens.

A questão era: como interpretar esse depósito, parte do aluno $\mathrm{D}$, no sentido de quebrar esse seu estereótipo de resistência à mudança e de mobiliza-lo para a tarefa? Como identificar o "insight" que levaria o aluno D ao salto qualitativo para a tarefa? A expectativa era de que essa potencial mudança no aluno $\mathrm{D}$ fizesse com que os demais componentes do grupo se vissem cara a cara com a realidade e que, finalmente, também entrassem num processo de mobilização. Nesse momento, inclusive, o professor solicitou à psicóloga da escola mais informações relativas ao perfil comportamental do aluno $\mathrm{D}$, que pudessem ser úteis para acessá-lo de forma significativa. No entanto, nada havia na ficha individual do aluno que apontasse para uma estratégia específica que viesse a colaborar no sentido de mobilizá-lo dessa atitude.

Dentro do conceito de incrementos à ECRO, e com contínuo estímulo de espiral dialética durante, por pelo menos mais 3 (três) quinzenas, o professor interagiu com o grupo, sempre na tentativa de manter aberto o canal de comunicação entre componentes do grupo e professor. Ainda durante esse período, o grupo apresentava grande indefinição na escolha do tema, pouca produtividade, a tarefa (na verdade estavam ainda na pré-tarefa) se 
arrastava, apresentavam uma grande rotatividade de papéis, exceto o de bode expiatório adjudicado pelo grupo ao aluno $\mathrm{D}$, que por sua vez, continuava não colaborando.

Apresentamos a seguir a transcrição de alguns trechos de diálogo, característicos desse momento:

Aluno B (para o grupo): - Gente, o tempo tá passando e a gente não achou o tema ainda!

Daí a poucos minutos...

Aluno B (para o grupo): - Sabe de uma coisa? Esse tipo de trabalho é muito chato. $\mathrm{Na}$ quinzena seguinte...

Aluno B (para o grupo): - Eu tenho uma sugestão ótima. Eu li na Superinteressante sobre um forno solar!

A essa altura do processo, apesar de estar plenamente convencido da necessidade da descoberta de um "insight" para a entrada do aluno D na tarefa, o pesquisador via-se lançado numa situação de práticamente total impotência, e tomado por dúvidas e angústias que certamente dificultavam a compreensão da realidade.

Além disso, a evolução do grupo parecia indicar que não entrariam no processo de mobilização desejado, situação que se agravava, especialmente com o aluno D, que agora, apesar da mudança de atitude em relação ao professor, passara a assumir diante do grupo o papel de obstrutor.

Aluno D (para o grupo): - Não, isso não vai dar certo!

Em outro momento...

Aluno D (para o grupo): - Não vai dar prá eu fazer não!

Sempre na tentativa de manter a comunicação com os componentes do grupo, na décima quinta quinzena, o professor se dirigiu ao grupo e com o objetivo de estimular o aluno $\mathrm{D}$, perguntou aos membros do grupo se tinham lido uma reportagem veiculada naquela semana sobre o tema tatuagem, segundo a qual a tatuagem com o uso de agulhas e tintas faziam parte do passado, agora a moda era a tatuagem a fogo.

$O$ aluno $\mathrm{D}$ deu início a um questionamento aberto e franco, em que não demonstrava nenhum tipo de inibição ou restrição. Ele queria saber tudo sobre esse novo processo de tatuagem, sobre o qual ela nunca havia ouvido falar - como era o processo, 
Quase que imediatamente à assunção da liderança pelo aluno $\mathrm{D}$, os demais membros do grupo passaram a assumir o papel de obstrutores numa tentativa de negar liderança ao aluno D...

Aluno B (para o professor): - Pô, professor, o cara fica aí sem fazer nada o tempo todo e agora vem dando ordem!

Aluno A (para o professor): - Eu não vou trabalhar assim não!

Aluno B (para o professor): - O D tá muito mandão!

Aluno C (para o professor): - Eu não quero esse tema de tatuagem a ferro quente não!

...e, dessa forma, não entrar na tarefa, o que retornava o grupo à situação de uma dinâmica grupal absolutamente equivalente à situação do doente mental e sua família, ou seja resolvido o problema do doente, um ou vários outros membros da família podem adoecer.

\section{Comentários}

Podemos concluir, portanto, que no início do processo, o aluno $D$, devido a suas características individuais (para Pichon-Rivière, o membro dinamicamente mais forte do grupo) fez-se depositário do problema coletivo do grupo, e assumiu o papel de porta-voz do problema grupal.

Como coordenador, procurei, novamente, redirecionar o ECRO, de modo a minimizar a segregação e as individualidades que se estabeleceram no grupo, através de estímulos ao grupo, que de forma geral tinham como objetivo mostrar que, unidos e trabalhando em grupo, seria perfeitamente possivel realizar a tarefa.

Professor (para o grupo): - Gente, agora todos estão afim de fazer o trabalho, não é mesmo? Então? Vamos deixar o passado prá lá, e vamos começar a trabalhar! $O D$ conhece de tatuagens, não é mesmo? Vocês estudaram Termologia por vários meses, porque não juntam tudo isso e fazem um trabalho totalmente novo, de interesse de vocês todos do grupo e dos demais colegas da classe! Não vai ser demais?

Aluno C (para o professor): - Tá, mas o D tem que ir devagar!

Professor (para o grupo): - Bom, isso vocês é que tem que resolver entre vocês mesmos, não acham? 
Nesse período, o grupo iniciou um processo claro de organização interna. No início desse processo houve alta rotatividade de papéis entre o membros do grupo (menos o aluno $\mathrm{D}$, que sempre conservou a liderança), no entanto à medida que o tema do trabalho ia se definindo para o grupo, pudemos observar a diminuição da rotatividade de papéis.

\begin{tabular}{|c|c|c|c|c|c|}
\hline \multicolumn{6}{|c|}{ QUADRO DE ANALISE EVOLUTIVA } \\
\hline \multicolumn{6}{|c|}{ QUANTO AO PROCESSO GRUPAL } \\
\hline $\begin{array}{c}\text { Afiliação } \\
\text { ou } \\
\text { Identificação } \\
\end{array}$ & Pertença & Cooperação & Pertinência & Aprendizagem & Telê \\
\hline & & $X$ & & & \\
\hline \multicolumn{6}{|c|}{ QUANTO Aं TAREFA } \\
\hline \multirow{2}{*}{\multicolumn{2}{|c|}{ Pré tarefa }} & & & \multicolumn{2}{|c|}{ Projeto } \\
\hline & & \multicolumn{2}{|c|}{$X$} & & \\
\hline \multicolumn{6}{|c|}{$\begin{array}{l}\text { Comentários } \\
\text { Nesse momento era bastante clara a efetiva integração dos componentes do grupo e sua } \\
\text { entrada na tarefa. A rotatividade inicial e contínua de papéis deixava claro a mobilização do } \\
\text { grupo e sua entrada no processo de cooperação. }\end{array}$} \\
\hline
\end{tabular}

Ao final, faltando 3 (três) quinzenas para o término do curso, o grupo trabalhava em alta produtividade, cada componente realizando suas funções, compartilhando os resultados obtidos com os demais componentes... colaborando de forma positiva com o trabalho grupal.

Aluno C (para o grupo): - Bom gente, durante essa semana eu reescrevi o texto que nós combinamos, lembra? Eu fiz uma cópia prá cada um. Vamos dar uma lida, aí a gente discute como ficou!

QUADRO DE ANALISE EVOLUTIVA

QUANTO AO PROCESSO GRUPAL

\begin{tabular}{|c|c|c|c|c|c|}
\hline $\begin{array}{c}\text { Afiliação } \\
\text { ou } \\
\text { Identificação }\end{array}$ & Pertença & Cooperação & Pertinência & Aprendizagem & Telê \\
\hline & & & $X$ & & \\
\hline
\end{tabular}


apresentação deixaram de forma bem clara que haviam alcançado um nivel de profundidade no tema além do previsto na proposta inicial - que podemos interpretar como projeto.

Após a conclusão do curso, o aluno $D$, se decidiu a fazer um curso de joalheria. Todos os componentes do grupo continuam na escola, cursando a $3^{a}$ série do ensino médio. Conforme informações de professores que continuam com esses alunos, seus resultados acadêmicos melhoraram significativamente, especialmente em atividades que envolvem análise, crítica e avaliação de situações.

Em nosso entender a dinâmica que se estabeleceu no grupo permite enquadrá-lo como excelente exemplo de grupo operativo. Pudemos observar a passagem pelo momento da prétarefa, tarefa e projeto, a dinâmica dialética envolvida nesse processo, a evolução dos papéis, a formação de estereótipos, de estruturas individuais, a segregação, a necessidade de incremento do ECRO, e finalmente a configuração como grupo operativo.

\subsection{CASO 2}

\subsubsection{O grupo}

O grupo estudado esteve composto de 4 alunos com idade de aproximadamente 18 anos, todos de sexo feminino, que identificaremos por (E, F, G e H). E e F eram de etnia afro-brasileira, G e H caucasiana. Este caso ocorreu na Escola 1.

\subsubsection{O desenvolvimento do processo grupal}

Da mesma forma que para todas as aulas aplicadas na Escola 1, na abertura dos trabalhos, como professor/coordenador, como estratégia de ECRO, apresentei um evento que levasse os grupos, naquela aula, ao questionamento - nesse caso foi discutido o experimento imaginário em que o pesquisador mergulha inicialmente sua mão esquerda num recipiente contendo água fervendo, mergulha sua mão direita num outro recipiente contendo cubos de gelo e em seguida retira as mãos desses recipientes e as mergulha simultaneamente num terceiro recipiente contendo água morna. Pergunta-se então, qual a sensação que cada uma das mãos vai associar à água morna? Como já descrito anteriormente, a função desta atividade é dar o "start" ao pensar e à ação. Em seguida, entregamos a cada grupo uma lista de questões com o objetivo de normatizar o grupo, ou seja, tratavam-se de questões conceituais que pretendiam colocar o aluno diante de situações conflitantes de modo que viesse a questionar seus conceitos espontâneos, 
estabelecer um fio condutor para o aprendizado, criar condições para discussão em grupo, promover a tomada de funções do sujeito no grupo, estimular a pesquisa individual e em grupo, propor modificações em seus conceitos espontâneos até que finalmente, e idealmente, o grupo chegue ao modelo científico aceito.

O grupo cujo desenvolvimento será descrito como CASO 2 participou deste momento com apenas três componentes (aluno $\mathrm{E}$, aluno $\mathrm{F}$ e aluno $\mathrm{G}$ ), o quarto componente somente esteve presente a partir da segunda aula (ou seja, na semana seguinte).

Num momento inicial, dessa primeira aula, a conduta dos componentes presentes do grupo, me surpreendeu profundamente (posso afirmar isto porque já trazia uma certa bagagem adquirida devido à atuação na Escola 2, e nunca observara esse padrão de conduta, tão cristalizado, logo na primeira aula), e mergulharam num processo organizado de pesquisa (segue o relato de algumas passagens dessa aula):

...após a leitura do questionário...

Aluno F (para o grupo): - Gente, eu não sei nem como começar!

Aluno G (para o grupo): - Shi! Eu também não. O que que a gente faz?

Aluno F (para o grupo): - Bom! O barato é começar a procurar nos livros que o professor deu prá gente usar!

Aluno E (para o grupo): - Pô mas é livro pacas! Qual a gente pega?

Aluno G (para o Aluno E): - Ué! Parece que é boba! Tá boba é?

Aluno F (para o Aluno E): - Tá boba mesmo!

Aluno G (para o Aluno E): - Cada uma pega um, e tenta achar a resposta!

Aluno E (para o grupo): - E ai a gente junta as respostas!

Aluno F (para o grupo): - É isso ai! Vamos organizar o trabalho, senão não vai render!

Aluno E (para o grupo): - Tá legal! Vamos começar a procurar!

...a partir desse momento o grupo, aparentemente, se fechou, completamente, no trabalho de pesquisa... 


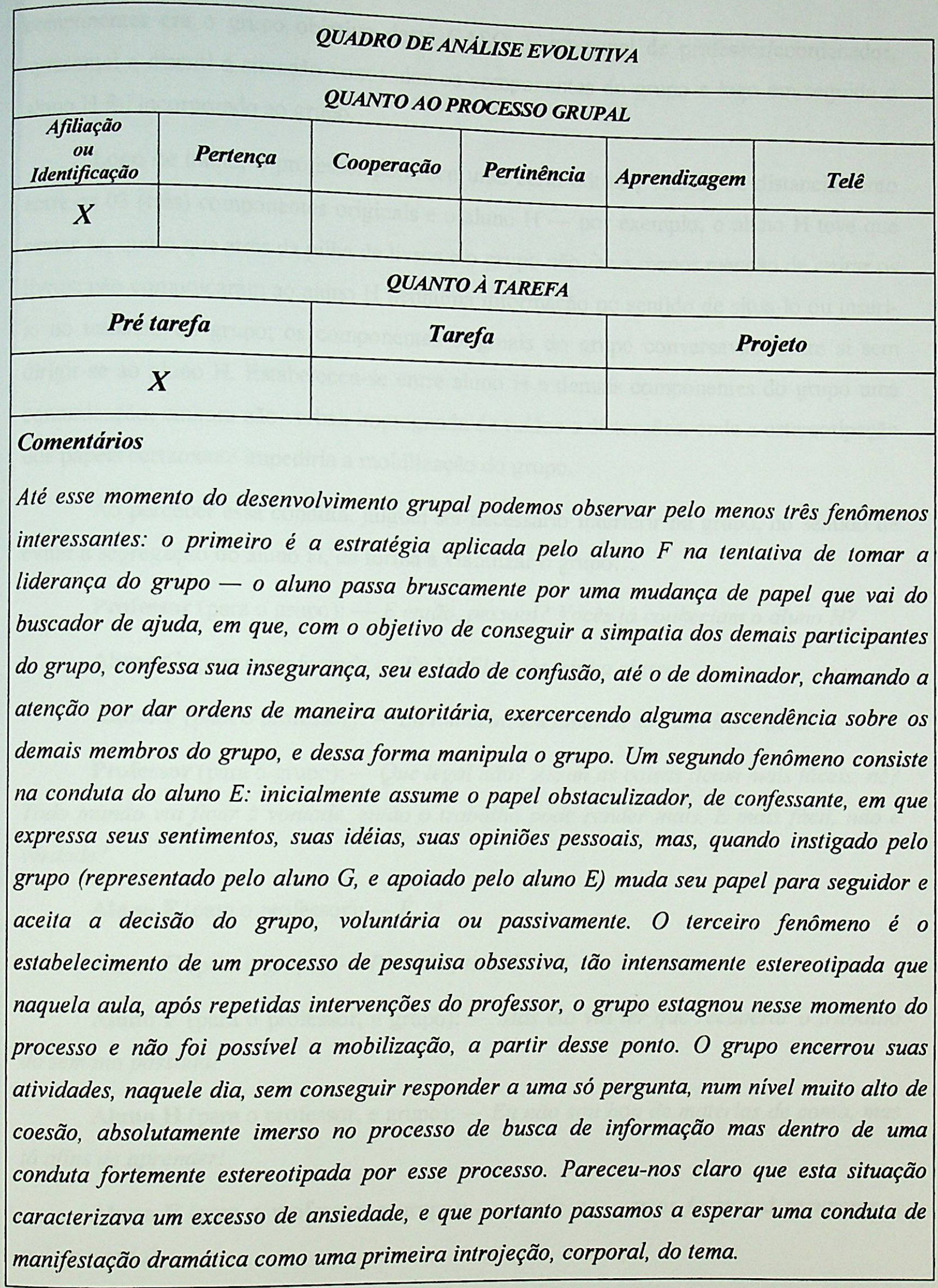

$\mathrm{Na}$ aula seguinte, uma semana depois, logo após os alunos terem formado seus grupos originais de trabalho, antes do início dos trabalhos, ocorreu a adesão de mais um aluno à turma - o aluno $\mathrm{H}$. Como o único grupo da turma com apenas 03 (três) 
componentes era o grupo objetivo deste CASO 2, no papel de professor/coordenador, apresentei e discuti a situação com todos os componentes do grupo e logo em seguida o aluno $\mathrm{H}$ foi incorporado ao grupo.

Logo de inicio, o professor percebeu uma certa atitude, velada, de distanciamento entre os 03 (três) componentes originais e $\mathrm{o}$ aluno $\mathrm{H}$ - por exemplo, o aluno $\mathrm{H}$ teve que sentar-se, quase que atrás da pilha de livros e o grupo não fez a menor menção de retirar os livros; não comunicaram ao aluno $\mathrm{H}$ nenhuma informação no sentido de situa-lo ou inserilo no trabalho do grupo; os componentes originais do grupo conversavam entre si sem dirigir-se ao aluno $\mathrm{H}$. Estabeleceu-se entre aluno $\mathrm{H}$ e demais componentes do grupo uma comunicação, embora não verbal, impregnada de ruídos e distorções, onde a estereotipação dos papéis certamente impediria a mobilização do grupo.

Ao perceber essa conduta, julguei ser necessário interferir no grupo, no sentido de evitar a segregação do aluno $\mathrm{H}$, de forma a viabilizar o grupo...

Professor (para o grupo): - E então, pessoal? Vocês já conheciam o aluno H?

Aluno G (para o professor): - Eu já! Ela é da minha classe.

Aluno F (para o professor): - Eu também! Eu também sou da classe dela.

Professor (para o grupo): - Que legal não? Assim as coisas ficam mais fáceis, né? Todo mundo vai ficar à vontade, então o trabalho pode render mais. É mais fácil, não é verdade?

Aluno F (para o professor): - É...!

Aluno G (para o grupo): - Por mim, tudo bem!

Aluno F (para o professor, e grupo): - Mas ela vai ter que recuperar o trabalho da semana passada!

Aluno H (para o professor, e grupo): - Eu não sou boa de matérias de conta, mas tô afins de aprender!

Aluno F (para o professor, e grupo): - Como nos vamos fazer prá recuperar a aula passada?

Professor (para o grupo): - Bom, vocês conhecem as regras de nosso trabalho, não é mesmo? O que interessa para o grupo é que todo o grupo ande junto prá frente, e não só esse ou aquele, lembram? Agora vocês ajudam o aluno $H$, ela fica conhecendo o 
trabalho, e dai ela também vai poder ajudar o grupo! Dai prá diante o trabalho de cada um no grupo fica mais fácil! Concordam?

Aluno F (para o professor, e grupo): - Eu concordo!

Aluno $\mathbf{G}$ e aluno $\mathbf{E}$ (para o professor, e grupo):- Eu também!

...nesse momento o professor esperava ter ajudado o grupo no sentido de superar a segregação em relação ao aluno $\mathrm{H}$, fator que possivelmente viria a causar a estagnação do grupo.

Num primeiro momento, me pareceu que essa interferência sobre o grupo havia sido eficaz - de pronto, os componentes do grupo iniciaram um processo de comunicação entre si, em que aparentemente tratavam da integração do aluno $\mathrm{H}$. Inclusive houve uma pausa no processo de aquisição de informação, no qual estavam estagnados desde a aula anterior. Mas após, aproximadamente 30 minutos de atividades, o aluno $\mathrm{F}$ me chamou...

Aluno F (para o professor): - Professor, nós estamos tentando explicar o que a gente fez na semana passada prá ela aí, (apontando para a aluno H), mas não dá, ela não quer entender!

Aluno H (para o professor, e grupo): - Eu tô tentando! Mas eu avisei que não sou boa de contas!

QUADRO DE ANALISE EVOLUTIVA

QUANTO AO PROCESSO GRUPAL

\begin{tabular}{|c|c|c|c|c|c|}
\hline $\begin{array}{c}\text { Afiliação } \\
\text { ou } \\
\text { Identificação }\end{array}$ & Pertença & Cooperação & Pertinência & Aprendizagem & Telê \\
\hline$X$ & & & & \\
\hline \multicolumn{3}{|c|}{ QUANTO À TAREFA } \\
\hline Pré tarefa & Tarefa & Projeto \\
\hline$X$ & &
\end{tabular}

\section{Comentários}

É interessante notar que até aquele momento não haviam efetivamente iniciado a solução de nenhuma das questões da lista e portanto não haviam entrado, ainda, na tarefa. Ou seja, de inicio, na primeira aula, o grupo assumiu uma postura estereotipada de busca obsessiva de 
informação que "impedia" sua mobilização, e agora, na segunda aula, ainda na tentativa de evitar a tarefa, adjudicavam ao aluno $H$ o papel de bode expiatório, e por sua vez, o aluno $H$ assumia o papel adjudicado pelo grupo. O grupo resistia dessa forma à mobilização.

Professor (para o grupo): - Gente, como é que vão as questões? Quantas vocês já responderam?

Aluno F (para o professor), apontando para a aluno $\mathrm{H}:-$ Quantas?! A gente não respondeu nenhuma não! Não tá dando! A gente tem que explicar tudo prá H!

Aluno E (para o professor): - Assim demora muito! A gente não consegue fazer mais nada!

Percebendo a orientação que o grupo tomava, como professor/coordenador, em continuidade ao ECRO, no sentido de evitar a perda da comunicação entre os componentes do grupo, e entre o grupo e professor, e sentindo-me responsável, ao menos parcialmente, pelo processo resolvi interferir mais uma vez, no sentido de facilitar com que grupo superasse essa situação...

Professor (para o grupo): - Bom, vocês conhecem as regras de nosso trabalho, não é mesmo? O que interessa para o grupo é que todo o grupo ande junto prá frente, $e$ não só esse ou aquele, lembram? Agora vocês ajudam o aluno $H$, ela fica conhecendo o trabalho, e dai ela também vai poder ajudar o grupo! Dai prá diante o trabalho de cada um no grupo fica mais fácil! Concordam?

Aluno F (para o professor): - Bom, se a gente pensar assim é melhor mesmo! Mas H tem que acompanhar a gente! A gente não sabe nem prá gente. Não dá prá ficar explicando tudo!

Aluno G (para o professor, e grupo): - É isso mesmo. Não dá prá ficar explicando o tempo todo, só porque ela perdeu a primeira aula, agora a gente paga o pato prá ela.

Professor (para o grupo):- Gente, não esqueçam que a união faz a força. Quando a aluna $H$ ficar em dia com o assunto ela pode ser uma bruta mão na roda, prá dividir o trabalho! Agora é com vocês!

Aluno E (para o grupo): - Bom gente, o professor tem razão. Vamos tentar de novo!

Aluno F e aluno G (entre si, com expressão de estar meio a contra gosto): - Tá bom...! 


\section{Comentários}

As feições e expressões corporais apresentadas pelos componentes iniciais do grupo inquietação, movimentos nervosos, olhares reprovadores para o aluno $H$, não olhavam diretamente para o professor quando se dirigiam a ele, essa comunicação não verbal assinalavam que eu não havia efetivamente conseguido convencê-los a aceitar a presença do aluno $H$ e muito menos a trabalhar com eles. Por outro lado, aluno $H$ aceitava, com naturalidade, o papel de bode expiatório adjudicado pelo grupo. Do ponto de vista da tarefa o grupo permanecia completamente imobilizado, em sua estratégia diversiva, reforçando sua atitude estereotipada de responsabilizar o aluno $H$ pelo não andamento da tarefa.

Durante toda aquela segunda aula o grupo se manteve nessa atitude: na superficialidade "tentavam ajudar" o aluno H no sentido de atualizá-lo no trabalho grupal; no entanto, a todo momento, interrompiam o processo, chamando o professor para se queixar da atitude do aluno $\mathrm{H}$, afirmando que ela não colaborava, que ela não entendia nada, e até mesmo...

Aluno F (para o professor, sobre o aluno H): - Pô, professor assim tá dificil. Não dá prá ficar explicando tudo! Ela parece burra!

O evoluir do grupo evidenciava, claramente, o estabelecimento de uma intensa segregação do grupo em relação ao aluno H. E, como professor/coordenador, eu não conseguia reverter ou ao menos atenuar esse processo. Aquela aula terminou sem que o grupo, mesmo após várias interferências minhas, conseguisse se mobilizar dessa atitude.

\section{Comentários}

Durante a semana que se seguiu análisei os dados obtidos com o grupo, revi dados obtidos de outros grupos com os quais trabalhara e que apresentaram condutas semelhantes, pesquisei bibliografia, na tentativa de perceber algo na orientação que o grupo tomava, que pudesse incorporar ao ECRO, afim de evitar a segregação entre os componentes do grupo. Estava claro, para mim àquela altura, que se o grupo continuasse com aquela orientação a extinção do grupo seria inevitável. Era absolutamente necessário a descoberta de um "insight" que, de alguma forma, estabelecesse a comunicação entre os componentes do grupo - única real possibilidade de reversão do processo.

Esse processo despertava em mim, no papel de professor/coordenador, uma ansiedade, 
movida pela possível perda do grupo, que estava dificil de elaborar. Esse grupo era o primeiro grupo a resistir de forma tão intensamente estereotipada à mobilização.

No entanto a continuidade desse processo grupal foi surpreendente... 0 aluno $\mathrm{H}$ não compareceu à aula da semana que se seguiu.

\section{Comentários}

Essa ausência possivelmente teve conseqüências contundentes para o grupo, que se viu sem bode expiatório através do qual justificava a não entrada na tarefa.

Essa nova situação pela qual não esperavam levou todos os componentes presentes a um estado de dramatização tão intenso que não era viável nem o questionamento nem a aprendizagem. Seguem alguns trechos de dialogo desse momento...

Aluno G (profundamente irritada, para o grupo): - Agora o negócio vai ficar dificil! Estamos com o trabalho atrasado, porque ficamos explicando prá $H$, e ela não aparece, e não dá prá dividir trabalho. Agora é que eu quero ver!

Comentários

Note-se a tentativa de manter o aluno H como bode expiatório, ainda que ausente...

Percebendo a persistência do grupo, resolvi interferir mais uma vez, no sentido de facilitar com que grupo superasse essa situação...

Professor (para o grupo): - Então pessoal? Hoje $H$ não veio! Vocês sabem porque?

Aluno G (para o professor): - Eu não sei! Mas deve ser por causa da greve de ônibus. Muita gente não tá vindo à escola!

\section{Comentários}

...de fato naquele momento passávamos por uma greve coletiva de ônibus.

Professor (para o grupo): - E então? O trabalho hoje vai render? Como é que é?

Aluno F (para o professor): - É hoje deve ser mais fácil! $H$ estava atrasando muito a gente. Hoje a gente vai recuperar.

Professor (para o grupo): - Então vamos nessa! Já sabem! Qualquer dúvida, qualquer dificuldade é discutir com o grupo. Depois de discutido, e todo mundo ter apresentado suas idéias, se a dúvida continuar, me chama que eu discuto com vocês! 


\section{Comentários}

...nesse momento, por mais uma vez, imaginei ter estimulado a mobilização do grupo. No entanto o que se seguiu a esse momento foi novamente uma estereotipia de busca de informação, semelhante àquela da aula inicial, porém, ainda, mais obsessiva, a ponto de desencadear um processo de diálogo, sem motivação ou objetivo claro, e que na verdade indicava uma total falta efetiva operatividade.

Seguem alguns trechos de dialogo desse momento..

Aluno E (para o professor): - Assim demora muito! A gente não consegue fazer mais nada!

Aluno F (transtornada, para o grupo): - Olha, hoje não tô dando prá nada. Não consigo nem ler nem pensar! Nada!

Aluno G (para o aluno F): - Pára de falar um pouco, que eu tô lendo um negócio importante.

Instantes depois...

Aluno G (para o grupo): - $\dot{E}$... hoje não tô afins! Não consigo entender nada!

Esse padrão de diálogo sem propósito específico permaneceu até o final daquela aula, mesmo após a minha interferência por sucessivas vezes, todas sem sucesso.

\section{Comentários}

Por mais uma vez, a conduta do grupo em questão, tipicamente de resistência à tarefa mediante a transferência da responsabilidade para bode expiatório, me levou a rever $e$ reanalisar todos os dados obtidos do grupo, a pesquisar novas bibliografias, na expectativa de descobrir qualquer nova informação que pudesse evitar a extinção do grupo que parecia iminente.

$\mathrm{Na}$ aula da semana seguinte: nova surpresa! - não compareceram os alunos $\mathrm{E}, \mathrm{G}$, nem $H$. Esteve presente apenas a aluna $F$.

Logo no início da aula, em momento oportuno, quando não estava sendo observada pelos demais colegas, o professor perguntou à aluna $\mathrm{F}$ se sabia do porque da ausência das colegas: a aluna $F$ respondeu de forma evasiva, quase monossilábica, e sem olhar diretamente para o professor... 
Aluno F (alterada, para o professor): - Não sei!... Ontem eu vi elas... Ninguém me falou nada... Não tô sabendo..

\section{Comentários}

Conhecendo o histórico do grupo (especialmente em termos de coesão entre seus componentes, excluida, é claro a aluna H) estava convencido de que diante dessa situação, somente havia duas alternativas: dispensar a aluna $F-o$ que significaria muito provavelmente a extinção do grupo - ou, integrar a aluna $F$ (que assumia o papel de lider) em um outro grupo de trabalho, na expectativa de que essa aluna, ao perceber a possibilidade concreta de realizar a tarefa, convencesse as demais a retornar ao curso.

Tentei, no papel de professor/coordenador, integrar a aluna $\mathrm{F}$ em um outro grupo que se desenvolvia de forma perfeitamente ajustada.

A tentativa se mostrou em vão..

Aluno F (totalmente desconfortável, para o professor): - Professor! Não é melhor eu não assistir a aula hoje e voltar com todo mundo na semana que vem? Eles estão muito práfrente!

Professor (para o Aluno F): - Olha $F$, você sabe muito bem que a decisão é sempre de vocês. Eu acho que você deve pensar muito bem!. Você é uma aluna competente, responsável e determinada. Então você deve pensar bem como você vai aproveitar melhor o tempo de hoje! Claro que do ponto de vista do teu grupo o trabalho de hoje não vai ajudar muito, mas para você como individuo... você pode estudar um pouco... você pode ver como esse grupo, que você está agora, trabalha... sei lá, você pode ter ótimas idéias para repartir depois com teu grupo.

Aluno F (a contragosto, para o professor): - Tá bom professor! Eu vou tentar, mas eu acho que não vou conseguir acompanhar esse grupo. Eles já começaram a lista três, e nós nem começamos a lista um. Não vai dar não!

Professor (para o Aluno F): - Como eu te disse, a decisão é sempre de vocês. Eu acho que ficando você sempre pode aprender alguma coisa, ou sobre a matéria, ou sobre como trabalhar em grupo, mas é você que sabe.

Aluno F (ainda a contragosto, para o professor): - Tá bom! Vou continuar, mas acho que não vai adiantar! 


\section{Comentários}

Neste momento, mergulhado numa ansiedade provocada pela possivel perda do grupo, eu estava convencido a tentar aproximar o aluno $F$ do novo grupo, muito mais para "ganhar tempo", na expectativa de que na aula seguinte o grupo original voltasse às aulas, visto que efetivamente passávamos por um periodo de greves nos transportes coletivos (muito embora não houvessem ocorrido ausências tão numerosas nos demais grupos) que propriamente para que o aluno $F$ efetivamente se integrasse ao novo grupo.

É interessante descrever o processo de tentativa de integração do aluno $\mathrm{F}$ com o novo grupo: no início, o aluno $\mathrm{F}$ efetivamente tentou participar das atividades do novo grupo dentro do mesmo padrão de atitudes que representava no grupo original, ou seja, líder dominador..

Aluno F (para o novo grupo): - Gente vocês não acham que esse texto que vocês escreveram tá muito esquisito? Eu li ele todinho e não entendi nada! Eu acho que tinha que mudar muita coisa!

No entanto, o novo grupo reagiu energicamente contra a conduta apresentada pelo aluno $\mathrm{F}$...

Aluno X (um dos componentes do novo grupo para o aluno $\mathrm{F}$ ): - $O$ que que você achou esquisito?

Aluno F (para o aluno X, do novo grupo): - Ah! Sei lá! Eu não entendi! Eu acho que tem que mudar!

Aluno X (irritado, para o aluno F): - Olha! Esse material que você tá lendo agora, nos já discutimos e acertamos tudo já faz duas semanas. Agora a gente tá lá na frente, você tá chegando agora, não vai querer fazer a gente voltar tudo prá trás, né?!

Aluno F (para o aluno X do novo grupo): - Tá bom! Então tudo bem!

O que se seguiu foi um processo de auto segregação, ou auto isolamento por parte do aluno $F$. Após a reação violenta do novo grupo, que não admitiu sua tentativa de obstrução, o aluno F percebeu e assimilou seu isolamento no novo grupo. Durante restante do período daquela aula permaneceu sem realizar nenhuma outra tentativa de interação com o novo grupo. 


\section{Comentários}

Por mais uma vez, durante a semana que se seguiu, a conduta estereotipada do grupo objetivo deste caso, e do aluno $F$, em particular, me fizeram reler e repensar o desenvolvimento grupal (tendo em vista que em nenhum outro caso pude observar um processo de estereotipia tão intenso), na expectativa de enxergar qualquer informação que tivesse passado antes despercebida, e que pudesse ajudar a evitar a extinção do grupo, que a cada aula, me parecia mais clara.

$\mathrm{Na}$ aula seguinte ocorreu o que já esperava... nenhum dos componentes do grupo compareceu.

Finalmente o grupo assumiu sua extinção.

\begin{tabular}{|c|c|c|c|c|c|}
\hline \multicolumn{6}{|c|}{ QUADRO DE ANALISE EVOLUTIVA } \\
\hline \multicolumn{6}{|c|}{ QUANTO AO PROCESSO GRUPAL } \\
\hline $\begin{array}{c}\text { Afiliação } \\
\text { ou } \\
\text { Identificação }\end{array}$ & Pertença & Cooperação & Pertinência & Aprendizagem & Telê \\
\hline & $X$ & & & & \\
\hline \multicolumn{6}{|c|}{ QUANTO À TAREFA } \\
\hline \multicolumn{2}{|c|}{ Pré tarefa } & \multicolumn{2}{|c|}{ Tarefa } & \multicolumn{2}{|c|}{ Projeto } \\
\hline \multicolumn{4}{|c|}{$X$} & & \\
\hline \multicolumn{6}{|c|}{$\begin{array}{l}\text { Comentários } \\
\text { O relato acima parece nos levar à conclusão de que estamos diante de um caso típico de } \\
\text { grave estereotipia na resistência à mobilização a partir de um "status" anterior, mais } \\
\text { confortável. }\end{array}$} \\
\hline \multicolumn{6}{|c|}{$\begin{array}{l}\text { Possivelmente o contato inicial do grupo com a informação configurou-se em algo tão intenso } \\
\text { que não puderam expressar-se a não ser pela dramatização, exatamente por ser um processo } \\
\text { primitivo. E, para justificar a não tomada de ação adjudicaram ao aluno H o papel de bode } \\
\text { expiatório; no entanto, a ausência do aluno } H \text { os fez deparar-se com a origem real das } \\
\text { dificuldades que encontravam. Possivelmente, esta realidade se negavam a ver, tenha } \\
\text { provocado a ausência de E e G, na semana seguinte à ausência de H. Por outro lado, muito } \\
\text { provavelmente, a continuidade de F estivesse ligada a uma tentativa de manter o "status" de } \\
\text { liderança. Como, no entanto, o novo grupo não admitiu essa possibilidade, o aluno F também }\end{array}$} \\
\hline
\end{tabular}


se negou a ver essa realidade e não compareceu mais às aulas.

Muito embora, o grupo não tenha entrado na tarefa, ainda assim a meu entender, atingiu um desenvolvimento grupal equivalente à pertença, se considerarmos o grau de integração $e$ segurança alcançado pelos componentes do grupo (exceto o aluno $H$ ).

Este caso foi apresentado por dois motivos fundamentais para a compreensão do processo grupal: devido a sua importância em termos de aprendizado quanto a condutas fortemente estereotipadas, e para destacar a importância do professor coordenador, no sentido de abrir $e$ manter o canal de comunicação adequado à expressão do grupo, já que sem a disponibilização desse canal o grupo entra, como vimos, num processo de exacerbação de estereótipos, acaba fechando-se em si mesmo, e finalmente se extingue.

\subsection{CASO 3}

\subsubsection{O grupo}

Tratou-se de um grupo composto por 4 alunos, da $2^{\mathrm{a}}$ série do Ensino Médio da Escola 2. A idade desses alunos era de aproximadamente 16 anos.

Havia três alunos de sexo feminino ( $\mathrm{I}, \mathrm{J}$ e K) e um aluno de sexo masculino (L). Todos caucasianos e de aparência convencional. Seu visual indicava não pertencer nenhum grupo social específico - ou tribo, na linguagem utilizada pelos adolescentes.

No primeiro momento, devido à minha "experiência" adquirida durante o acompanhamento de diversos outros grupos anteriores, minha sensação era a de que esse grupo muito pouco contribuiria para este trabalho...

\subsubsection{O desenvolvimento do processo grupal}

Em cumprimento à estratégia preliminar adotada em nossa proposta de pesquisa, já apresentada no CAPÍTULO 3, para a abertura dos trabalhos, na primeira aula, tratei de orientar, os alunos quanto aos passos básicos para a realização da tarefa, como por exemplo, sugeri alguns temas de pesquisa, deixando bem claro que havia muitos outros temas possíveis e interessantes, e que a decisão quanto à escolha do tema de pesquisa seria de exclusiva responsabilidade deles. Insisti no fato de que a escolha do tema de pesquisa, e seu desenvolvimento, era decisão deles, como alunos-pequisadores, mas, que sempre deveriam levar em conta que, ao final do curso, o grupo deveria estar capacitado a realizar uma apresentação do assunto para seus colegas, os demais grupos. Apresentei e discuti, as 
condutas que deveriam ser evitados pelo grupo (o contrato pedagógico), e, além disso, tratei de estimula-los, de modo a que acreditassem que seria possivel concluir a tarefa com sucesso. Também, disponibilizei alguma bibliografia para "dar a partida" à pesquisa, e tentei mostrar (da mesma forma que para todos os outros grupos), com exemplos reais de trabalhos apresentados por outros grupos, de periodos anteriores, que o trabalho solicitado era perfeitamente possível de ser realizado por eles.

Estabelecidas essas condições iniciais, ainda na primeira sessão, tratei de avaliar, mesmo que informalmente, quais seus conceitos preestabelecidos, em termos de estudo do Calor (já que era o assunto em pauta). Após uma breve discussão - bastante positiva quanto à diferença entre calor, energia térmica e temperatura, o grupo deu início ao trabalho de escolha do tema de pesquisa.

Durante o tempo restante dessa primeira sessão, todos os componentes do grupo, sem exceção, adotaram uma conduta surpreendentemente democrática, demonstrando uma certa organização e interesse no processo de pesquisa do tema a ser escolhido. Havia uma comunicação franca e dinâmica entre os componentes, e não foi possivel perceber fortes tendências no sentido de assumir a liderança, conforme ilustrado no diálogo abaixo que corresponde a uma transcrição de um dos momentos dessa primeira sessão...

Aluno J (para os demais colegas do grupo): - Olha, pessoal! Este artigo mostra um assunto que eu acho bem legal! Vocês não querem dar uma olhada?

Aluno I (para o aluno J): - Legal! Você pode explicar prá gente esse assunto? Se a gente achar bom, então a gente lê e vê com mais certeza!

Aluno J (para os demais colegas do grupo): - Tá bom! O assunto é o ...

...e seguiu-se a apresentação do assunto, de forma organizada, dentro de um padrão de comunicação bastante adequado à formação desses alunos. Os demais, prestavam atenção à explanação do aluno $\mathrm{J}$. Houve algumas dúvidas, que o aluno $\mathrm{J}$ não soube explicar, então os demais se apressaram em ler trechos do texto, tentando obter a explicação. Somente depois de algumas tentativas, eu fui chamado a intervir. Após minha intervenção o grupo retomou a discussão, e o processo se reiniciou. Essa dinâmica se prolongou até o final da primeira sessão, sem que, no entanto tivessem se decidido pelo tema de pesquisa. 


\begin{tabular}{|c|c|c|c|c|c|}
\hline \multicolumn{6}{|c|}{ QUADRO DE ANALISE EVOLUTIVA } \\
\hline \multicolumn{6}{|c|}{ QUANTO AO PROCESSO GRUPAL } \\
\hline $\begin{array}{c}\text { Afiliação } \\
\text { ou } \\
\text { Identificafão }\end{array}$ & Pertença & Cooperação & Pertinência & Aprendizagem & Telê \\
\hline$X$ & & & & & \\
\hline \multicolumn{6}{|c|}{ QUANTO À TAREFA } \\
\hline \multicolumn{2}{|c|}{ Pré tarefa } & \multicolumn{2}{|c|}{ Tarefa } & \multicolumn{2}{|c|}{ Projeto } \\
\hline \multicolumn{2}{|c|}{$X$} & & & & \\
\hline \multicolumn{6}{|c|}{$\begin{array}{l}\text { Comentários } \\
\text { Este momento parece indicar o estabelecimento de uma dinâmica grupal positiva, onde todos } \\
\text { os componentes do grupo interagem entre si, sem apresentar estereótipos, e com o objetivo de } \\
\text { escolha do tema de pesquisa, ou seja, o grupo parece se mobilizar no sentido de entrar na } \\
\text { tarefa. }\end{array}$} \\
\hline
\end{tabular}

Na sessão seguinte (após uma quinzena) os alunos retornaram à aula e reiniciaram, normalmente, o trabalho de seleção do tema de pesquisa. De início tudo evoluiu dentro de um quadro previsível. Todos trabalhavam na leitura e discussão de textos (alguns haviam sido trazidos por eles próprios e mostravam aos demais) num processo de rotatividade de papéis, mas todos com caracteristicas positivas.

No entanto, quase ao fim dessa sessão, comecei a perceber no grupo (sem dar, nesse momento, grande importância), duas condutas bastante curiosas: muito embora, efetivamente, estivessem realizando um bom trabalho de busca de seu tema de pesquisa, e já tivessem, até mesmo, discutido e selecionado de maneira, inclusive, organizada, diversos temas, comecei a observar que o grupo não conseguia se decidir pelo tema, por outro lado, o aluno L (o único rapaz do grupo) começava a adotar o papel de buscador de reconhecimento, ou seja, tratava de atrair, constantemente, a atenção sobre si, atuando sempre de maneira forçada, conduzindo a comunicação do grupo para suas qualidades ou gostos pessoais. 


\begin{tabular}{|c|c|c|c|c|c|}
\hline \multicolumn{6}{|c|}{ QUADRO DE ANALISE EVOLUTIVA } \\
\hline \multicolumn{6}{|c|}{ QUANTO AO PROCESSO GRUPAL } \\
\hline $\begin{array}{c}\text { Afilią̧ão } \\
\text { ou } \\
\text { Identificafão }\end{array}$ & Pertença & Cooperação & Pertinência & Aprendizagem & Telê \\
\hline & & $X$ & & & \\
\hline \multicolumn{6}{|c|}{ QUANTO À TAREFA } \\
\hline \multicolumn{2}{|c|}{ Pré tarefa } & \multicolumn{2}{|c|}{ Tarefa } & \multicolumn{2}{|c|}{ Projeto } \\
\hline \multicolumn{2}{|c|}{$X$} & & & & \\
\hline \multicolumn{6}{|c|}{$\begin{array}{l}\text { Comentários } \\
\text { Aparentemente, os componentes do grupo já estavam "envolvidos" no processo, a ponto de } \\
\text { todos estarem contribuindo com o grupo. Já se podia observar uma dinâmica de papéis que } \\
\text { identifica, por um lado a operatividade do grupo, e por outro, o conflito (centrado no aluno L) } \\
\text { entre a verticalidade do sujeito e a horizontalidade do grupo-caracteristicas da cooperação. } \\
\text { A partir desse momento, eu imaginava que logo entrariam na tarefa, começariam a elabora-la } \\
\text { e, posteriormente, conclui-la. }\end{array}$} \\
\hline
\end{tabular}

$\mathrm{Na}$ quinzena seguinte (sessão seguinte) os alunos retornaram, novamente, à aula e reiniciaram, normalmente, o trabalho de seleção do tema de pesquisa.

Desta vez, o grupo começou a solicitar minha presença muito seguidamente e muitas vezes, e sempre para o atendimento a dúvidas individuais. Em todas essas minhas interferências relembrei, sem sucesso, a todos os componentes do grupo a questão da socialização das dúvidas, que havia sido proposta quando da apresentação do "contrato pedagógico". Foi um processo curioso observar que no discurso deles "entendiam e concordavam" com o contrato pedagógico, mas, logo em seguida, solicitavam novamente minha presença, sem preliminarmente ter discutido a possível dúvida. Vejamos a transcrição de uma dessas conversas...

Aluno K (para o professor): - Professor, como é mesmo o processo de aquecimento de uma estufa? $O$ vidro é transparente prá luz, mas é opaco prá qual tipo de onda?

Professor (para os alunos, especialmente para o aluno K ): - Bem, gente! Eu acho que o aluno I pode explicar isso prá nós, não é mesmo I? Não faz 15 minutos eu expliquei, algo semelhante, naquele caso do aquecimento da Terra, lembra? E eu usei como outro 
exemplo o caso da estufa, está lembrado I? Como vocês são alunos bem competentes tenho certeza que vão conseguir discutir o assunto e entender tudo! Agora gente, outra coisa! Que foi que nós acabamos de conversar, com relação a isso de perguntar para o professor sem discutir primeiro no grupo? Vocês estão vendo? Esse assunto já foi discutido com I, e o L está sabendo... Vocês concordaram em, antes de chamar o professor, primeiro, discutir no grupo, até esgotar as possibilidades! Mas um dos componentes do grupo chama o professor quando o colega pode ajudá-lo na dúvida! Não foi o que acertamos, né?

Aluno K (para o professor e grupo): - É mesmo, professor, foi mal! Mas é que a gente não se acostuma! A gente vai tentar, né, pessoal?

Como podemos verificar eles "compreendem" o contrato e o "aceitam", mas logo em seguida (não se passaram sequer 10 minutos)..

Aluno K (para o professor): - Professor, dá pro senhor vir aqui que tô com uma divida?

Professor (para o alunoK): - Já discutiram o assunto no grupo? Todos estão por "dentro" da dúvida?

Aluno K (para o professor): - Não, professor, é coisa rápida...

Como podemos ver o processo se reinicia novamente. Isso ocorreu muitas e muitas vezes naquela e nas aulas seguintes.

Paralelamente o grupo não se decidia pelo tema de pesquisa... e o motivo não era a falta de temas, ao contrário, o grupo estava bem organizado - haviam montado uma pasta com os temas organizados em uma dada ordem, onde estavam incluídas cópias xerográficas de textos e fotos relativas a cada um dos temas pré-selecionados. E, além disso, a atitude do aluno L, a cada sessão, se estereotipava, cada vez mais, no papel de buscador de reconhecimento.

\begin{tabular}{|c|c|c|c|c|c|}
\hline \multicolumn{7}{|c|}{ QUADRO DE ANÁLISE EVOLUTIVA } \\
\hline \multicolumn{5}{|c|}{ QUANTO AO PROCESSO GRUPAL } \\
\hline $\begin{array}{c}\text { Afiliação } \\
\text { ou } \\
\text { Identificação }\end{array}$ & Pertença & Cooperação & Pertinência & Aprendizagem & Telê \\
\hline & & $X$ & & & \\
\hline
\end{tabular}




\begin{tabular}{|c|c|c|}
\hline \multicolumn{3}{|c|}{ QUANTO À TAREFA } \\
\hline Pré tarefa & Tarefa & Projeto \\
\hline$X$ & & \\
\hline $\begin{array}{l}\text { Comentários } \\
\text { Já estávamos na } 5^{a} \text { se } \\
\text { resiste à mobilização, } \\
\text { Além disso, comece } \\
\text { dificuldade, ou seja, } \\
\text { Por considerar que e } \\
\text { aluno L, imaginei q } \\
\text { possivel reverter esse }\end{array}$ & $\begin{array}{l}\text { aparente } \\
\text { itude diver } \\
\text { o grupo } \\
\text { me adjud } \\
\text { icio com c } \\
\text { re o alun } \\
\text { rma viabi }\end{array}$ & $\begin{array}{l}\text { do no processo grupal, } \\
\text { ir se decidir pelo tema. } \\
\text { ponsabilizar por essa } \\
\text { utor e até de agressor. } \\
\text { nduta estereotipada do } \\
\text { ver a realidade, seria } \\
\text { upo à mobilização. }\end{array}$ \\
\hline
\end{tabular}

$\mathrm{Na} 6^{\mathrm{a}}$ sessão, aguardei uma oportunidade para abordar, junto ao grupo, essa questão do papel de buscador de reconhecimento apresentada pelo aluno $\mathrm{L}$.

No momento em que novamente fui requisitado para o esclarecimento de uma determinada dúvida, em que ficou perfeitamente claro, para todos os componentes do grupo, que não havia sido discutida entre eles, questionei a conduta de cada uma dos componentes do grupo, conforme a transcrição que se segue...

Professor (para o grupo): - E então, gente? Já se passaram 5 aulas, vocês aí com um belo trabalho nas mãos, já faz um tempão, e não se decidem pelo tema de pesquisa! Vocês estão vendo que o grupo está amarrado, não se desenvolve! Ficam pedindo explicações, direto, sem trabalhar sobre as dúvidas! Que está havendo, gente! Será que não é hora de repensar e discutir a conduta de cada um dos membros do grupo? Se está havendo a colaboração de cada um? Vocês lembram da primeira aula? Aquela coisa de condutas que contribuem positivamente para o grupo, e outras que amarram o desenvolvimento do grupo! Não seria uma boa idéia analisar os papéis que cada um de nós está assumindo no grupo? Se é positivo ou não?

\section{Comentários}

Apesar da estagnação do grupo, sua conduta geral me levava a crer que após essa conversa, eles pensariam e discutiriam sua atitude, o que daria, ao menos, uma abertura para sua mobilização. 
No entanto a reação foi exatamente o oposta à esperada...

Aluno J (para o professor): - Professor, o senhor está querendo dizer que a gente não quer fazer o trabalho de propósito?

Aluno K (para o professor): - A gente faz o que pode! A gente se esforça bastante! Olha quanta coisa a gente já pesquisou!

Aluno J (para o professor): - Pô! Só porque a gente pergunta? A gente não sabe tudo!

Aluno L (para o professor): - É isso ai! Eu tenho a maior dificuldade e elas ai me ajudam toda hora!

\section{Comentários}

Essa reação do grupo - que eu não esperava - reforçada pelo discurso do aluno L, repetido em outras oportunidades daquela e das sessões seguintes, configuraram um momento do desenvolvimento grupal em que me foram, claramente, adjudicados os papéis de agressor e bode expiatório, pela impossibilidade do grupo na escolha do tema de pesquisa ou seja pela entrada na tarefa. Eu passei a ser o depositário de toda a responsabilidade pela estagnação do grupo.

Em resumo, minha interferência, cujo objetivo foi o de fazer com que o grupo reavaliasse sua conduta, de modo a que pudessem ver a realidade, acabou provocando uma forle coesão do grupo, numa atitude negativa, de estagnação e de distanciamento da realidade. Isso, além de ter introduzido um forte ruido na comunicação entre eles e eu, como professor/coordenador.

Apesar dessas dificuldades, as experiências anteriores já me haviam convencido de que no processo grupal a manutenção da comunicação e a aceitação do papel de depositário desapreensivo são elementos fundamentais das técnicas de manejo de grupos, sem o que o grupo certamente entra num ciclo fechado e viciado pela estereotipia.

Portanto, a partir daquele momento, meu trabalho passou a ser $o$ de buscar novas alternativas de comunicação.

$\mathrm{Na} 7^{\text {a }}$ sessão, passei a observar mais atentamente o grupo na expectativa de uma oportunidade de intervir no grupo, e abrir novas linhas de comunicação. Durante essa sessão pude observar uma coesão interna, muito forte, entre os componentes do grupo, em torno do aluno $\mathrm{L}$, que passava a assumir o papel de dominador. 
Se essa coesão era tão forte assim, talvez fosse possível aproveitá-la para reorientar o grupo no sentido da mobilização.

Foram necessárias algumas sessões para reverter esse processo de estagnação: na $9^{a}$ sessão o grupo discutia a questão das paredes de gelo dos "iglus"...

Aluno I (para os colegas): - Prá que as paredes se o gelo dos blocos vai ficar na temperatura lá de fora?

Aluno K (para o aluno I): - Não é isso não o gelo vai manter a temperatura de zero graus!

Aluno I (para o aluno K): - Quer dizer que não tem gelo abaixo de zero graus?

Aluno L (para os colegas): - Vamos mudar de assunto, que esse ai tá pegando!

Aluno I (para os colegas): - Não! Vamos chamar o professor que eu tô curioso dis.so!

\section{Comentários}

$\dot{E}$ interessante comentar que já havia algumas sessões que o grupo muito dificilmente solicitava a minha interferência, como que numa atitude de represália àquela em que, na $\sigma^{a}$ sessão tentei fazê-los enfrentar seu problema básico.

Como nesse momento eu estava atento ao que se passava no grupo, logo que solicitado interferi, de modo a dar-lhes condições para que compreendessem o mecanismo da condução térmica. E como no laboratório (local em que aconteciam essas sessões) tínhamos equipamentos para realizar experimentos sobre condução térmica, propus ao grupo - com o objetivo de melhorara sua compreensão sobre o tema e de re-estabelecer a minha comunicação com eles - que realizassem o experimento.

A reação do aluno $L$, foi negativa...

Aluno L (para os colegas): - Pô! Isso não vai dar é em nada! A gente nem sabe se vai ser essa a nossa pesquisa! Vamos perder o maior tempo!

No entanto...

Aluno I (para os colegas): - Que nada! Deve ser super legal, a gente apresentar uma experiência no nosso trabalho! 
Comentários

Percebi o estabelecimento de um impasse entre o aluno $I$ e o aluno L. Tratava-se, possivelmente, um principio de disputa pela liderança.

Minha intenção, naquele momento, era viabilizar e manter a comunicação com o grupo. De modo que interferi, novamente, para que esse processo de disputa interna não viesse a dificultar, ainda mais, o desenvolvimento do grupo.

Professor (para o grupo): - E então, gente? Qual é a decisão do grupo? Vamos fazer o experimento? O equipamento é bem fácil de montar! E a experiência não demora nada! No minimo, vai dar prá saber se o assunto é, ou não, legal! Afinal eu vi que vocês estavam super interessados na casa dos esquimós!

Aluno J (para os colegas): - Pô! Vamos fazer o experimento! A gente não tem mais nada prá hoje! E. fazer experiências sempre é legal!

Como todos concordaram, inclusive o aluno $\mathrm{L}$, forneci o equipamento necessário, e o grupo começou a estudar a propagação de calor através de sólidos, em diferentes materiais.

\section{Comentários}

O experimento consiste em aquecer com a chama de uma vela hastes de materiais diferentes. Nestas hastes são fixados, com parafina, “clips" para papel, ou mesmo alfinetes.

Observando que os "clips" se soltam das hastes em instantes diferentes, conclui-se a existência de materiais que conduzem melhor ou pior o calor.

Após a observação do comportamento de alguns sólidos quanto à condução térmica, o grupo estava completamente envolvido com o experimento e com o assunto. $\mathrm{O}$ tema passou a ser um desafio assumido pelo grupo, e estavam dispostos a superá-lo Discutiam de forma organizada, procuravam bibliografia que lhes desse suporte teórico. Já estavam conscientes da diferença entre bom e mau condutor de calor, e que, de modo geral, metais são bons condutores de calor. Quando o grupo estava prestes a testar o comportamento do latão...

Aluno L (para os colegas): - A gente não vê o uso de latão em equipamentos que trabalham com calor, o pessoal usa aço, ferro. O latão deve ser mau condutor! 
Professor (para o grupo): - Essa sua observação é muito importante. Realmente, em tecnologia, a gente não vê muito a aplicação do latão em equipamentos que operam com calor. Mas eu acho que vocês deveriam pensar mais um pouco nessa questão antes de afirmar que o latão é necessariamente um mau condutor de calor. Vocês querem ver? Que tipo de material é o cobre? Já fizemos o teste com o cobre!

Aluno L (respondendo): - O cobre é sólido!

Professor (para o aluno L e grupo): - De fato, em nossa experiência utilizamos o cobre na forma sólida! Era uma barrinha de cobre! Mas o cobre pode ser encontrado, por exemplo na forma liquida?

Aluno I (respondendo): - Eu nunca vi, mas acho que pode! É só derreter!

Professor (para o grupo): - É isso mesmo! Basta fornecer energia suficiente, para aumentar a temperatura até o ponto de fusão do cobre...

Aluno L (com ansiedade, interrompendo minha interferência): - $O$ que é ponto de fusão?

\section{Comentários}

Comecei a perceber que à medida que minha comunicação com o grupo ia se restabelecendo, o aluno L ia assumindo atitudes físicas de inquietação e desconforto, que demonstravam sua insatisfação com aquele desenvolvimento.

Professor (para o grupo): - O ponto de fusão do cobre é a temperatura na qual o cobre passa de sólido para liquido, ou seja, derrete!

Aluno L (ainda demonstrando com ansiedade): - E a que temperatura o cobre derrete?

Professor (para o grupo): - Essa resposta eu não sei de cabeça! Mas vou procurar me informar e trago de volta prá vocês! Agora, eu posso afirmar que a temperatura de fusão de um material, não é única, ou seja para cada pressão, há uma temperatura de fusão! Assim, por exemplo, em Santos a temperatura de fusão do cobre é um pouco maior que em São Paulo!

\section{Comentários}

Não pude deixar de notar a satisfação do aluno $L$, com o fato de eu não saber responder, de pronto, à sua pergunta. 
Isso confirmou minha suspeita de que o aluno L disputava, comigo, o dominio sobre o grupo

Dando continuidade.

Professor (para o grupo): - Então, a resposta que $L$ deu à pergunta que fiz: Que tipo de material é o cobre?, deve ser respondida não com seu estado físico? Não é mesmo? O cobre pode ser sólido, pode ser liquido, e até gás! Eu gostaria que vocês me respondessem, na verdade, qual o tipo de estrutura desse material, o cobre?

Aluno I (respondendo): - Bom, será que a resposta é que o cobre é metal?

Professor (para o grupo): - $\dot{E}$ isso mesmo o cobre apresenta uma estrutura cristalina, isto é, seus átomos estão distribuidos de uma forma muito bem definida, que denominamos estrutura metálica. Dessa forma dizemos que o cobre é um metal. Vejam ele apresenta alta densidade, rigidez, e em nosso experimento ele se mostrou bom condutor de calor, não é mesmo?

0 grupo (respondendo, quase que ao mesmo tempo): - É mesmo!

Professor (para o grupo): - Bom! Agora vamos falar do material testado! Qual foi mesmo?

O grupo (respondendo, quase que ao mesmo tempo, agora até o aluno L participou): - Foi a barrinha de aluminio!

Professor (para o grupo): - Que vocês podem me falar sobre o aluminio?

Aluno L (demonstrando certo cinismo): - Que é sólido!

Professor (para o aluno L): - É verdade, a barrinha de aluminio é sólida! E o que mais?

Aluno L (mantendo o cinismo): - Que é metal!

Professor (para o aluno L, e para o grupo): - Muito bem! A barrinha de aluminio é sólida, e o aluminio é um metal! Eo que mais?

O grupo (respondendo, quase que ao mesmo tempo, inclusive o aluno $\mathrm{L}$ participou): - $O$ aluminio é bom condutor!

Professor (para o grupo): - Muito legal! É claro que testamos poucos materiais para afirmar isso, mas vejam: o cobre é metal e é bom condutor, o aluminio é também metal e bom condutor, então que devemos esperar do latão que também é metal? 
Aluno L (para os colegas, cinicamente): - Que o latão deve ser mau condutor!

0 aluno $L$ percebendo o retorno da comunicação do grupo, reagia, agora de forma estereotipada, na tentativa de não perder o dominio sobre o grupo.

Professor (para o aluno L): - Mas L, pensa bem, é claro que não fizemos o experimento, mas as informações que nós temos até o momento, nos levam a crer que todo metal é hom condutor! Não é mesmo?

Aluno L (para os colegas, cinicamente): - Não concordo!

Professor (para o grupo): - Então qual é o caminho?

Aluno L (para os colegas, cinicamente): - Sei lá!

Professor (para o grupo): - O procedimento cientifico é realizar o experimento, para verificar o que acontece!

Aluno L (para o grupo e professor): - Eu sei o que acontece!

Professor (para o aluno L): - Então diz prá nós o que acontece!

Aluno L (para o grupo e professor): - Nós vamos aquecer a barra de latão com a vela, e o calor não vai se espalhar pela barra, os alfinetes não vão cair!

Professor (para o aluno L): - Mas L, o latão é metal e metal é bom condutor de calor!

\section{Comentários}

Percebendo falta de argumentos, e que inevitavelmente fariamos o experimento que mostraria seu equívoco, o aluno L, na tentativa estereotipada de não perder o dominio sobre o grupo, lançou um desafio....

Aluno L (para o grupo e professor): - Para provar que eu estou certo, vamos aquecer a barra de latão com a vela, e eu vou segurar a outra ponta com a mão, vocês vão ver que o calor não vai se espalhar pela barra. Eu não vou queimar a mão!

Professor (para o aluno L): - Mas $L$, se você não estiver certo você vai queimar sua mão! Não é melhor fazer o experimento com os alfinetes? 
Comentários

Aqui fica clara a conduta estereotipada do aluno $L$, que na tentativa de preservar o dominio sobre o grupo, preferia correr o risco fisico de se queimar, imaginando que mesmo que o latão fosse bom condutor poderia suportar a dor provocada pela queimadura, à perda do dominio sobre o grupo.

Aluno L (para o grupo e professor): - Se agente usar alfinetes, eles podem cair por outro problema, e eu não quero ter dúvida! Depois eu tenho certeza do que tô falando!

Permiti que se realizasse a experiência, imaginando que logo que a temperatura da ponta da haste em sua mão aumentasse um pouco, o aluno $\mathrm{L}$, imediatamente soltaria a haste, e seria forçado reconhecer a verdade,

O surpreendente foi constatar que o aluno L suportou o aumento de temperatura durante muito tempo, alguns minutos, sem demonstrar dor. Evidentemente, para evitar possiveis danos físicos, eu tive que interromper o experimento.

No entanto o aluno $L$ teve que se deparar com a realidade. $O$ experimento comprovou que o latão era bom condutor de calor, porque o aluno ao suportar a temperatura da barra por tanto tempo, havia queimado seriamente a ponta dos dedos.

A atitude estereotipada do aluno $\mathrm{L}$, e suas conseqüências, pode ser observada tanto pelos demais componentes do grupo, como até mesmo de outros grupos, e fizeram com que percebessem a importância de manter um bom nível de comunicação, aberto, franco, bem como uma conduta dinâmica e equilibrada.

Imediatamente após esse evento dramático, o aluno $\mathrm{L}$ foi acolhido carinhosamente, pelos demais componentes do grupo.

Pude observar, que apesar do ambiente "carregado" que se estabeleceu no grupo, não houve tentativas de diminuir ou ridicularizar a atitude do aluno $\mathrm{L}$, nem pelos seus colegas de grupo, nem mesmo dos demais grupos.

Aos poucos, nas sessões seguintes, o grupo, agora sem a atitude dominadora do aluno $\mathrm{L}$, foi superando as dificuldades esperadas.

$\mathrm{Na} 11^{\mathrm{a}}$ sessão, finalmente, fizeram a escolha do tema de pesquisa e estabeleceram a partir daí uma dinâmica de trabalho fundamentada em colaboração, troca de informações 
comunicação, integração, equilibrio, ausência de conflitos, de ansiedades, enfim estavam aptos a concluir a tarefa à qual tinha se proposto.

Em mais algumas sessões, a pesquisa estava pronta

Na semana anterior à apresentação, fui procurado pelo grupo (estavam presentes, todos os componentes do grupo), fora do horário regular das sessões, para a realização de uma prévia. É interessante destacar que, da mesma forma que com muitos outro grupos, fui solicitado a avaliar a apresentação, não dentro de um caráter de colaborador, em termos de conteúdo simplesmente, mas, como avaliador crítico. Pude sentir perfeitamente que haviam aprendido a caminhar com suas próprias pernas.

\begin{tabular}{|c|c|c|c|c|c|}
\hline \multicolumn{6}{|c|}{ QUADRO DE ANALISE EVOLUTIVA } \\
\hline \multicolumn{6}{|c|}{ QUANTO AO PROCESSO GRUPAL } \\
\hline \multirow[t]{2}{*}{$\begin{array}{c}\text { Afiliação } \\
\text { ou } \\
\text { Identificação } \\
\end{array}$} & Pertença & Cooperação & Pertinência & Aprendizagem & Telê \\
\hline & & & & $\boldsymbol{X}$ & \\
\hline \multicolumn{6}{|c|}{ QUANTO À TAREFA } \\
\hline \multirow{2}{*}{\multicolumn{2}{|c|}{ Pré tarefa }} & \multicolumn{2}{|c|}{ Tarefa } & \multicolumn{2}{|c|}{ Projeto } \\
\hline & & \multicolumn{2}{|c|}{$X$} & & \\
\hline \multicolumn{6}{|l|}{ Comentários } \\
\hline \multicolumn{6}{|c|}{ Em minha análise do desenvolvimento grupal identifico duas fases bastante distintas: o antes } \\
\hline \multirow{2}{*}{\multicolumn{6}{|c|}{$\begin{array}{l}\text { do confronto com o aluno L, onde o grupo mostra um inicio de desenvolvimento, considerado } \\
\text { normal, ou seja, a fase da identificação, em que os componentes do grupo começam a se } \\
\text { aproximar e estabelecer um vinculo entre si. Logo a seguir o momento da pertença, em que o }\end{array}$}} \\
\hline & & & & & \\
\hline \multicolumn{6}{|c|}{ grupo adquire um certo nivel de confiança, ou segurança, de uns nos outros, e no processo, e } \\
\hline \multirow{2}{*}{\multicolumn{6}{|c|}{$\begin{array}{l}\text { portanto é possivel planejar e estabelecer critérios. Logo em seguida pudemos observar a } \\
\text { cooperacão. com todos os componentes trabalhando para o bem do grupo, com rotatividade }\end{array}$}} \\
\hline \multirow{2}{*}{\multicolumn{6}{|c|}{$\begin{array}{l}\text { de papéis, que por um lado caracteriza a operatividade do grupo, mas por outro, a } \\
\text { possibilidade de conflitos entre a verticalidade do sujeito e a horizontalidade do grupo. }\end{array}$}} \\
\hline & & & & & \\
\hline \multicolumn{6}{|c|}{$\begin{array}{l}\text { Eossibilidade de conflitos entre a verticallamente esse padrão de conflito que interrompe o processo. } O \text { aluno L, começa a } \\
\text { assumir o papel de buscador de reconhecimento e, em seguida quando se vê ameaçado, } \\
\text { assume o papel de dominador. Essa conduta acaba por estagnar a eventual mobilização do }\end{array}$} \\
\hline
\end{tabular}




\begin{abstract}
grupo, que passa, então, a utilizar-se de manobras diversivas, como por exemplo não conseguir decidir-se pelo tema de pesquisa, com o objetivo de não entrar na tarefa.

Era necessário ajudar ao aluno $L$ a ver a realidade do grupo de modo a retomar a dinâmica desejável, para que ao final realizassem efetivamente a tarefa.

0 "insight" foi o experimento de condutividade térmica.

Quando o aluno $L$, e até mesmo os demais componentes do grupo, puderam compreender as conseqüências dessa sua conduta, foi possivel a retomada dos trabalhos e o retorno ao desenvolvimento grupal desejado.
\end{abstract}

Em poucas sessões o grupo conseguiu restabelecer uma dinâmica de papéis bastante positiva, bom nivel de comunicação, de forma que logo passaram a elaborar e tentar concluir a tarefa proposta, o que pode ser interpretado como pertinência.

Após outras duas sessões (especialmente no momento de apresentação da prévia) é perfeitamente possivel identificar um verdadeiro salto de qualidade no grupo, principalmente em termos de identidade, o grupo já não apresenta ansiedades, enfrenta e assume suas dificuldades. Podemos admitir que atingiram a aprendizagem.

Como podemos observar, o desenvolvimento deste grupo fica quase que perfeitamente marcado pela sucessão de etapas que nos permitem enquadrá-lo como grupo operativo.

\title{
5.5. CASO 4
}

\subsubsection{O grupo}

Este grupo foi composto por 3 alunos, da $2^{\mathrm{a}}$ série do Ensino Médio da Escola 1.

Havia dois alunos de sexo feminino $(\mathrm{M} \mathrm{e} \mathrm{N})$ e um aluno de sexo masculino $(\mathrm{O})$. $\mathrm{M}$ e $\mathrm{O}$ eram de etnia afro-brasileira, e $\mathrm{N}$ caucasiana.

$\mathrm{M}$ aparentava ter, por volta, de 28 anos, $\mathrm{N}$ e $\mathrm{O}$ aproximadamente 18 anos.

\subsubsection{O desenvolvimento do processo grupal}

Dando início à estratégia adotada para as aulas da Escola 1, na primeira sessão, além de nossa apresentação (do Prof. Dr. Marcelo Alves Barros e minha), da apresentação das propostas do curso (conforme CAPITULO 3), apresentamos e discutimos as condutas que deveriam ser evitadas pelos yrupos (o contrato pedagógico), e, além disso, tratamos de 
estimular todos os grupos para que sentissem que era realmente possível concluir a tarefa com sucesso.

Em seguida, propusemos o experimento imaginário em que o pesquisador mergulha uma de suas mãos num recipiente contendo água fervendo, mergulha a outra mão num recipiente contendo gelo e em seguida tira as mãos desses recipientes e as mergulha simultaneamente num terceiro recipiente contendo água morna. Pergunta-se, então, qual a sensação que esse pesquisador vai ter da água morna? Como já descrito anteriormente (inclusive no Caso 2), a função desta atividade é dar o "start" ao pensar e à ação.

Depois, entregamos a cada grupo uma lista de questões com o objetivo de balizar o grupo, ou seja, tratava-se de questões conceituais que pretendiam, colocar o aluno diante de situações conflitantes de modo que viesse a questionar seus conceitos espontâneos, estabelecer um fio condutor para o aprendizado, criar condições para discussão em grupo, promover a tomada de funções do sujeito no grupo, estimular a pesquisa individual e em grupo, propor modificações em seus conceitos espontâneos até que finalmente, e idealmente, o grupo chegue ao modelo científico aceito (conforme CAPITULO 3).

Também colocamos à disposição do grupo bibliografia suficiente para que pudessem elaborar sua tarefas.

Concluída a apresentação dessas condições iniciais, ainda na primeira sessão, os grupos deram início ao trabalho de pesquisa para responder às questões da primeira lista.

Durante o tempo restante dessa primeira sessão, os componentes do grupo a que nos referimos neste CASO 4, sem exceção, adotaram uma conduta de distanciamento, tanto de mim, como professor/coordenador, quanto dos demais componentes do grupo.

\begin{tabular}{|c|c|c|c|c|c|}
\hline \multicolumn{6}{|c|}{ QUADRO DE ANÁLISE EVOLUTIVA } \\
\hline \multicolumn{6}{|c|}{ QUANTO AO PROCESSO GRUPAL } \\
\hline $\begin{array}{c}\text { Afiliação } \\
\text { ou } \\
\text { Identificação } \\
\end{array}$ & Pertença & Cooperação & Pertinência & Aprendizagem & Telê \\
\hline \multicolumn{6}{|c|}{ QUANTO À TAREFA } \\
\hline \multicolumn{2}{|c|}{ Pré tarefa } & \multicolumn{2}{|c|}{ Tarefa } & \multicolumn{2}{|c|}{ Projeto } \\
\hline & & & & & \\
\hline
\end{tabular}




\section{Comentários}

Essa conduta, se manifestou em, práticamente, todos os grupos da Escola 1, mesmo que de formas, ou intensidades, diferentes. Alguns individuos liam e reliam seus textos bibliográficos, sem manifestar nenhuma expressão quer de satisfação, insatisfação, dúvidas, nada! Outros fecharam-se completamente na leitura, que era como se estivessem num mundo à parte. Ninguém fazia perguntas. Quando eu interferia, os alunos, polidamente, me diziam que não tinham dívidas...

Na verdade, nesta primeira sessão, estabeleceu-se um clima de ansiedade provocado pelo medo da mudança.

Encerrada a sessão o grupo não manifestou nenhum padrão de comportamento grupal tipico.

Na segunda sessão (uma semana depois) os alunos retornaram à aula e reiniciaram, normalmente, o trabalho de pesquisa com o objetivo de responder às questões propostas. De início, ainda houve uma "resistência" ao estabelecimento e vias de contato explícito...

Professor (para todo o grupo): - Tudo bem, pessoal! Já discutiram algum assunto em que tenha ficado alguma dúvida?

Silêncio constrangedor! Ninguém respondeu nada!

Professor (insistindo com todo o grupo): - Oi, pessoal! Não tiveram tempo ainda de ler nenhum assunto?

Aluno M (para o professor, com timidez): - Sabe professor, a gente não tá muito acostumado a estudar assim!

Professor (para o Aluno M): - Assim como?

Aluno M (para o professor): - Sabe, lendo num monte de livros que o senhor tá dando prá gente!

Aluno $O$ (para o professor): - É $\dot{E}$ muita coisa! A gente não sabe nem como começar!

Professor (para o grupo): - Vamos fazer o seguinte! Eu vou escolher um livro diferente prá cada um de vocês! E vou abrir o livro no mesmo assunto para cada um de vocês também! Querem ver... O que é energia térmica? Ai vou marcar dez minutos para cada um ler o assunto em seu livro. Quando todo mundo tiver lido, vocês me chamam e eu 
ajudo nesta primeira discussão, tá bom? Vocês vão ver como é legal aprender assim!

Após essa minha interferência o grupo evoluiu dentro do esperado. Todos leram seus textos, e terminados os dez minutos, eles mesmos me chamaram para iniciar a discussão...

Eu só precisei dar o pontapé inicial na discussão...

Professor (para o grupo): - Muito bem! Quem pode me dar uma explicação do que é energia térmica, mas tem que ser com suas próprias palavras!

Aluno M (para o professor, agora com menos timidez): - Eu posso falar o que eu acho?

Professor (para o grupo): - Então turma! Ele pode começar?

Os demais componentes do grupo (quase que em uníssono): - É lógico que pode!

Professor (para o grupo): - Otimo! Só que depois, M vai querer ouvir o que vocês acharam do que ele entendeu! Combinado?

Os demais componentes do grupo: - Certo! Tudo bem!

Professor (para o aluno $\mathrm{M}$ ): - $M$, você pode começar?

Aluno M (para o grupo): - Eu entendi o seguinte...

\section{Comentários}

A conduta do aluno $M$, apresentando o que havia compreendido sobre o conceito de energia térmica, por alguns minutos (sem ser interrompido), certamente foi um bom começo para o desenvolvimento grupal. No entanto minha expectativa era de que se estabelecesse um inicio de comunicação mais efetivo entre os componentes do grupo. Eu esperava pelo estabelecimento de um processo de discussão entre os membros do grupo, que nesse momento não ocorreu.

Ao final da apresentação do aluno M...

Professor (para o aluno $\mathrm{M}$, e demais componentes):-Muito bom M! E vocês, gente não têm nada prá dizer sobre energia térmica?

Aluno $O$ (para o professor): - Eu concordo com $M$ !

Aluno N (para o professor): - Eu também acho que está ótimo! 
Professor (para os alunos $\mathrm{N}$ e 0):-Realmente, está bom, mas nos livros que vocês leram não teve nenhuma idéia interessante também?

Alunos N e $\mathbf{O}$ (para o professor): - Eu acho que não!

\section{Comentários}

Tentando não demonstrar ansiedade ou decepção, continuei tentando manter a comunicação...

Professor (para os grupo): - Já foi um grande passo para o aprendizado. Agora eu só vou dizer o assunto: temperatura... Vocês vão procurar onde esse assunto está no livro, vão ler como antes, e em dez minutos a gente recomeça discussão. Fechado?

O grupo: - Tudo bem!

\section{Comentários}

Essas minhas duas solicitações ao grupo, em conjunto, parecem ter contribuido de forma significativa para a abertura da comunicação franca...

Por um lado o "sucesso" de M, mostrava que seria possivel realizar o que eu pedia. Por outro lado, localizar o assunto escolhido em seus livros representava certa dificuldade... Então para superar essa dificuldade, começaram a solicitar a colaboração, uns dos outros. Foi o princípio da comunicação grupal.

No período que eu determinara para a pesquisa sobre o conceito de temperatura, pude observar que os componentes do grupo começavam a interagir entre si: trocavam idéias, colaboravam com a leitura do texto do outro, concordavam quanto a alguns pontos, discordavam quanto a outros.

Ao final dos dez minutos fui chamado pelo grupo...

Aluno N (para o professor): - Professor, a gente já leu e quer discutir com o senhor!

Professor (para os grupo): - Muito bom! Pude ver vocês discutindo, estava muito boa a discussão! Vamos lá! Quem quer começar?

\section{Comentários}

Para minha surpresa todos, sem constrangimento aparente, se propuseram a começar a expor suas idéias... 
Professor (para o aluno 0, em tom de brincadeira): - Está bem 0 , já que você está insistindo tanto, seus colegas vão deixar você falar primeiro!

Aluno $\mathbf{O}$ (para o grupo): - Eu acho que...

\section{Comentários}

$O$ aluno $O$, expôs o que havia aprendido sobre temperatura, de forma absolutamente compativel com seu vocabulário e padrão de conhecimento. Apesar de demonstrar durante sua comunicação, tanto verbal como gestual, algum desconforto, como seria mesmo de se esperar, sua conduta me fez acreditar que o grupo começava a mostrar, efetivamente, grandes possibilidades de mobilizar-se no sentido de entrar na tarefa.

Ao final da apresentação do aluno 0 ...

Professor (para o grupo): - Muito bem O! Agora é a vez de Nfalar! No que você pode ajudar a gente $N$ ? $E$ você $M$ ?

Desta vez o aluno $\mathrm{N}$ também mostrou seu ponto de vista, assim como o aluno $\mathrm{M}$. Ambos apresentaram outras situações, relativas ao conceito de temperatura, que haviam lido em seus livros e que acharam importante comentar.

Essa "troca" de informações entre os elementos do grupo, e praticamente sem a minha participação, estabeleceu uma discussão bastante produtiva, tanto do ponto de vista de aprendizado de conceitos físicos quanto para o desenvolvimento grupal.

Propositalmente, aproveitando que um outro grupo havia me solicitado, me afastei do grupo dizendo que continuassem a discussão sem mim, e que se fosse necessário, me chamassem novamente.

Ainda assim, a discussão continuou, até o final daquela sessão, com a participação ativa de todos os componentes, ouvindo, falando, lendo, organizando idéias, tentando esclarecê-las, enfim, o grupo estava em mobilização.

\begin{tabular}{|c|c|c|c|c|c|}
\hline \multicolumn{7}{|c|}{ QUADRO DE ANALISE EVOLUTIVA } \\
\hline \multicolumn{6}{|c|}{ QUANTO AO PROCESSO GRUPAL } \\
\hline $\begin{array}{c}\text { Afiliação } \\
\text { ou } \\
\text { Identificação }\end{array}$ & Pertença & Cooperação & Pertinência & Aprendizagem & Telê \\
\hline & $X$ & & & & \\
\hline
\end{tabular}




\begin{tabular}{|l|c|c|}
\hline \multicolumn{1}{|c|}{ QUANTO À TAREFA } \\
\hline \multicolumn{1}{|c|}{ Pré tarefa } & \multicolumn{1}{|c|}{ Tarefa } & \multicolumn{1}{c|}{ Projeto } \\
\hline \multicolumn{1}{|c|}{ X } & \multicolumn{1}{|c|}{} \\
\hline $\begin{array}{l}\text { Comentários } \\
\text { A partir desse momento, foi possível identificar o estabelecimento de certo nivel de confiança, } \\
\text { rotatividade de papéis. }\end{array}$ & \\
\hline
\end{tabular}

$\mathrm{Na}$ terceira sessão (na semana seguinte) tivemos um problema - greve nos transportes coletivos - e o aluno $\mathrm{M}$, que embora de forma não muito definida, ainda assim assumia o papel de iniciador contribuinte, não compareceu à sessão.

\section{Comentários}

Esse fato provocou uma forte descontinuidade no desenvolvimento grupal: os alunos $N$ e $O$, mostraram-se mais distantes, menos propensos e dispostos à discussão.

Foi possivel perceber que, de forma geral, o grupo regrediu, isto é, a ausência do aluno $M$, talvez devido ao papel que ele vinha assumindo, ou talvez devido à sua ausência, propriamente dita, que explicitou a possibilidade de dissolução do grupo, fez com que o vinculo entre os componentes presentes se enfraquecesse, aumentando seu distanciamento.

$\mathrm{Na}$ quarta sessão (uma semana depois), para o alívio de todos, tivemos a presença de todos os componentes desse grupo.

De início foram necessárias alguns estímulos para "quebrar o gelo", mas após algumas interferências minhas, eles reativaram, efetivamente, o processo de desenvolvimento grupal.

\section{Comentários}

A comunicação com esses alunos me fez perceber que eles, realmente, encontravam dificuldade no processo de pesquisa. Por isso, durante aquela, e a sessão seguinte, apliquei a rotina de indicar-lhes o item a ser pesquisado, estabelecer o tempo de pesquisa e "dirigir" a discussão.

Esse procedimento mostrou-se eficiente para o grupo, tanto que ao final da quinta sessão, os componentes do grupo já se propunham (por iniciativa própria) a responder as questões que 
lhes haviam sido propostas.

Nesse momento, conversei com o grupo, com o objetivo de mostrar-lhes que estavam plenamente capacitados a realizar, por si próprios, qualquer pesquisa, e que seria muito mais eficiente para eles que voltassem ao esquema proposto inicialmente.

Os alunos compreenderam a proposta e resolveram aceitá-la.

$\mathrm{Na}$ sexta sessão (na semana seguinte), o grupo, com pequenas interferências de minha parte, assumiu um regime de trabalho bastante positivo.

A partir da lista de questões, determinavam, e dividiam entre si, os temas centrais. Cada componente fazia uma pesquisa "inicial" sobre seu tema (o componente localizava o tema em dois ou três livros), em seguida cada componente lia um dos livros, depois discutiam sobre esse conteúdo e finalmente se propunham a responder às questões. É importante ressaltar que com raras exceções, somente fui solicitado quando houve dúvidas sociabilizadas.

Independentemente da estratégia adotada pelo grupo, esta conduta explicita a operatividade do grupo, sua tentativa de elaborar e concluir a tarefa proposta, a comunicação entre os componentes do grupo, além da mudança qualitativa do grupo, que fica comprovada pela tomada de posição ativa em relação à tarefa proposta

\begin{tabular}{|c|c|c|c|c|c|}
\hline \multicolumn{6}{|c|}{ QUADRO DE ANÁLISE EVOLUTIVA } \\
\hline \multicolumn{6}{|c|}{ QUANTO AO PROCESSO GRUPAL } \\
\hline \multirow[t]{2}{*}{$\begin{array}{c}\text { Afiliação } \\
\text { ou } \\
\text { Identificação } \\
\end{array}$} & Pertença & Cooperação & Pertinência & Aprendizagem & Telê \\
\hline & & & & $\boldsymbol{X}$ & \\
\hline \multicolumn{6}{|c|}{ QUANTO À TAREFA } \\
\hline \multirow{2}{*}{\multicolumn{2}{|c|}{ Pré tarefa }} & & $f a$ & \multicolumn{2}{|c|}{ Projeto } \\
\hline & & \multicolumn{2}{|c|}{$X$} & & \\
\hline \multicolumn{6}{|l|}{ Comentários } \\
\hline \multicolumn{6}{|c|}{ Decidi apresentar este caso devido à regularidade apresentada em seu desenvolvimento. Isto } \\
\hline \multicolumn{6}{|c|}{ é, entre todos os casos que pude acompanhar, poucos mostram como este caso (e o CASO 5), } \\
\hline \multicolumn{6}{|c|}{ uma sucessão de momentos tão compativel com o modelo de grupos operativos proposto por } \\
\hline \multicolumn{6}{|c|}{ Pichon-Rivière. } \\
\hline
\end{tabular}


Podemos observar (na segunda sessão) o momento da identificação com o grupo. Logo a seguir uma integração mais intensa, então o grupo passa pela pertença. Depois observamos uma determinada dinâmica de papéis, com $M$ assumindo uma certa liderança, é o momento da cooperação.

Logo após minha interferência, no sentido da capacitá-los a realizar pesquisas, o grupo passa a comunicar-se mais e melhor, tanto em termos de forma como de conteúdo, e além disso passa a sentir que pode elaborar e concluir a tarefa proposta, ou seja, o grupo atingiu o momento da pertinência. Essa momento de pertinência vem associado ao momento da aprendizagem, visto a mudança qualitativa do grupo e sua tomada de posição ativa em relação à realização da tarefa.

\subsection{CASO 5}

\subsubsection{O grupo}

Neste caso o grupo estudado foi composto por 4 alunos, da $2^{\mathrm{a}}$ série do Ensino Médio da Escola 2.

Havia três alunos de sexo feminino ( $P, Q$ e $R)$ e um aluno de sexo masculino (T). A idade média era por volta de 16 anos, e à primeira vista, não apresentavam nenhum indício de que se tratasse de indivíduos com características pessoais fora do esperado.

\subsubsection{O desenvolvimento do processo grupal}

Como descrito no CAPITULO 3, na primeira sessão fiz a apresentação das propostas do curso, apresentei e, em seguida, discutimos as condutas que deveriam ser evitadas pelos grupos e sugeri alguns temas de pesquisa. Tentei mostrar-lhes que havia muitos outros temas possiveis e interessantes, e que a escolha do tema de pesquisa era da exclusiva responsabilidade deles. Forneci bibliografia inicial para pesquisa, e procurei estimular a todos os grupos para que sentissem que era realmente possível concluir a tarefa com sucesso.

A seguir, todos os grupos, iniciaram a leitura de seus textos com o objetivo de selecionar seu tema de pesquisa.

Como esse grupo ocorreu já no último período de observação, minha experiência adquirida pela análise dos grupos anteriores me levou desde essa sessão inicial, a observar 
atentamente todos os grupos, na tentativa de identificar condutas específicas desse momento, que viessem a fornecer subsidios para auxiliar a compreensão do desenvolvimento grupal.

Logo de princípio, o grupo analisado neste caso chamou muito minha atenção: mesmo não sendo muito próximos, apesar de colegas de classe, o grupo mostrou uma integração surpreendente. Quase que imediatamente (em questão de menos de meia hora) já mostravam certa nivel de organização, que eu não havia observado em nenhum outro grupo. Ao contrário da maioria dos outros grupos, que no momento inicial do desenvolvimento grupal partiam obstinadamente para a leitura de textos na "busca de um tema de pesquisa", os componentes deste grupo procuraram estabelecer, antes disso, uma metodologia com o propósito de identificar, coletivamente, temas que inicialmente apresentassem aspectos de interesse para cada componente do grupo...

Aluno R (para os demais colegas do grupo): - Olha turma, eu acho o seguinte: como a gente não se conhece direito, e vamos trabalhar em grupo, eu acho que a gente primeiro tem que escolher os temas que cada um achar legal. Depois faz uma lista e mostra pros outros. Ai agente vota e escolhe o melhor. Que vocês acham?

Aluno T (para os demais colegas do grupo, em resposta): - Bom, prá começar a idéia é legal. Só que eu acho que não adianta muito fazer só uma lista dos temas e mostrar pros outros. Assim não adianta muito. Tem que mostrar o que viu de legal no tema prá gente poder entender! Só a lista com o nome do tema não dá, né? Tem que explicar porque é legal!

Aluno P (para os demais colegas do grupo): - Eu acho melhor assim!

Aluno R (para os demais colegas do grupo, retomando a palavra): - Eu também! Fu concordo!

Aluno $\mathbf{Q}$ (para os demais colegas do grupo): - Eu também acho melhor assim. Mas eu acho também que seria legal, conforme a gente vai lendo, a gente ir marcando em que livro leu, que página, assim se tiver dúvida é só voltar, e não perde tempo.

Aluno T (para os demais colegas do grupo, em resposta): - Boa idéia. Assim não perde tempo! Vamos perguntar pro professor que ele acha!

Apesar de estar acompanhando, bem próximo, a conversa desses alunos, esperei ser solicitado, antes de interferir. 
Fui informado, pela orientação, que esses alunos, desde o Ensino Básico, eram considerados alunos "muito bons", com excelentes notas, participativos, disciplinados, sem qualquer restrição, ou seja, apresentavam alto rendimento escolar.

$\mathrm{Na}$ segunda sessão (duas semanas depois) os alunos retornaram à aula e reiniciaram, seu trabalho de pesquisa.

Pude verificar que naqueles quinze dias, esses alunos haviam levantado uma enorme lista de assuntos, inclusive dois deles haviam trazido bibliografia própria (que incluía alguns livros, revistas, cópias xerox, etc.).

No início, sem perceber o que isso representaria em termos de tempo, eles tentaram discutir todos os temas selecionados.

Aluno R (para os demais colegas do grupo): - Vamos começar a apresentação dos assuntos! Quem começa?

Aluno Q (respondendo, rapidamente): - Olha eu posso começar. Mas são muitos temas! Tem problema?

Aluno P (para os demais colegas do grupo): - Eu também tenho muitos temas. Acho melhor cada um falar um tema de cada vez, ai passa pro seguinte.

Aluno T (para os demais colegas do grupo): - Eu acho melhor assim!

Começou então o rodízio de apresentação de assuntos que cada qual considerava, para si, interessante.

No entanto a segunda sessão terminou e eles não haviam discutido todos os assuntos selecionados individualmente.

\begin{tabular}{|c|c|c|c|c|c|}
\hline \multicolumn{7}{|c|}{ QUADRO DE ANALISE EVOLUTIVA } \\
\hline $\begin{array}{c}\text { QUANTO AO PROCESSO GRUPAL } \\
\text { Identificação }\end{array}$ & Pertença & Cooperação & Pertinência & Aprendizagem & Telê \\
\hline & & $X$ & & & \\
\hline \multicolumn{7}{|c|}{ QUANTO À TAREFA } & & Projeto \\
\hline Pré tarefa & \multicolumn{3}{|c|}{ Tarefa } & & \\
\hline
\end{tabular}




\section{Comentários}

Como esse grupo passara a me interessar de forma especial, decidi acompanhar seu desenvolvimento com mais atenção.

É importante dizer que já desde o inicio do processo todos os componentes do grupo se mostraram propensos ao trabalho em grupo, sem qualquer tipo de restrição, e demonstrando, inclusive, equilibrio e facilidade em se comunicar.

Pude perceber, por exemplo, que durante o rodizio de apresentação dos assuntos selecionados, não se limitavam a relacionar e expor aquele assunto. Eles iam mais além. Eles tentavam mostrar e convencer aos demais porque consideravam aquele assunto interessante, e em vários casos apontavam até mesmo facilidades já conseguidas quanto às referências bibliográficas.

Durante o processo de exposição dos temas pré selecionados, muito embora fosse perceptivel o desejo de cada um dos componentes de que fosse o seu, o tema escolhido pelo grupo, não fui capaz de identificar nenhuma conduta estereotipada nesse sentido..

Após duas semanas, na terceira sessão, os alunos retornaram à aula e continuaram com o processo de seleção do tema.

Os componentes se mostravam totalmente envolvidos nessa dinâmica, contribuindo, propondo sugestões, discutindo questões, rejeitando temas, sempre de forma democrática, e sem evidenciar como já foi dito nenhuma conduta estereotipada.

A terceira sessão terminou sem que tivessem selecionado o tema.

\section{Comentários}

Nesta sessão fui chamado a intervir por uma única vez.

Apesar disso continuei observando atentamente a conduta do grupo, e pude perceber que começava a se estabelecer um certo clima de ansiedade, talvez provocado pela indefinição quanto ao tema de pesquisa.

Por isso mesmo terminada a sessão e tentando ser o menos alarmante possivel perguntei aos componentes do grupo quantos temas faltava discutir. A resposta foi 17 temas.

Caso minha suspeita quanto a ansiedade do grupo estivesse certa, essa quantidade de temas propostos poderia se transformar num problema, já que naquela sessão eles somente haviam 
discutido 6 temas.

Resolvi que na sessão seguinte eu iria intervir no sentido de tentar esclarecer essa potencial dificuldade.

$\mathrm{Na}$ quarta sessão, os alunos retornaram e reiniciaram suas atividades, sem demonstrar nenhuma alteração significativa em sua conduta.

Ainda assim, eu estava decidido a que se detectasse algum aumento de ansiedade no grupo, causada pela não seleção do tema de pesquisa, eu interferiria no sentido de ajudar o grupo a superar essa dificuldade.

Ao final daquela sessão, como já era esperado, a demora na seleção do tema começou a provocar o desânimo no grupo. Como conseqüência teve início uma série de disputas provocadas pela formação de subgrupos, internos ao grupo, além de conflitos típicos do choque entre a verticalidade de sujeitos e a horizontalidade do grupo. Enfim os interesses individuais ou de pequenos grupos tentavam se sobrepor aos interesses gerais do grupo. Essa dinâmica, se não elaborada adequadamente, poderia estagnar o grupo.

Apenas aguardei pela oportunidade de ser chamado a interferir no grupo.

Mas, para aguçar minha ansiedade, naquela sessão, não tive a oportunidade de intervir no grupo. E a sessão terminou com o grupo mergulhado nesse processo de estagnação.

\section{Comentários}

Minhas experiências anteriores haviam me convencido de que o papel fundamental do coordenador de grupos é o de levar o grupo a se deparar com a realidade dos problemas que o cercam, e de ajudá-los a encontrar caminhos para superar essas dificuldades, de forma a evitar que o grupo entre num processo de estagnação estereotipada.

Por isso, agora eu estava firmemente decidido a intervir no grupo de forma a ajudá-los a entrar na tarefa.

$\mathrm{Na}$ quinta sessão, novamente os alunos retornaram e reiniciaram suas atividades.

Desta vez era possível sentir o clima de insatisfação que pairava sobre o grupo. 0 interessante era que ninguém falava nada, ou assumia explicitamente nenhuma atitude, mas a comunicação gestual não deixava dúvidas quanto à potencial entrada do grupo no processo de estagnação estereotipada. 
Mesmo sem ser solicitado, aproveitei a oportunidade de cumprimentá-los de forma mais próxima, e comecei a conversar com eles...

Professor (para o grupo): - E então gente, vocês estão trabalhando em qual tema? Faz tempo que a gente não conversa!

Aluno Q (para o professor): - Pô! Professor isso aqui tá muito mal!

Professor (tentando mostrar-me desapreensivo, para o grupo): - Como assim? Não entendi!

Aluno $\mathbf{Q}$ (para o professor): - O trabalho, parece que não rende!

Professor (ainda tentando mostrar-me desapreensivo, para o grupo):-Mas às vezes o começo é duro mesmo! Não é fácil ter uma boa idéia. Às vezes gente muito competente encontra a maior dificuldade para realizar um trabalho legal. E tem mais! Quanto mais competente o individuo é mais crítico ele costuma ser, então fica mais dificil aceitar um tema.

Aluno P (para o professor): - É. Mas é que aqui o jogo tá duro demais! Não sai nada!

Professor (para o grupo): - Puxa pessoal quando eu perguntei a vocês quantos temas vocês selecionaram, vocês me disseram que eram quase vinte! Então como é que não sai nada?

Aluno R (para o professor): - É. Mas é por isso mesmo, a gente discute, discute, discute, e não chega a lugar nenhum!

Aluno P (para o professor): - É isso mesmo.

Professor (para o grupo): - Será que cada um de vocês não selecionou temas demais? Será que essa escolha não acabou por transferir para seus colegas de grupo sua própria indecisão quanto ao tema. Pensem bem nisso! Eu vou dizer uma coisa para vocês. Essa atitude de apresentar os temas de cada um para o grupo, e depois decidir pelo melhor tema, eu achei demais. Mas será que essa grande quantidade de temas não é resultado de falta de algum critério inicial? Pensem bem nisso. Depois, quando tiverem chegado a uma conclusão em grupo, me chamem.

Eu deixei o grupo, e pude observar que começavam a conversar sobre o problema. Em poucos instantes (talvez dez minutos) fui chamado pelo grupo. 
Professor (para o grupo): - Vocês já resolveram alguma coisa?!

Aluno T (para o professor): - Bom, a gente conversou, e todos concordamos que a gente quis forçar a barra demais!

Professor (para o aluno $\mathrm{T}$ ): - $O$ que vocês querem dizer com forçar a barra?

Aluno T (para o professor): - $\dot{E}$, a gente escolheu temas demais, porque, pelo menos eu, queria que meu tema fosse escolhido. Ai se eu escolhesse muitos temas aumentava minha chance!

Aluno R (para o professor): - Eu também pensei mais ou menos assim!

Professor (para o grupo): - Sabem de uma coisa? Perceber isso é muito bom prá vocês. A gente não pode nunca esquecer que o interesse maior é o sucesso do grupo. $\dot{E}$ através dele que vamos crescer como individuos! A gente deve deixar prá lá essa coisa do eu, eu só eu... e trabalhar prá que todos evoluam. Isso que vocês perceberam foi muito bom para o grupo. E agora, que vamos fazer? Também não adianta apenas reconhecer a dificuldade temos que ter pulso firme e resolver o problema!

Aluno P (para o professor): - Isso é que a gente não tá conseguindo resolver!

Professor (para o grupo): - Todos vocês estão com essa dificuldade? Já conversaram sobre isso? Têm certeza que não resolvem o problema sozinhos?

Aluno $\mathbf{Q}$ (para o professor): - Bom a gente acabou de falar sobre isso e ninguém sabe como sair desse problema! Acho que a gente meio que se viciou nisso de mostra, discute, e não consegue sair disso!

Professor (para o grupo): - Bom, eu acho que o mais importante vocês já fizeram, que é entender o problema e que precisam vencer essa dificuldade. Resolver o problema, é questão de pensar um pouco, amadurecer as idéias, que logo a solução vem! Tenho a impressão que vocês conseguem isso! Vocês não querem tentar?

Aluno $\mathbf{Q}$ (para o professor e para os demais colegas): - Eu acho que a gente deve tentar!

Os demais colegas também concordaram.

Deixei o grupo discutindo sobre o problema que encontravam, mas, aquela sessão terminou, sem que tivessem conseguido resolver aquela dificuldade básica. 


\section{Comentários}

Eu deixei o grupo trabalhando, mas fiquei bastante atento, pois pude perceber que estavam bastante fragilizados.

Muito embora, tivessem compreendido qual sua real dificuldade - agora eles estavam conscientes de que, efetivamente, não haviam se proposto a analisar cada assunto e escolher $o$ "melhor", na verdade, o que cada um desejava era escolher um de seus próprios temas devido ao desgaste psicológico dos componentes do grupo, eu tinha a sensação de que muito dificilmente eles conseguiriam elaborar essa situação.

Por isso resolvi que se percebesse uma outra manifestação no sentido da estagnação do grupo, eu iria interferir para ajudá-los a encontrar o caminho da entrada na tarefa.

$\mathrm{Na}$ sexta sessão, os alunos retornaram e novamente reiniciaram a tentativa de resolver sua dificuldade de estabelecer um critério para a escolha do tema de pesquisa.

Passado algum tempo (talvez trinta minutos) me convenci, devido à movimentação dos componentes do grupo, que se mostravam nervosos, irriquietos, e pela tendência, novamente, à formação de subgrupos, de que era necessário intervir para evitar uma nova estagnação do grupo.

Professor (para o grupo): - Tudo bem, gente? Como vão as coisas? Já se decidiram pelo tema?

Aluno T (para o professor): - Ainda não. E está complicado!

Professor (para o grupo): - Como assim complicado?

Aluno T (para o professor): - Por mais que a gente faça, não consegue sair do lugar!

Aluno $\mathbf{Q}$ (para o professor e para os demais colegas): - $\dot{E}$ coisa demais, a gente conversa muito sobre cada tema, dai não anda!

Professor (para o grupo): - Mas se o problema é só tempo, vocês podem resolver até mesmo fora da aula!

Aluno $\mathbf{Q}$ (para o professor e para os demais colegas): - Mas não é só isso, a gente tá cansado de conversar e não andar prá frente! 


\section{Comentários}

Percebi que havia se estabelecido um estado de desgaste, acentuado, do processo. Conclui que se insistisse, simplesmente, na continuidade daquela dinâmica de tentativa de discussão entre componentes do grupo, o grupo terminaria por extinguir-se.

Para evitar esse final decidi sugerir uma mudança de estratégia...

Professor (para o grupo): - Mas então a solução é fácil! Como a esta altura cada um de vocês já conhece um pouco da forma de pensar dos demais, porque cada um de vocês não escolhe, dentro de sua própria lista de assuntos, um único assunto, no máximo dois? É só cada um, usando a experiência que adquiriu durante esse tempo de discussão, $e$ se conscientizando da responsabilidade de representar o grupo como um todo, fazer a escolha mais adequada. Dai, depois, e só escolher entre quatro assuntos. Fica super fácil.

\section{Comentários}

Pude perceber um grande alivio estampado no rosto de todos.

Aquela dinâmica que havia se estabelecido anteriormente, de superar o conflito da escolha entre seus próprios temas e o dos colegas, se tornara um fardo muito pesado. $O$ grupo, não havia conseguido superar, efetivamente, aquele momento, e isso colocava o grupo muito próximo da ruptura.

Aluno Q (para o professor e para os demais colegas): - Pô, mas essa idéia é ótima! Vai melhorar muito prá gente! A gente não agüentava mais aquele rolo todo.

Os demais alunos também mostraram grande satisfação com aquela sugestão.

Em seguida, teve início uma dinâmica de operatividade completamente renovada.

Cada um dos componentes do grupo, ainda naquela sessão, selecionou o assunto que considerou mais representativo.

\section{Comentários}

Considero relevante relatar que durante esse processo de seleção, pude observar que por diversas vezes, os componentes do grupo solicitavam a opinião, uns dos outros, trocavam idéias, enfim decidiram juntos, quais seriam os temas mais adequados que deveriam ser escolhidos.

Aquela sessão terminou dentro de um clima, ao contrário das três anteriores, bastante 
positivo.

Para minha surpresa, agradável por sinal, na sessão seguinte (sétima sessão, já estávamos entrando no terceiro bimestre), o grupo retornou à aula já com o tema decidido.

\section{Comentários}

Evidentemente eles haviam se reunido fora das sessões, o que já seria uma conduta bastante positiva. Mas além disso, notei que nenhum dos alunos, mencionou qual dos componentes havia sugerido o tema escolhido pelo grupo. $\dot{E}$ claro que esse fato pode ter passado desapercebido por eles, mas ainda assim, para passar por desapercebido esse fato não deve sido significativo, e isso já é indicador de uma dinâmica grupal bastante positiva.

A partir daí, esses alunos estabeleceram uma operatividade surpreendente que não mais se abalou, até o final do curso.

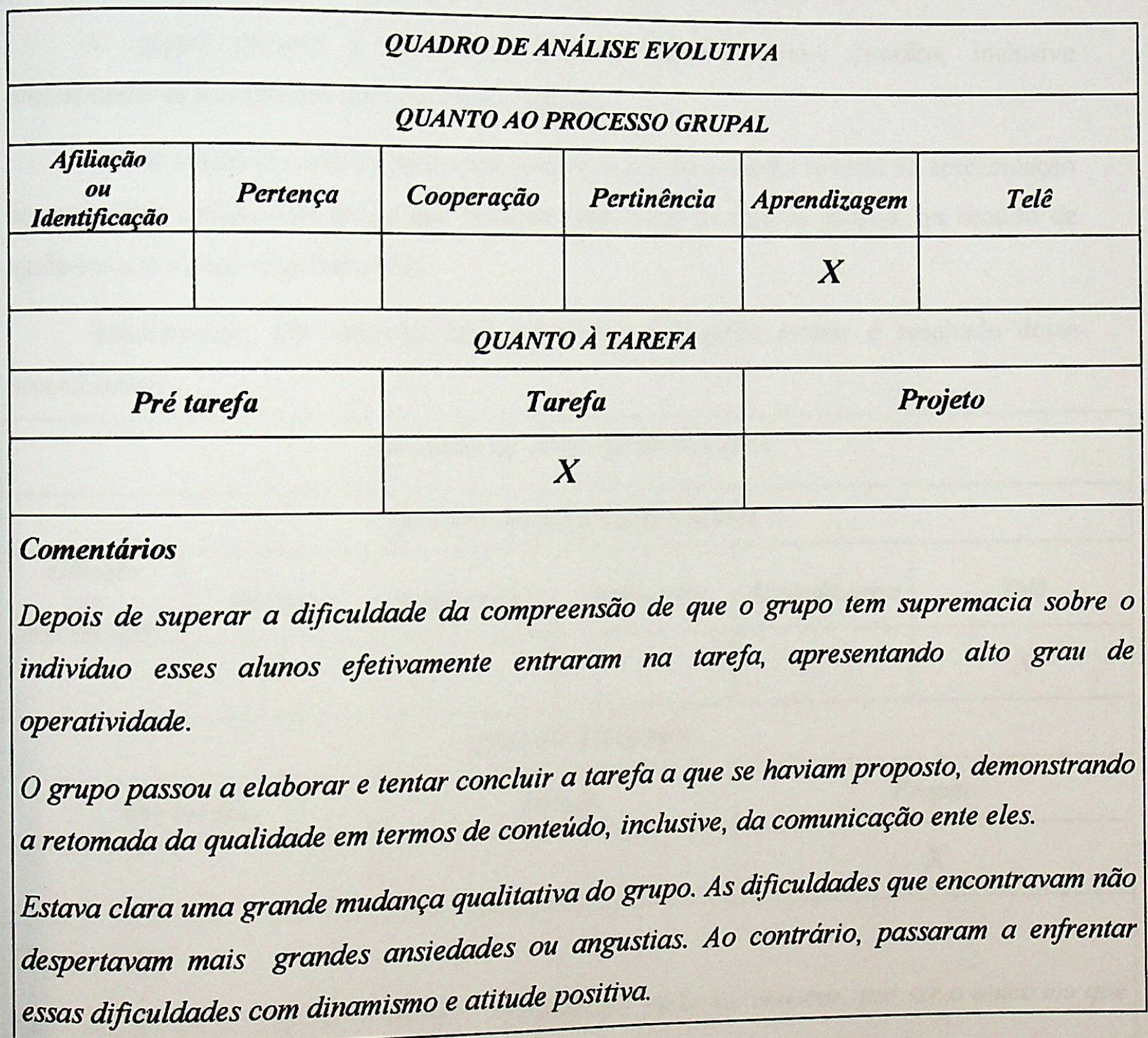


$\mathrm{Na}$ décima sessão o grupo já havia preparado sua apresentação. Eles tinham concluído a tarefa a que se propuseram.

Analisei o trabalho e pude constatar que realmente estava muito bom. Então, para que servisse de estímulo tanto para demais grupos, quanto para eles próprios, solicitei que apresentassem seu trabalho para os demais colegas.

A apresentação foi um sucesso! Não apenas pela apresentação em si, mas pelo retorno que acabou por provocar.

Os demais grupos sentiram que seria possivel realizar um grande trabalho, e o grupo, tema deste caso, se sentiu incentivado a ir mais longe.

Na sessão seguinte, o grupo me solicitou e me propôs a inclusão de novos itens em sua apresentação... tinha início a entrada do grupo no momento do projeto...

O grupo passara a estabelecer para si próprio novos desafios, inclusive predispondo-se a colaborar com os demais grupos.

Como tínhamos apenas mais uma sessão, antes do período normal de apresentação dos trabalhos solicitei ao grupo que colaborassem com os demais grupos, no sentido de ajudá-los a concluir seus trabalhos.

Infelizmente, por absoluta falta de tempo, não pude avaliar o resultado desse procedimento.

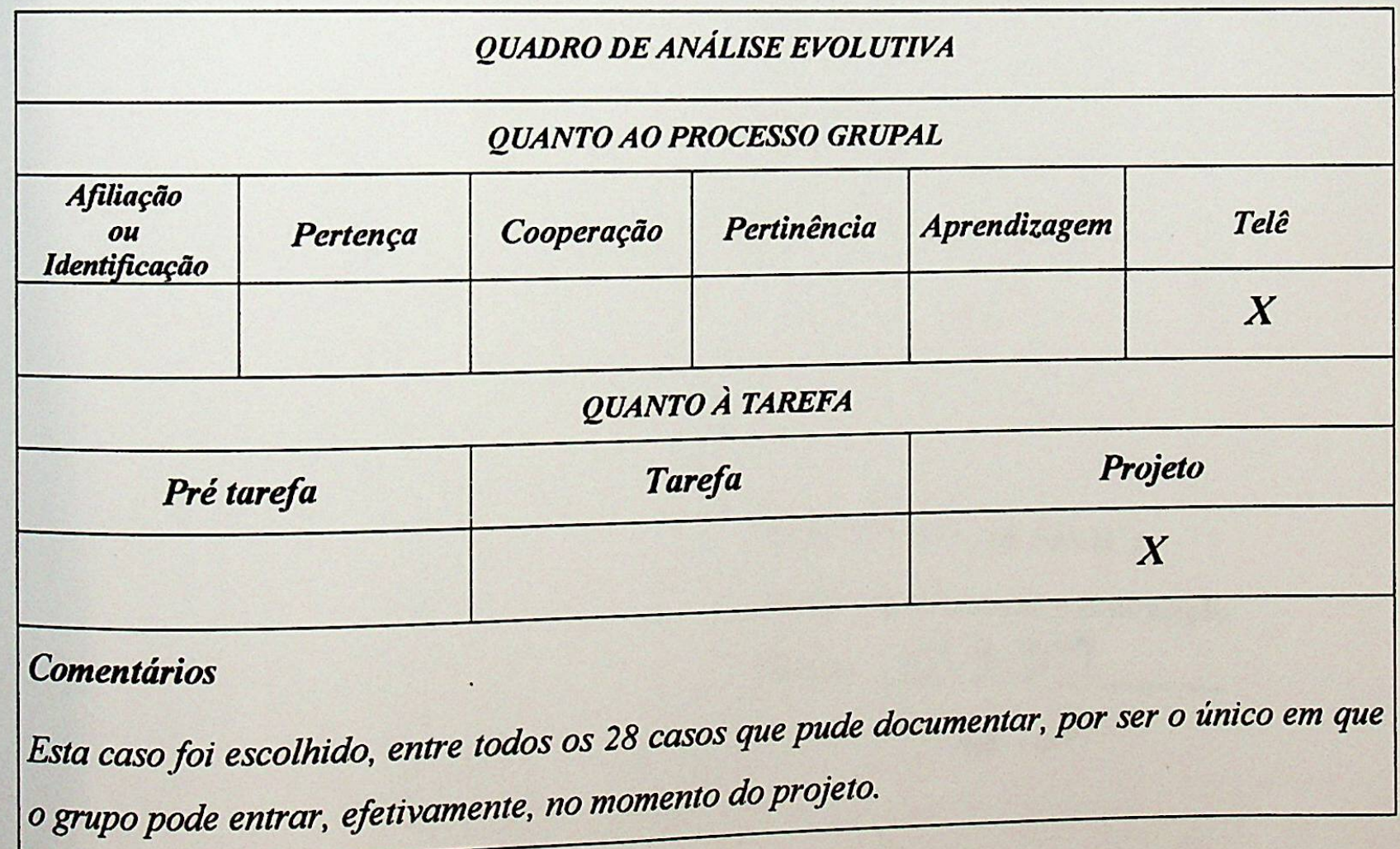


A análise da quase totalidade de casos (houve três casos de extinção de grupos, e outros dois que não concluiram a tarefa), aponta no sentido, ao menos em termos de grupos operativos de aprendizado, é perfeitamente possivel atingir a conclusão da tarefa.

No entanto, quanto à entrada no momento do projeto, somente foi possivel observar em apenas dois casos (o CASO 1, que apresenta alguns indicadores desse momento, e este, $o$ CASO 5 , onde é possivel perceber um clima grupal de trabalhar com o grupo ou com 0 coordenador, colaborando com ele, coordenador, no desenvolvimento dos demais grupos).

\section{INSTITUTO DE FÍSICA}

Serviço de Biblioteca e Informação

Tombo: 3759

ex. 2 
101

6. CONCLUSÕES 


\subsection{INTRODUÇÃO}

A análise dos casos documentados para a presente pesquisa (num total de 28 casos), a exemplo dos 5 casos relatados no CAPÍTULO 5 , exatamente por serem os mais representativos entre os padrões observados, nos leva a estabelecer algumas conclusões significativas, em quatro diferentes aspectos de abordagem.

\subsubsection{Quanto ao desenvolvimento próprio dos grupos operativos de aprendizagem.}

Como é possível observar, a partir dos casos apresentados no capítulo anterior (e que também ocorrem nos outros 23 casos analisados), apesar de condutas gerais já bem conhecidas e previstas pelos modelos de grupos operativos, cada grupo estudado apresentou características e desenvolvimento próprio, demonstrando, de forma clara, portanto, uma determinada individualidade do padrão de operatividade do grupo.

Em minha análise, estou convencido de que esse comportamento seja, na verdade, uma contribuição da individualidade de cada sujeito no grupo, ou seja, mesmo quando o grupo atinge a operatividade, e seus componentes já assimilaram o conceito que leva à supremacia do grupo sobre o indivíduo, ainda assim, a individualidade do sujeito, se mantém viva na genética grupal. Ou seja, o que ocorre no grupo corresponde a um processo resultante das duas tendências básicas do indivíduo: a de se abastecer e a de se modificar para acomodar-se aos novos elementos assimilados (portanto um processo análogo à equilibração, proposta por Piaget), ou ainda, a uma mudança de paradigma, sem que no entanto o sujeito, abandone o conhecimento anterior.

Estas individualidades quando interpostas vão gerar uma amplitude ilimitada de possibilidades de comportamentos grupais.

Muito embora meu trabalho esteja limitado à análise dos aspectos gerais do desenvolvimento grupal, o estudo destes 28 casos me levam a considerar que o desenvolvimento grupal deva ser analisado em dois niveis distintos: no primeiro nível, que poderíamos chamar de macro conduta, devem ser considerados aspectos coletivos do comportamento grupal, passiveis de alguma generalização; já num segundo nível, a micro conduta, deve-se considerar qual a contribuição do sujeito, como indivíduo, no desenvolvimento grupal.

Dentro de nossa proposta, que é a análise da macro conduta, nossos dados deixam perfeitamente claro, por exemplo, que no momento da pré-tarefa, ou início da aquisição de 
informação - que nos grupos operativos de ensino corresponde ao momento inicial da aprendizagem - os grupos, de modo geral, se deparam com volumes de informação maiores do que podem verbalizar ou declarar conscientemente. Essa conflito pode provocar um nivel de ansiedade suficientemente alto, de modo a estimular, uma primeira introjeção da informação, primitiva, então a nível corporal, que pode ser evidenciada por uma dramatização, que pode levar os componentes do grupo à despersonalização, ou até a reações obsessivas e mesmo fóbicas, ou ainda, a uma conduta de fixação ao pensamento que o impede de agir. Esse processo pode explicar de maneira bastante satisfatória a conduta apresentada por todos os grupos estudados, sem exceção. Devemos destacar, no sentido de caracterizar bem esse processo, o CASO 1 - em que o grupo, normalmente bastante tranqüilo e pacífico, não consegue entrar na tarefa, e passa a se manifestar quase que agressivamente contra o professor, evidenciando os processos de despersonalização e obsessividade.

Outro aspecto que caracteriza bem e individualidade dos grupos operativos de aprendizagem está na questão de dispersão e coesão do grupo. Se relembrarmos o desenvolvimento do CASO 2, ainda que ele tenha se extinguido, e dos CASOS 3, 4 e 5 , podemos observar o estabelecimento de uma solidariedade incomum, demonstrando um alto grau de coesão. No desenvolvimento do CASO 2, a coesão de três componentes do grupo não conseguiu manter o grupo. Por outro lado, a coesão entre os componentes do grupo nos CASOS 3, 4 e 5, talvez tenha sido o elemento mais importante para a permanência do grupo, especialmente no CASO 3

Há ainda a questão da segregação, que de modo geral está ligada à formação de estereótipos. Muito embora, como professor/coordenador do grupo, tenha tentado facilitar meios de comunicação entre os componentes do grupo, pude verificar, no desenvolvimento dos casos apresentados como exemplos, duas situações de segregação em níveis e conseqüências frontalmente diferentes. No CASO 1, por exemplo, apesar da segregação imposta ao aluno D, apesar de minhas tentativas de elaboração, o grupo, possivelmente, com o objetivo de alcançar a realização da tarefa, aceitou a integração do aluno $\mathrm{D}$, esqueceu a história passada e passou a operar com produtividade. No entanto com o grupo do CASO 2, que desde o primeiro momento demonstrou rejeição à aluna $\mathrm{H}$, apesar de minhas tentativas de estabelecer a comunicação entre os componentes do grupo, o processo de segregação foi se desenvolvendo, se intensificando, e culminou por determinar a extinção do grupo. 


\section{de aprendizagem.}

Nesse sentido, este experimento corrobora com a prática proposta por PichonRivière, referente à aplicação e manejo em grupos operativos. Principalmente quanto à conceituação do Esquema Conceitual Referencial Operativo: estou plenamente convencido de que a viabilidade deste experimento somente foi possivel a partir do momento em que como professor/coordenador de grupo pude, efetivamente, compreender a necessidade de minha mobilização como sujeito, de modo a quebrar a estereotipia projetada nos alunos.

Esse incremento de conhecimento, dinâmico e permanente durante o processo dialético que se estabelece na relação ensino aprendizagem, na verdade se configura na única possibilidade de atingir e manter uma freqüência de comunicação entre professor/coordenador e aluno.

Este experimento parece destacar, especialmente, a importância da questão da análise dos vínculos estabelecidos pelos sujeitos, e da teoria dos três $\mathrm{D}$ (depositante, depositário e depositado): se analisarmos os casos apresentados poderemos perceber que a análise de relações vinculares bem caracterizadas, efetivamente, possibilita a compreensão do sujeito. E, para que esse conhecimento implícito, no sujeito, possa ser adquirido é de importância fundamental a facilitação do estabelecimento da comunicação, para a qual a aplicação da teoria dos $3 \mathrm{D}$ mostrou-se de real importância.

A seleção dos casos apresentados neste trabalho pretendeu mostrar a constante dinâmica à qual o ECRO fica submetido.

Nesse contexto, a conduta do professor/coordenador deve considerar três fatores fundamentais:

- O professor coordenador deve mostrar-se a todo momento desapreensivo. A ansiedade do professor pode desenvolver no aluno dificuldades em sua comunicação;

O professor coordenador deve estar receptivo a todo e qualquer tipo de comunicação. A perda de alguma informação - e os alunos estão constantemente se comunicando, verbalmente ou não - pode levar o grupo a encontrar dificuldades em sua mobilização; 
professor/coordenador deve estar preparado para quando necessário
modificar, sem preconceitos, seu ECRO inicial, uma vez que para o
estabelecimento de um ECRO operativo, há que se incorporar todo
aprendizado adquirido no desenvolvimento grupal.

\subsubsection{Quanto à possibilidade concreta da reversão do processo de conflito estabelecido na relação Ensino/Aprendizagem}

Aqui proponho dois enfoques para análise dos resultados obtidos:

\subsubsection{Análise qualitativa}

Se aceitarmos o conceito que assume que a forma de tratar o tema representa o conteúdo normativo da tarefa, então, ao considerar o desenvolvimento dos grupos, que efetivamente se configuraram como grupos operativos, poderemos aceitar a real possibilidade de reversão do conflito entre os sujeitos Aluno, Aprendizagem, Escola/Professor, vértices da relação triangular básica que se estabelece no desenvolvimento do processo ensino aprendizagem.

Desse modo, os resultados obtidos, analisados do ponto de vista de realização da tarefa nos indicam a efetiva possibilidade do quadro de conflito que nos foi mostrado pela pesquisa apresentada no CAPITULO 2.

\subsubsection{Análise quantitativa}

\subsection{Objetivo desta análise}

Para esta análise contatei 32 (trinta e dois) alunos, voluntários, que fizeram parte de nosso experimento principal, e que no momento desta pesquisa ainda estavam vinculados à Escola 2 (mais especificamente, esses alunos, no momento atual, participavam do curso preparatório pré-vestibular oferecido pela Escola 2).

Esses alunos, portanto, embora não tenham respondido, no início de nosso trabalho, ao questionário apresentado no $\operatorname{ANEXO~3,~estão~representados~estatisticamente~no~}$ resultado daquela pesquisa, por se constituírem de indivíduos do mesmo universo estatístico abordado na aplicação inicial daquele questionário.

Consideramos portanto que comparar as respostas desses alunos, que passaram pela dinâmica de trabalho em grupos operativos, com as daqueles alunos que não participaram desse processo pode trazer algum aprendizado. 
Esses 32 alunos (objeto desta discussão), foram convidados a responder ao questionário apresentado no ANEXO 3, e todos aceitaram. Foram informados de que não havia a necessidade de identificar-se, e de que sua participação, ou não, da pesquisa não lhes traria nenhum beneficio ou prejuízo imediato. Esses alunos, evidentemente, conheciam o professor/pesquisador, no entanto não conheciam de antemão o questionário que foi aplicado, e nada lhes foi dito com relação ao objetivo da pesquisa, além de que respondessem às questões propostas apenas com a verdade. A pesquisa foi aplicada por um professor, não envolvido com a pesquisa, e na ausência do professor/pesquisador.

\subsection{O resultado da aplicação do questionário aos alunos}

As respostas dadas pelos alunos às questões apresentadas foram tabuladas e o resultado está apresentado abaixo.

1) Você gosta de sua escola?

$23 \mathrm{Sim}$.

08 Médio.

01 Não.

2) Você tem muitos(as) amigos(as) na sua escola?

$21 \mathrm{Sim}$. 11 Médio.

00 Não.

3) Você gosta de estudar?

$12 \mathrm{Sim}$.

18 Médio.

02 Não.

4) Você acha que a escola é importante para que a pessoa vença na vida?

$10 \mathrm{Sim}$.

12 Médio.

00 Não.

5) Você acha que a escola pode ajudar a que as coisas melhorem em seu país?

$18 \mathrm{Sim}$.

14 Médio.

00 Não.

6) E você... Você acha que pode ajudar a que as coisas melhorem em seu país?

$08 \mathrm{Sim}$.

23 Médio.

01 Não.

7) Você acha que a maioria de seus professores é competente?

$26 \mathrm{Sim}$.

06 Médio.

00 Não.

8) Você acha que a maioria de seus professores se preocupa com você?

$24 \mathrm{Sim}$.

08 Médio.

00 Não. 
9) Você acha que a maioria de seus professores trabalha para que as coisas
melhorem em seu país? 14 Sim.

\section{Médio.}

02 Não.

10) Aponte as 3 (três) piores coisas de uma aula.

Aqui, tomamos a liberdade de relacionar as 5 (cinco) principais queixas (em ordem decrescente de freqüência), além de editar os textos próprios dos alunos.

a) Aulas em que os assuntos abordados não têm ligação com a realidade do aluno;

b) Aulas muito paradas;

c) Aulas muito teóricas;

d) Não compreender os enunciados;

e) Ter que "decorar muitas fórmulas".

6.1.3.2.3. A análise preliminar das respostas ao questionário aplicado aos alunos

Como já dissemos anteriormente, acredito que a análise das respostas apresentadas pelos alunos nos permite uma visão suficientemente clara sobre a imagem que $o$ aluno internaliza de sua relação com os objetos Escola/Professor e Aprendizagem, e que portanto comparar estas respostas com aquelas dadas por alunos que não participaram do processo pode representar um ganho de conhecimento significativo.

Basta um olhar geral sobre as presentes respostas e já sentiremos uma evolução positiva na relação desses alunos com os objetos Escola/Professor e Aprendizagem.

Se observarmos as respostas dadas às questões 1), 2), 3), 4), 5) e 8), parece-nos bastante claro, que a relação do aluno com a escola está bastante modificada em relação ao momento inicial.

Alem disso, as respostas dadas às questões 7), 8), 9) e 10) mostram que o aluno passou, também, a ver o professor de uma forma mais positiva.

Em continuação, as novas respostas dadas às questões 4), 5) e 6) parecem mostrar crescimento na auto estima do aluno.

Ou seja, a "atual" imagem que esses alunos nos mostram é sensivelmente mais positiva que aquela apresentada no CAPÍTULO 2. 
Bem, se considerarmos que esses alunos, embora não individualmente, mas dentro de um enfoque estatístico, são os mesmos abordados pelo questionário inicial (CAPÍTULO 2), e que possivelmente a única ação mobilizadora tenha sido o fato de terem participado do trabalho em grupos operativos, me parece que essa metodologia se apresenta como uma ferramenta efetivamente capaz de modificar positivamente o indivíduo, no sentido de fazer com que esse sujeito possa se deparar com a realidade, e possa se mobilizar de modo a compreender e superar essas dificuldades.

\subsubsection{Conclusão quanto à possibilidade concreta da reversão do processo de conflito estabelecido na relação Ensino/Aprendizagem}

Portanto, a análise dos dados obtidos, tanto a partir do enfoque qualitativo, como quantitativo, nos leva a admitir que a reversão do quadro de conflito, que nós conhecemos, e que pudemos comprovar pela avaliação da respostas dadas pelos alunos ao questionário1 2.1.2., é perfeitamente possível.

No entanto, essa mesma análise parece mostrar que essa reversão depende, de forma significativa, de uma mudança em todos os componentes dessa relação, ou seja: Aluno, Aprendizagem e Escola/Professor; e que a mudança de atitude desses componentes passa pela re-elaboração das imagens estereotipadas projetadas entre e de esses sujeitos.

\subsubsection{Quanto aos fatores que podem influenciar positivamente a "mudança de olhar" entre Aluno, e Escola/Professor.}

Esta experiência me deixou plenamente convencido de que o fator fundamental a ser considerado para o sucesso da mobilização do grupo consiste no manejo adequado, por parte do professor/coordenador, dos grupos operativos - a partir do conceito de que o bloqueio da aprendizagem ou estereotipia por si só corresponde a uma alteração de conduta. Isto implica em elaborar a estereotipia, os esquema referenciais do grupo, e além disso manter o nível ótimo de ansiedade para o aprendizado, uma vez que não existe aprendizado sem ansiedade.

A partir desse conceito é fundamental, preliminarmente, o vivenciar do professor, durante a realização da sessão. Não por ser o único aspecto relevante, mas simplesmente porque a auto-análise, no desenvolvimento do processo, certamente tende a levar o sujeito à diferenciação entre a verdade e a imagem estereotipada. Nesse sentido, o apoio psicológico ao professor seria bem-vindo. 
Meu trabalho, como professor/coordenador, com grupos operativos se constituiu num fator gerador de angustias e ansiedades muito intensas. Isto porque da mesma forma com que o aluno resiste às mudanças, diante de uma nova dinâmica, minha entrada nesse novo mundo de relações e valores, a insegurança provocada ao deparar-me com conflitos novos, ter que suportar a responsabilidade da mobilização dos grupos, constituíram fatores muito dificeis de elaborar.

Além disso, considero importante chamar a atenção para a questão do desgaste físico. Foi uma tarefa extremamente dificil, do ponto de vista físico, levar adiante mais que três grupos em cada sessão. Há também que se considerar, no número de grupos por sessão, a questão da dificuldade de documentação e registro de dados. Portanto a questão do número de grupos por sessão tem importância relevante no desenvolvimento do processo.

É importante ressaltar que, muito embora, o pensar seja espontâneo, é tarefa árdua para o professor/coordenador impedir o seu bloqueio. A identificação destes momentos constituem aspectos básicos para análise e re-elaboração do ECRO, e consequentemente o estabelecimento da espiral dialética necessária para a mobilização do grupo. Está claro, mesmo na bibliografia, que a técnica de grupos operativos somente pode ser aprendida através da experiência pessoal, no entanto nos parece que a fundamentação teórica específica para esse processo seria bem vinda na formação do professor.

Como podemos perceber, ao se comprometer com o modelo de grupos operativos, uma enorme responsabilidade recai sobre o professor/coordenador.

No entanto, da mesma forma que no modelo defendido por Pichon-Rivière que considera um esquema referencial abrangente, que integra elementos novos emergentes do processo que se estabelece na dinâmica grupal acarretando numa libertação do professor/coordenador de seus pré-conceitos, sem o que esse professor/coordenador não será capaz de adequar de forma significativa seu esquema referencial, por outro lado cabe ao professor/coordenador, a função de pesquisar através do experimentar nas sessões de trabalho, através de um processo de testes, acertos e erros, mas claro, isso tudo dentro de um esquema referencial, que deve funcionar a partir de observação.

Portanto pode-se pensar que a conduta do professor/coordenador (apropriando-me da imagem de cone invertido, associada ao ECRO por Pichon-Rivière) deva ser análoga à ação de um individuo que toma a responsabilidade de fazer o cone de ECRO girar, 
110

provocando a precessão de seu eixo, de modo a fazer com que essa agitação externa (a acão do professor/coordenador), leve os implícitos (o vértice do cone) ao explícito (a base do cone). Se a ação do professor/coordenador for insuficiente, há o risco de retornar ao vértice (o implícito), se for demasiada, há o risco de estereotipia (a base do cone). Então, para que venha a ocorrer o processo de entrada do sujeito naquela espiral dialética, que leva do implícito para o explícito, sem o risco de involução ou de estereotipia, é necessário que o professor /coordenador tenha a sensibilidade de agitar o cone continuadamente a na freqüência adequada. $\mathrm{E}$ esse deve ser o maior cuidado do professor/coordenador, em seu trabalho com grupos operativos!

As idéias aqui apresentadas, como afirmamos desde o início deste trabalho, está apoiada na observação do desenvolvimento de 28 grupos de alunos, e tem como objetivo único fornecer algum suporte para a compreensão do conflito Aluno, Aprendizagem e Escola/Professor. 


\section{BIBLIOGRAFIA:}

BACHELAR, Gaston: "A formação do espirito científico: contribuição para uma psicanálise do conhecimento". Contraponto. R. de Janeiro. 1996.

BALDINO, R.R.: "NORMAS DA ASSIMILAÇÃO SOIIDÁRIA". Departamento de Matemática, IGCE, UNESP, Rio Claro. São Paulo.

BALDUINO, AAndreola: "Dinâmica de Grupo: Jogo da vida e didática do futuro". Editora Vozes. R. de Janeiro.1999.

BILEH, V. Y.; MALIK, M. H.: "Development and application of a test on understanding the nature of science". Science Education, 61, pp 559-571. 1977.

BION, W. R.; “Experiencias en Grupos”. Paidos. S. Paulo, 1990.

BLEGER, J.; "Temas de Psicologia; Entrevista e Grupos". Martins Fontes. S. Paulo, 1998.

BOUD, D. J.; DUNN, J.; KENNEDY, T; THORLEY, R: “The aims of science laboratory courses; a survey of students, graduate and practising scientist". European Journal of Science Education, 2, pp 451-458. 1980.

BRANDÃO, C. R. (org.): “Repensando a pesquisa participante”. São Paulo. Brasiliense. Pp 15-50 e 51-81. 1984.

BRANDON, E. P. : “Logic in the laborathory”. School Science Review, 62, pp 762-765. 1981.

DECHERF, Gérard: “Édipo em Grupo”. Artes médicas. Porto Alegre. 1986.

DEWEY, J.: “Democracy and Education". The Free Press, New York. 1916.

DEWEY, J.: "Methods in Science Teaching". Science Education, 29, pp 119-123. 1945.

DRIVER, R.: "Psicologia cognocitiva y esquemas conceptuales de los alumnos". Enseñanza de las Ciencias, 4 (1), pp 3-15. 1986.

ENYEART, BAKER e VANGERLINGEN: "Correlation of inductive and deductive logical reasoning to college physiscs achivement". Journal of Research in Science Teaching, 17, pp 263-267. 1980. 

FREUD, Sigmund: "Totem e Tabú, e outros trabalhos". Imago Editora. R. de Janeiro.
1969.

FREUD, Sigmund: "Além do Princípio do Prazer, Psicologia de Grupo, e outros trabalhos". Imago Editora. R. de Janeiro. 1969.

GIL, D.; PAYA, J.: "Los Trabajos Prácticos de Física y Química y la Metodologia Cientifica". XX Reunión Bienal da la Real Sociedad Española de Química. Catellón.
1984.

GIL, D.: "Tres paradigmas básicos en la enseñanza de las ciencias" . Enseñanza de las Ciencias, vol. 1, pp 26-33. 1983.

HODSON, D.: "Philosophy of science, science and science education". Studies in Science Education, 12, pp 25-57. 1985.

INHELDER, B. ; BOVET, M. ; SINCLAYR, H.: "Aprendizagem e Estruturas do Conhecimento". Saraiva. S. Paulo. 1977.

MILLOT, C.: “Freud, antipedagogo?”. Paidos. Barcelona. 1982.

OGUNNIYI, M. B.; PELIA, M. D.: "Conceptualizations of scientifics concepts, laws and theories held by Kware State, Nigeria, secondary school science teachers". Science Education, 64, pp 591-599. 1980.

OSBORNE, R.; WITTROCK, M.: “ The Generative Learning Model and its Implications for Science Education”. Studies in Science Education, 12, pp 59-87. 1985.

PIAGET, J.: “A equilibração das estruturas cognitivas: $o$ problema central do desenvolvimento". Zahar Editores. R. de Janeiro 1975.

PIAGET, J.: “Epistemologia Genética”. Martins Fontes. S. Paulo. 1990.

PIAGET, J.: “Psicologia e Epistemologia”. Forense Universitária. R. de Janeiro 1978.

PIAGET, J.: “Estudos Sociológicos”. Forense Universitária. R. de Janeiro. 1973.

PIAGET, J.: “Para onde vai a educação”. José Olímpio. R. de Janeiro. 1980.

PIAGET, J. (org): “Logique e connaissance scientifique”. Galimard. Dijon. 1967.

PIAGET, J. et al.: “Fazer e compreender". Melhoramentos. EDUSP. S. Paulo. 1978.

PIAGET, J. et al.: "La tomada de conciencia". Morata. Madrid. 1976.

PICHON-RIVIĖRE, Enrique: “Teoria do Vínculo”. Martins Fontes. S. Paulo, 1998. 
113

PICHON-RIVIÈRE, Enrique: “O Processo Grupal”. Martins Fontes. S. Paulo, 1998.

ROWELL, J. A.; CAWTHRON, E. R. : "Images of science: an empirical study" . European Journal of Science Education, 4, pp 1-10. 1982.

RUBBA, P. A.; HORNER, J. K.; SMITH, J. M. : "A study of two misconceptions about the nature of science among junior high school students". Journal of Research in Science Teaching, 2, pp 221-226. 1981.

SUMMERS, M. K.: "Philosophy of science in the science teacher education curriculum". European Journal of Science Education, 4, pp 1-10. 1982.

SWAIN, R. L.: "Practical objectives. A review". Education in Chemistry, sep 1984, pp 152-154 e 156.

TEIXEIRA, O. P. B.; CARVALHO, A. .M. P.; CAMPOS, G.; CASTOR, R. S.; ESPINOSA, R.; GARRIDO, E.; GOSCIOLA, V.; LABURU, C.E.; NASCIMENTO, L.; SILVA, D.: “FEUSP: Atas de ESNEF”. São Carlos. São Paulo. 1991.

THIOLLENT, Michel: “Metodologia da Pesquisa-Ação”. Cortez Editora. S. Paulo. 1998.

WELLINGTON, J. J.: “What's supposed to happen, Sir?: some problems with discovery learning". School Science Review, 4, pp 19-28. 1974.

ZUÑIGA, R: "La Recherche-Action et le Contrôle du Savoir". Revue Internacionale D'Action Communautaire, 5, pp 35-44. 1981. 
ANEXOS 


\section{ANEXO 1: O TESTE SOCIOMÉTRICO APLICADO AOS ALUNOS}

Tendo em vista que estávamos interessados apenas na detecção de possíveis lideranças atuantes nos grupos, e as possíveis estruturas de subgrupos, propusemos o seguinte teste... O TESTE

Nome:

\section{PERGUNTA 1:}

Em quem você vota para liderar o estudo e debate do tema “. "*?

R.:

\section{PERGUNTA 2:}

Em quem você vota para organizar uma festa?

R.:

* O tema em questão dependia do assunto a ser abordado no curso. 


\section{ANEXO 2: O TESTE DE AVALIAÇÃO dOS CONCEITOS PRIMITIVOS}

Nome

Série:

Idade:

1) No seu dia-a-dia, usamos muitas vezes cubos de gelo para esfriar refrescos, sucos e refrigerantes. Como você explica o fato do gelo tornar as bebidas mais frias?

2) Os recipientes abaixo contêm água com a temperatura indicada. Anote o valor da temperatura da mistura ou separação onde está o ponto de interrogação.

a)

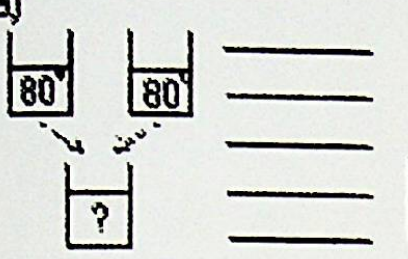

b)

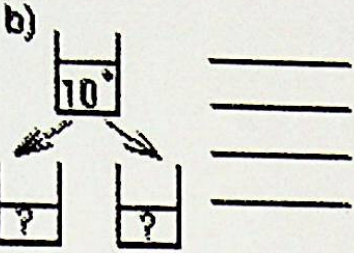

c)
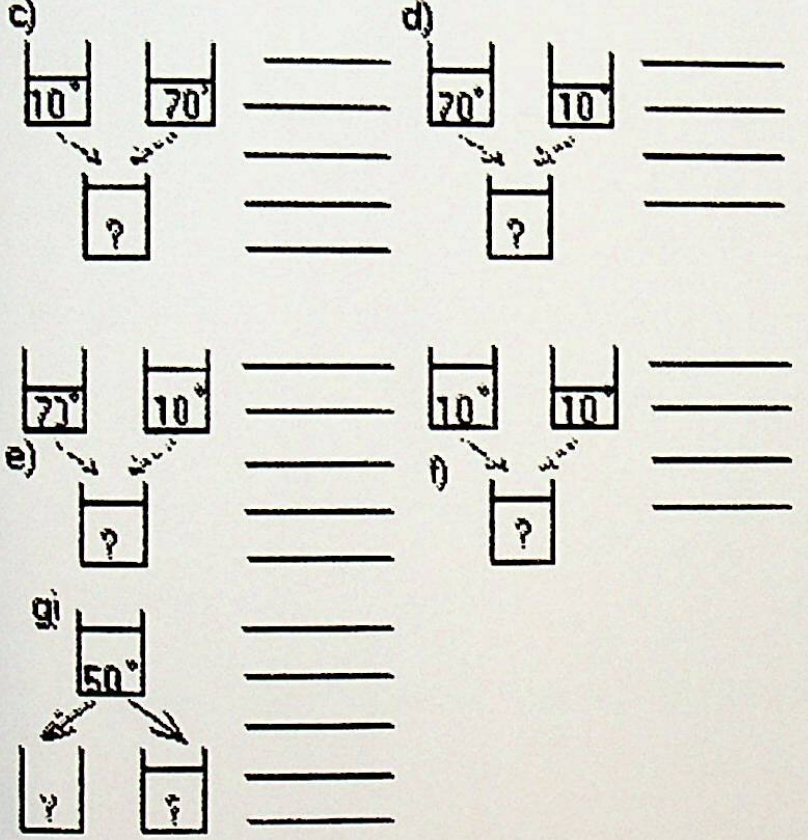

3) Se deixarmos aquecer por 5 minutos as mesmas quantidades de água e óleo as temperaturas irão ser iguais ou diferentes? Como você explica sua escolha?

4) A vovó Donalda tira a torta quente do forno e a coloca na janela. Explique porque ela esfria. 
5) a - Duas bolinhas do mesmo tamanho, porém sendo de vidro e metal, são colocadas em um forno acesso, durante algum tempo. Todas as bolinhas ficarão igualmente quentes
ou não? Explique.

b - O que significa quente para você?

6) Esfregando rapidamente as mãos percebemos que elas esquentam. Explique porque.

7) $\mathrm{O}$ que é calor para você?

8) O que é temperatura para você? 


\section{ANEXO 3: O QUESTIONÁRIO APLICADO AOS ALUNOS}

Os alunos, após receber os esclarecimentos mencionados no CAPITULO 2, receberam em folha de papel simples, sem nenhum tipo de timbre ou marca especifica, as questões abaixo.

Marque um $\mathrm{X}$ ao lado de sua resposta

1) Você gosta de sua escola?

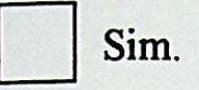
$\square$ Médio.

Não.

2) Você tem muitos(as) amigos(as) na sua escola?
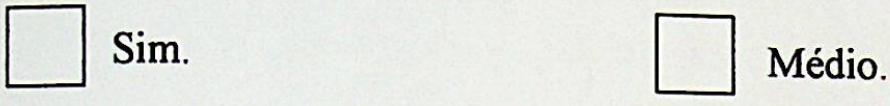

Não.

3) Você gosta de estudar?
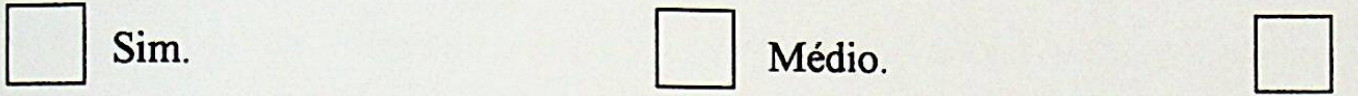

Não.

4) Você acha que a escola é importante para que a pessoa vença na vida?
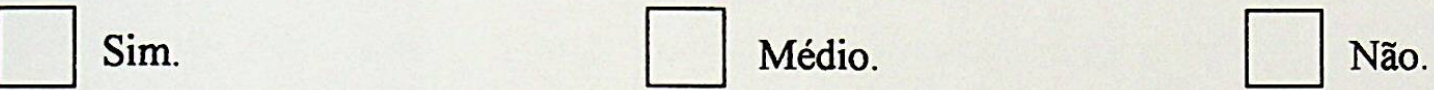

5) Você acha que a escola pode ajudar a que as coisas melhorem em seu país?
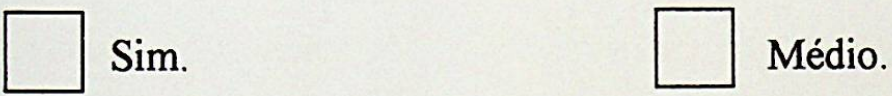

$\square$ Não.

6) E você... Você acha que pode ajudar a que as coisas melhorem em seu país?
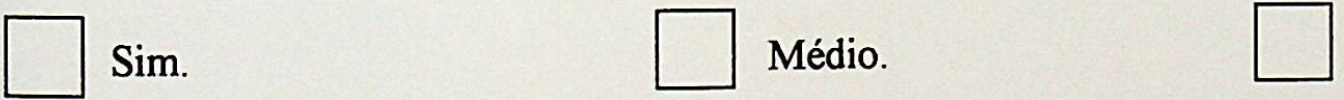

Não.

7) Você acha que a maioria de seus professores é competente?
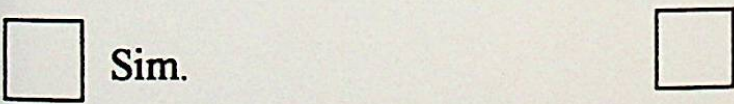

Médio.

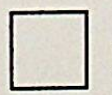

Não.

8) Você acha que a maioria de seus professores se preocupa com você?

$\square$ Sim.
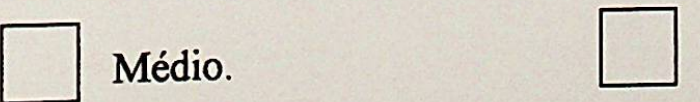

Não.

9) Você acha que a maioria de seus professores trabalha para que as coisas melhorem em seu país?

Sim.

Médio.

Não. 
10) Aponte as 3 (três) piores coisas de uma aula.

a)

b)

c) 


\section{ANEXO 4: O QUESTIONÁRIO APLICADO AOS PROFESSORES}

Da mesma forma que para os alunos, após receber o esclarecimento mencionado no CAPITULO 2, receberam dentro de envelope e em folha de papel, ambos sem nenhum tipo de timbre ou marca especifica, as questões abaixo.

Marque um $\mathrm{X}$ ao lado de sua resposta

1) Você gosta da(s) escola(s) em que trabalha?

$\square$ Sim.

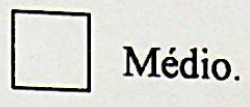

Não.

2) Você gosta de lecionar?

Sim.

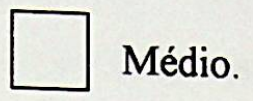

Não.

3) Você acha que a escola é importante para que o aluno vença na vida?

$\square$ Sim.

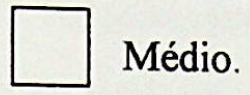

Não.

4) Você acha que a escola atual pode ajudar a que as coisas melhorem em seu país?

$\square$ Sim.

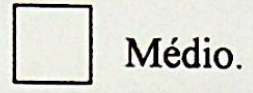

Não.

5) Você acha que a maioria de seus alunos esta interessada em aprender?

$\square$ Sim.

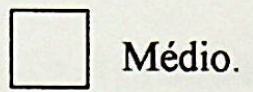

Não.

6) Você acha que a maioria de seus alunos espera trabalhar para que as coisas melhorem em seu país?

Sim.

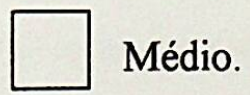

Não.

7) E você... Você acha que pode ajudar a que as coisas melhorem em seu país?

$\square$ Sim.

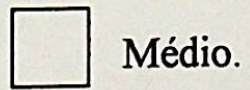

Não.

8) Aponte as 3 (três) piores coisas do ensino atual.

a)

b)

c) 


\section{ANEXO 5: OS FUNDAMENTOS CONSIDERADOS PARA NOSSA ESCOLHA DA
PESQUISA-AÇÃO}

"A pesquisa-ação é inovadora do ponto de vista cientifico quando é inovadora do ponto de vista sociopolitico, isto quer dizer, quando tenta colocar o controle do saber nas mãos dos grupos e das coletividades que expressam uma aprendizagem coletiva tanto na sua tomada de consciência como no seu comprometimento com a ação coletiva." (Zuñiga, 1981)

Os objetivos propostos acima, e suas inegáveis características psicossociais nos levam a optar pela estratégia metodológica da pesquisa-ação definida como:

"um tipo de pesquisa social com base empirica que é concebida e realizada em estrita associação com uma ação ou com a resolução de um problema coletivo e no qual os pesquisadores e os participantes representativos da situação ou do problema estão envolvidos de modo cooperativo ou participativo",

cujas características principais são:

“a) há uma ampla e explicita ação entre pesquisadores e pessoas implicadas na situação investigada;

b) desta interação resulta a ordem de prioridade dos problemas a serem pesquisados $e$ as soluções a serem encaminhadas sob forma de ação concreta;

c) o objeto da investigação não é constituido pelas pessoas e sim pela situação social e pelos diferentes problemas de diferentes naturezas encontrados nessa situação;

d) o objetivo da pesquisa ação consiste em resolver ou, pelo menos, em esclarecer os problemas da situação observada;

e) há, durante o processo, um acompanhamento das decisões, das ações e de toda a atividade intencional dos atores da situação;

f) a pesquisa não se limita a uma forma de ação (risco de ativismo); pretende-se aumentar o conhecimento dos pesquisadores e o conhecimento ou o "nivel de consciência" das pessoas e grupos considerados"; 
g) e ainda, "do ponto de vista cientịfico, a pesquisa-ação é uma proposta metodológica e técnica que oferece subsidios para organizar a pesquisa social aplicada sem os excessos da postura convencional ao nivel da observação, processamento de dados, experimentação, etc. Com ela se introduz uma maior flexibilidade na concepção e na aplicação dos meios de investigação concreta". (Thiollent, 1998)

Nosso objetivo de pesquisa consistia na observação dos processos que se estabeleceram nas relações entre os componentes dos grupos, entre os grupos e entre os pesquisadores e os grupos; também queríamos analisar como esse processo grupal interferia na tomada de consciência e na mudança de atitude desses indivíduos. Para tanto nos pareceu que essa metodologia de pesquisa fosse adequada.

Está claro que, em todas essas relações, todos os participantes tinham algo a fazer e a dizer. Essas ações, índices das relações sociais estruturadas nos grupos, forneceram um perfil da situação dos grupos em tempo real. Isso, certamente deve ser considerado, não apenas na observação dos processos, mas também, principalmente, na re-transformação dos objetivos dos grupos.

Acreditamos que o método de pesquisa-ação é o que permite aos participantes a maior eficiência no "feedback" às situações que se apresentam, principalmente em termos re-polarização de ações de transformação.

Consideramos que os principais diferenciais dessa estratégia (a pesquisa-ação) em nosso contexto foram:

- viabilizar a obtenção de informações sobre a evolução interna, individual (no sujeito), e coletiva (no grupo), perante fatos e/ou problemas concretos, que não seriam detectadas pelos processos convencionais, tendo em vista que sem a participação ativa dos sujeitos da pesquisa, os pesquisadores apenas teriam acesso a "imagens" estáticas ou deformadas dessas informações.

Outro diferencial significativamente vinculado ao modelo de mudança conceitual consistia em...

- não considerar os sujeitos da pesquisa como indivíduos desinteressados ou ignorantes. Dessa forma os preconceitos espontâneos foram levados em conta, pelos pesquisadores, e foi a partir dessa condição que o conhecimento científico foi desenvolvido, ocorrendo um processo de aprendizagem 
significativo entre sujeitos e pesquisadores, pelo aproveitamento da e, agora, quanto às hipóteses...

“... a pesquisa-ação seria um processo diferente, capaz de explorar as situações e problemas para os quais é dificil, senão impossivel, formular hipóteses prévias e relacionadas com um pequeno numero de variáveis precisas, isoláveis e quantificáveis. $\dot{E}$ o caso da pesquisa implicando interação de grupos sociais no qual se manifestam muitas variáveis dentro de um contexto em permanente movimento." (Thiollent, 1998) 


\section{ANEXO 6: $O$ CONTRATO PEDAGÓGICO; CONDIÇÕES PARA O TRABALHO EM GRUPO. O QUE NÃO DEVE ACONTECER!}

- Solicitação de atendimento individual: um elemento se dirige ao professor ou solicita sua presença para falar com ele ou com outro colega, sem haver discutido e estabelecido com seu grupo o que deveria ser perguntado;

- Falta de socialização da dúvida: o grupo decide chamar o professor sem se certificar, antes, de que qualquer um saberá encaminhar a pergunta sobre o que querem saber. Em caso de consenso, cada um deve ser capaz de relatar a conclusão e como o grupo chegou a ela. E em caso de dissenso, cada elemento deve ser capaz de explicar a oposta à sua;

- O grupo perde o problema ou a história do que já fez: o grupo começa a procurar uma solução sem antes formar um consenso sobre o que está procurando ou, quando o professor pergunta: "qual é o problema que vocês estão resolvendo?", um de seus elementos não sabe descrever o problema em suas próprias palavras, não sabe mostrar que formou uma idéia (certa ou errada) sobre o que está sendo pedido (análise qualitativa do problema), ou então não sabe refazer os passos já desenvolvidos;

- Defasagem: um elemento está "esperando" que os outros "terminem" ou todos estão "esperando" por um que está "atrasado", ou dois estão num problema, e outros dois já passaram para outro. É preciso que, a cada instante do trabalho, cada um dos elementos do grupo seja capaz de descrever qual a dificuldade que o grupo está enfrentando. Os mesmos simbolos devem ser usadas para os mesmos significados, $e$ cada elemento deve saber localizar as passagens de seu caderno nos cadernos dos outros. É preciso que estejam pensando juntos, sobre a mesma coisa, o tempo todo. Se um se atrasou acidentalmente, pode "terminar" depois. Se a defasagem de um elemento, para menos ou para mais, é sistemática, isso deve ser comunicado ao professor para providenciar a reorganização dos grupos.

- Falta de fechamento da tarefa: o grupo passou à tarefa seguinte sem ter "fechado" a anterior, isto é, sem ter verificado se todos tinham concluido da mesma maneira (certa ou errada). Ao retornar à tarefa anterior, descobre-se que um elemento tinha opinião 
diferente ou mesmo chegara a um resultado diferente, e não teve espaço ou não quis manifestar isso ao grupo, ou não se preocupou em verificar se os colegas tinham chegado ao resultado que ele julgava certo. Também pode ter ocorrido que o grupo decidiu passar à atividade seguinte sem enfrentar a dificuldade da anterior.

- Interrupç̃̃es e demoras: embora ninguém tivesse chegado atrasado, o grupo só começou a trabalhar efetivamente após muito tempo ou algum elemento do grupo "teve de sair", ou o grupo recebeu um visitante estranho à turma.

- Desconhecimento das regras: revelar desconhecimento desses critérios e dos principios gerais delas decorrentes constitui falta grave. (Baldino, 1989) 


\section{ANEXO 7: OS PERFIS DE ATITUDES DOS COMPONENTES DOS GRUPOS}

Diversos estudos acerca das condutas que os indivíduos assumem nos grupos apontam três categorias de papéis:

a) Papéis centrados na tarefa - são os indivíduos que favorecem a atividade do grupo em relação com seus objetivos:

- Iniciador contribuinte: estimula o grupo abordando idéias e sugestões com relação ao objetivo, ao problema atual, ao procedimento, aos obstáculos por vencer.

- Inquiridor de informação: busca informações para esclarecer as propostas de acordo com sua pertinência, busca fatos em relação direta com o problema discutido.

- Inquiridor de opinião: busca opiniões sobre o que pensam os outros, do que se trata na realidade, etc.

- Informante: procura informações segundo a própria competência ou experiência pessoal.

- Opinante: dá sua opinião pessoal.

- Elaborador: reformula as opiniões e as proposições melhorando sua expressão.

- Coordenador: esclarece e organiza as idéias, as proposições, as atividades.

- Orientador: guia o grupo para a tomada de consciência do seu trabalho, resumindo, elaborando perguntas acerca do que faz, acerca da direção que toma.

- Crítico-avaliador: examina o que o grupo faz em relação às regras.

- Dinamizador: estimula o grupo a tomar decisões.

- Registrador: toma notas para assegurar a memória coletiva do grupo.

b) Papéis de constituição e manutenção do grupo - são os indivíduos que formam, mantém ou reforçam a coesão do grupo:

- Estimulador: manifesta cordialidade, compreende e aceita os pontos de 
vista dos outros.

- Conciliador: trata de estabelecer a harmonia entre os membros do grupo, trata de reduzir as divergências e os desacordos, de acalmar os espíritos.

- Transigente: favorece os compromissos, busca um entendimento quando há um conflito em que se discutem suas idéias ou sua posição, admite erros, abandonando um argumento, dando o primeiro passo para restabelecer a coesão do grupo.

- Guarda-costas: mantém os canais de comunicação abertos, possibilitando a participação dos silenciosos, canalizando os conversadores, propondo fixar a duração das comunicações e estabelecer a ordem para falar.

- Legislador: formula as normas do grupo, indica as pautas que o grupo deve tratar de alcançar para sua própria avaliação.

- Observador-comentarista: registra e analisa a marcha do grupo, observa como funciona e participa no grupo com sua informação.

- Seguidor: aceita sempre as decisões do grupo, voluntária ou passivamente.

c) Papéis individuais - são os indivíduos que constituem um obstáculo para as funções anteriormente citadas, para o progresso do grupo ameaçando sua coesão:

- Agressor: despreza os outros, expressa desacordo com relação a seus atos, seus sentimentos, ataca o grupo ou o que o grupo faça.

- Obstrutor: é sempre do contra. Se opõe sem razão, sempre é contra as decisões adotadas ou sobre os problemas passados.

- Buscador de reconhecimento: trata de atrair a atenção sobre ele, falando de suas proezas pessoais, atuando de maneira forçada, lutando para não ser colocado em uma posição que estima inferior.

- Confessante: aproveita a ocasião de estar em público para expressar seus sentimentos, suas idéias, suas opiniões pessoais, sua relação com o grupo.

- Mundano: enrola o tempo todo, mostra falta de interesse pelo grupo. Cinismo, indolência, jogo e outros comportamentos fora do lugar, são suas formas aparentes.

- Dominador: trata de tomar o poder ou de exercer alguma ascendência 
manipulando o grupo ou a alguns de seus membros. São habituais nele as formas de adulação, as tentativas de obter um "status" superior ou de chamar a atenção dando ordens de maneira autoritária e interrompendo os outros.

- Buscador de ajuda: trata de conseguir ajuda e simpatia de outros participantes ou de todo o grupo confessando sua insegurança, seus estado de confusão, desvalorizando-se de maneira irracional.

- Defensor de interesses especiais: geralmente fica atrapalhado por seus prejuízos e deforma, através deles, as opiniões dos outros. 